\title{
2010 VEHICLE TECHNOLOGIES MARKET REPORT
}

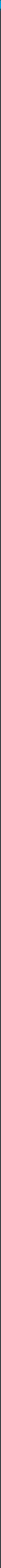

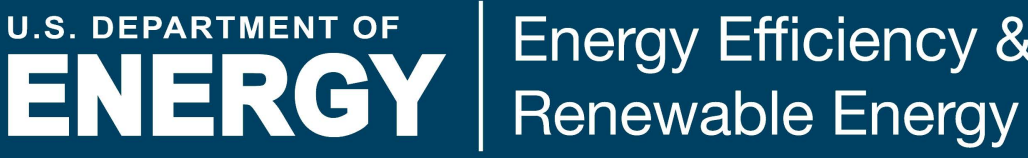


This page intentionally left blank. 


\title{
2010 Vehicle Technologies Market Report
}

\author{
Contents
}

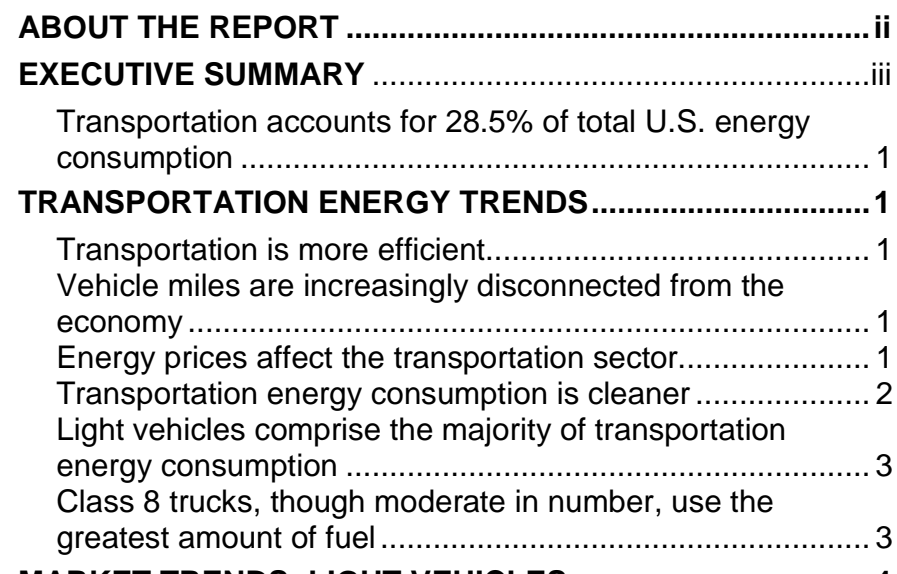

Primary Authors:

Jacob Ward

U.S. Department of Energy

Stacy Davis

Oak Ridge National Laboratory

With Contributions From:

Bill Batten (Eaton), Susan Diegel (ORNL) Vinod Duggal (Cummins), K.G. Duleep (ICF), Richard Smith (ORNL), Skip Yeakel (Volvo)

\author{
Graphic Design: \\ Debbie Bain (ORNL)
}

MARKET TRENDS: LIGHT VEHICLES .................................4

Leading engine suppliers are stable in the United States, but their businesses are growing faster abroad .................. 4 Panasonic dominates the American hybrid vehicle battery market...... 4 GM and Chrysler undergo major restructuring ................... 7 OEM production facilities are concentrated by manufacturer and by state..... 7

Sales volumes have decreased significantly and market shares have shifted among top OEMs .............................. 8 Federal scrappage program created demand for new cars . 9 Major manufacturers have been hard hit by the general economic recession ................................................... 9

Real average vehicle costs are decreasing slightly ............ 9 Light trucks make up 47.5 percent of new vehicle sales.... 11 CAFE has increased for cars and light trucks .................. 11

Most light vehicles gained weight ................................ 13 Vehicles are comprised of more advanced materials ........ 16 More vehicles feature gasoline direct injection (GDi)......... 17 Volkswagen is the only volume seller of light diesels in the United States ............................................................ 17

Flex-fuel vehicles make their way into the population........ 19

Toyota sells the most hybrid electric vehicles .................. 19 HEV incremental price has changed but has not decreased definitively

MARKET TRENDS: HEAVY VEHICLES................................22

Heavy- and medium-truck sales have declined significantly

GM has significantly increased its class 3 truck market penetration 22

Class 4-7 truck sales have declined steadily since 2006 ... 23

Class 8 truck sales dropped $47 \%$ in 2007 and continue to decline

Diesel engine sales have decreased significantly............. 24

Medium and heavy hybrid trucks are on the market ..........24

Energy intensity is affected by different players during manufacturing and operation......

Heavy-truck emissions have been reduced drastically in recent years.... .25

Medium and heavy trucks are more likely to be diesel vehicles.

\section{.}

\section{.}

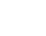

2

3

3

4

4

7

7

8

9

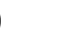

9

1

13

7

17

9

9

2


Truck stop electrification reduces idle fuel consumption ....29 Heavy trucks are increasingly comprised of advanced materials ....................................................................29

Energy performance was relatively steady......................30

Measuring medium and heavy truck energy intensity

requires a freight-based metric .

POLICIES DRIVE THE MARKETS

Corporate average fuel economy rules require more fuel-

efficient vehicles...... 31

The Alternative Motor Fuels Act eases CAFE

requirements for flex-fuel fleets ..................................... 31

Light vehicle emissions standards require clean diesels....31

Ultralow sulfur diesel (ULSD) requirements sparked the

re-emergence of light diesel vehicles ............................... 32

High fuel economy diesel vehicles are subsidized .............. 32

Diesels enjoy economies of scale in Europe..................... 33

Special tax credits incentivize the purchase of HEVs ........34

Federal subsidies discount alternative fuels......................34

Consumers still face limited alternative fuel availability......38

SmartWay encourages efficient heavy truck purchases.....39

Federal subsidies encourage idle reduction technologies.. 40 Inconsistent policies among states send truck

manufacturers mixed signals

The nation's largest commercial fleets include advanced

technology vehicles

COMING UP IN 2011 - 2015

Light-vehicle CAFE standards will become more stringent 43 New heavy-truck fuel consumption and emissions standards will be finalized .44

New heavy-truck technologies will be deployed in response to tighter fuel economy and emissions regulations .44

Electric drive offerings will diversify and expand

significantly

Medium- and heavy-truck sales have suffered through the recession but will recover with the economy .................... 45

Heavy-truck use of advanced fuels will expand, but slowly 45

Natural gas production in the United States will grow ........ 45

Several possibilities exist to reduce heavy-truck engine idling.....

\section{CLASS I FREIGHT RAILROADS}

Seven railroads are considered Class I Railroads ..............48

Locomotive manufacturers have a long history.................48

Old locomotives are still in service ................................... 49

New locomotives on the tracks ....................................... 49

Covered hoppers and tank cars carry the goods ...............49

Average cost of a new freight car is $\$ 95,000 \ldots \ldots \ldots \ldots \ldots \ldots . . . . . .50$

Railroad fuel efficiency is improving ................................51

Ultralow sulfur diesel makes a difference.........................51

Tier 3 and Tier 4 Locomotive emission standards are set.. 51

Rail accounts for less than $3 \%$ of transportation

greenhouse gas emissions ........................................ 51

Future technologies for locomotives ...............................53

Deregulation of the railroad industry has been successful. 53

Traffic density has increased for most Class I Railroads....53

Average railcar capacity is expanding ..............................5 53

Productivity of Class I Railroads is at an all-time high........54

SUMMARY .54

\section{About the Report}

In the past five years, vehicle technologies have advanced on a number of fronts: power-train systems have become more energy efficient, materials have become more lightweight, fuels are burned more cleanly, and new hybrid electric systems reduce the need for traditional petroleum-fueled propulsion. This report documents the trends in market drivers, new vehicles, and component suppliers.

This report is supported by the U.S. Department of Energy's (DOE's) Vehicle Technologies Program, which develops energy-efficient and environmentally friendly highway transportation technologies that will reduce use of petroleum in the United States. The long-term aim is to develop "leap frog" technologies that will provide Americans with greater freedom of mobility and energy security, while lowering costs and reducing impacts on the environment.

\begin{tabular}{|ll|}
\hline & \multicolumn{1}{c|}{ Acronyms } \\
AMFA & Alternative Motor Fuels Act \\
CAFE & Corporate Average Fuel Economy \\
CNG & Compressed Natural Gas \\
CO & Carbon Monoxide \\
CO 2 & Carbon Dioxide \\
CVT & Continuously Variable Transmission \\
CHR & Chrysler \\
DCC & DaimlerChrysler \\
DISI & Direct Injection Spark Ignition \\
DOE & U.S. Department of Energy \\
EEA & Energy and Environmental Analysis \\
EPA & Environmental Protection Agency \\
FFV & Flex-Fuel Vehicles \\
FHWA & Federal Highway Administration \\
FMC & Ford Motor Company \\
GDi & Gasoline Direct Injection \\
GDP & Gross Domestic Product \\
GE & General Electric \\
GM & General Motors \\
GMC & General Motors Corporation \\
GVWR & Gross Vehicle Weight Rating \\
HC & Hydrocarbons \\
HEV & Hybrid Electric Vehicle \\
HON & Honda \\
HVAC & Heating, Ventilation, and Air Conditioning \\
LCF & Long Carbon Fiber \\
LCV & Longer Combination Vehicles \\
LNG & Liquefied Natural Gas \\
LPG & Liquefied Petroleum Gas \\
MPG & Miles Per Gallon \\
MY & Model Year \\
NHTSA & National Highway Traffic Safety Administration \\
NIMH & Nickel-Metal Hydride Battery \\
NIS & Nissan \\
NOx & Nitrogen Oxides \\
OEM & Original Equipment Manufacturer \\
ORNL & Oak Ridge National Laboratory \\
PM & Particulate Matter \\
R\&D & Research and Development \\
SCR & Selective Catalytic Reduction \\
SUV & Sport Utility Vehicle \\
TOY & Toyota \\
ULSD & Ultralow Sulfur Diesel \\
U.S. & United States \\
VMT & Vehicle Miles Traveled \\
VW & Volkswagen \\
$\Delta$ & Change \\
\hline &
\end{tabular}


The bankruptcy of two American manufacturers rocked the automotive world in 2009. Chrysler filed for bankruptcy in April, with General Motors following in June of that year. Both manufacturers emerged quickly from bankruptcy, with help from the Federal government. Chrysler (CHR) merged with Fiat (Fabbrica Italiana Automobili Torino) SpA and General Motors cancelled or spun-off several brands, including Pontiac, Hummer, Saturn, and Saab.

The economic downturn that began in 2008 continued into 2009, with consumers continuing to forgo purchases of new light, medium, and heavy vehicles. This caused even further declines in vehicle sales, despite a Federal government effort that created a surge of light vehicle purchases in the summer of 2009. Energy consumed by the transportation sector decreased for the second year in a row as vehicle miles of travel fell just below the 2008 level.

Despite the contraction in the industry in 2008 and 2009 , the automotive industry is predicted to grow as the U.S. economy slowly expands in 2010. As manufacturers increase production, the movement of commodities will grow as well as demand for passenger mobility. Energy Information Administration projections show increases in the number of vehicles, number of passenger-miles traveled and amount of goods shipped.

With the exception of 2008 and 2009, the transportation sector's energy consumption has generally increased during the past two decades (Figure ES-1). This increase is primarily driven by increasing vehicle miles traveled-more people are traveling more miles, and more goods are being shipped. The increase in energy consumption is less than the increase in mobility, due to an increase in the efficiency of the movement of goods. The stock of light vehicles on the road is also more efficient than five years ago. And mobility is cleaner: Light-, medium-, and heavy-vehicle emissions have decreased significantly during the past five years, thanks to new emissions regulations and the technologies to achieve them.

\section{Figure ES-1. Transportation Energy Consumption}

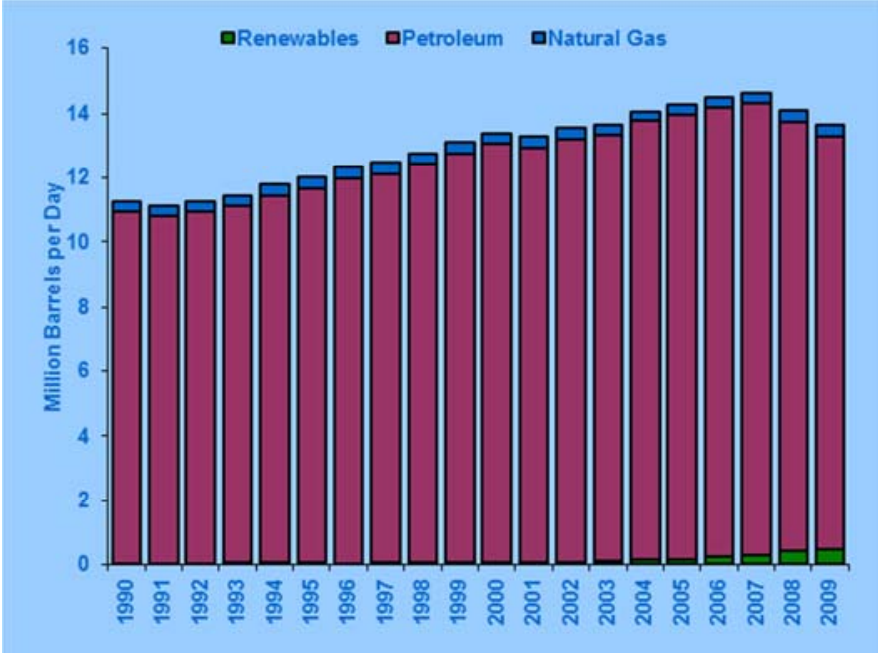

\section{Source: EIA, Monthly Energy Review}

Vehicle sales figures have decreased significantly in the past three years for both the light vehicles that most Americans used for daily driving, and the medium and heavy trucks used for commercial purposes as well as shipping (Figure ES-2). This steep decline in vehicle purchases comes at a time when the entire country is experiencing an economic downturn. The transportation industry was hit especially hard in 2008, when economic problems were compounded by an oil shock.

Petroleum fuel prices recovered in 2009 from the late 2008 price plunge, and the price of a gallon of gasoline stayed near $\$ 2.00$ per gallon in the first half of the year and near $\$ 2.60 /$ gallon in the last half of 2009 .

New cars and light trucks today are increasingly more energy efficient than cars and light trucks were five years

Figure ES-2. Vehicle Sales

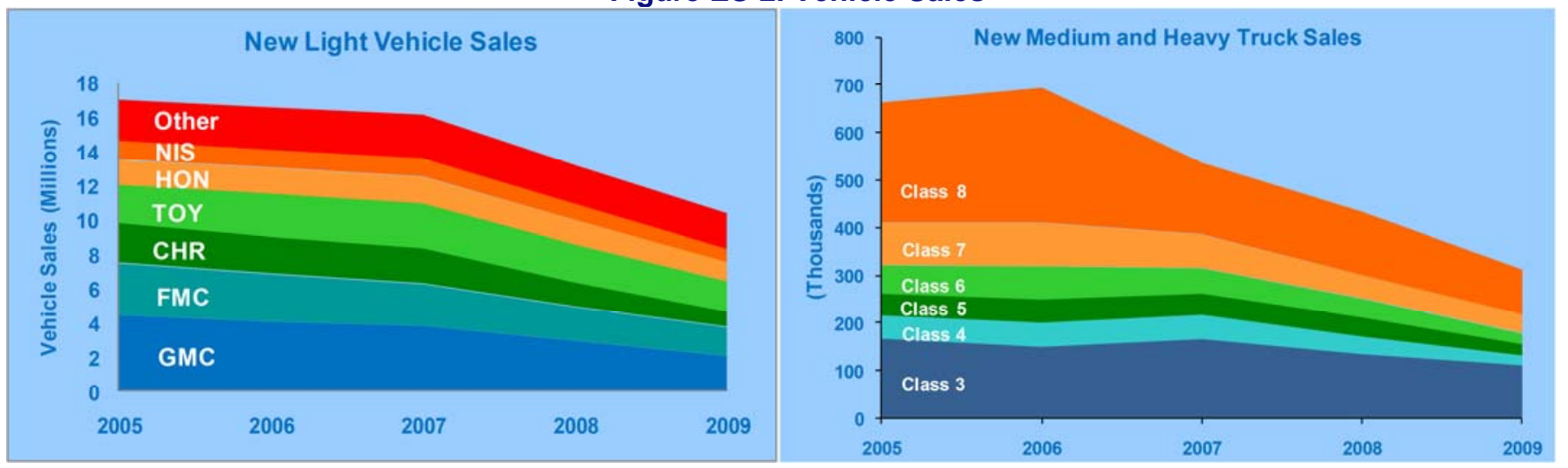


ago. However, because consumers have preferred light trucks over cars in recent years, the combined Corporate Average Fuel Economy (CAFE) for the entire U.S. fleet of both cars and light trucks was not improving much until recently (Figure ES-3). From 2005 to 2009, the CAFE for cars rose $7.6 \%$, and for light trucks rose $11.3 \%$. Light trucks are, on average, less fuel efficient than cars.

\section{Figure ES-3. Corporate Average Fuel Economy}

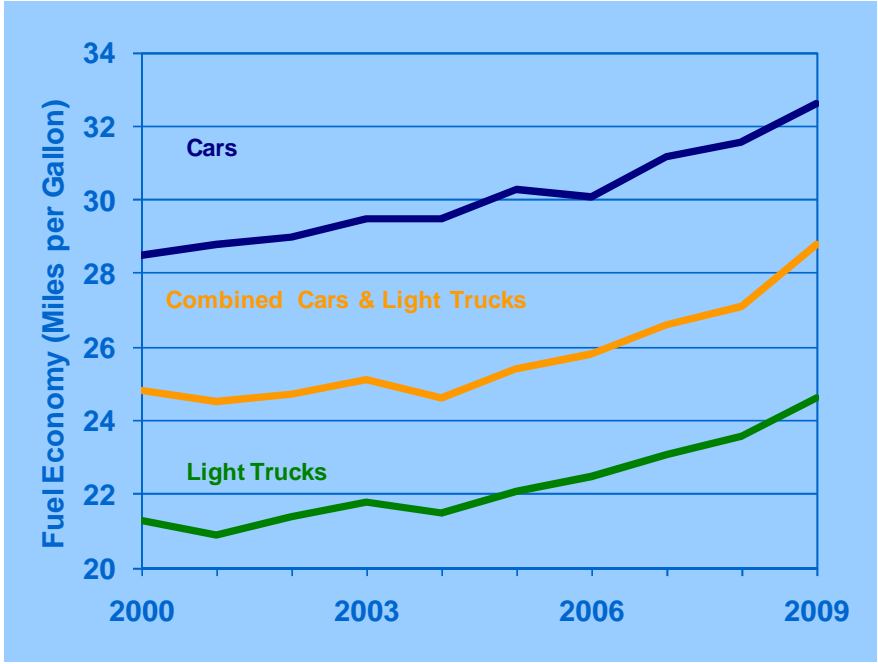

Source: NHTSA, Summary of Fuel Economy Performance

The reduction in emissions for medium and heavy vehicles is an important trend. Since 2002, the Environmental Protection Agency (EPA) has required that diesel vehicles reduce nitrogen oxide ( $\mathrm{NO}_{\mathrm{x}}$ ) emissions by more than $50 \%$ (from 2.5 to $1.2 \mathrm{~g} / \mathrm{HP}-\mathrm{hr}$ ) and particulate matter (PM) emissions by $90 \%$ (from $0.1 \mathrm{~g} / \mathrm{HP}-\mathrm{hr}$ to 0.01 g/HP-hr) (Figure ES-4). Medium- and heavy-truck manufacturers have consistently met these requirements on time, and without significantly sacrificing vehicles' performance characteristics.

\section{Figure ES-4. Diesel Emission Regulations}

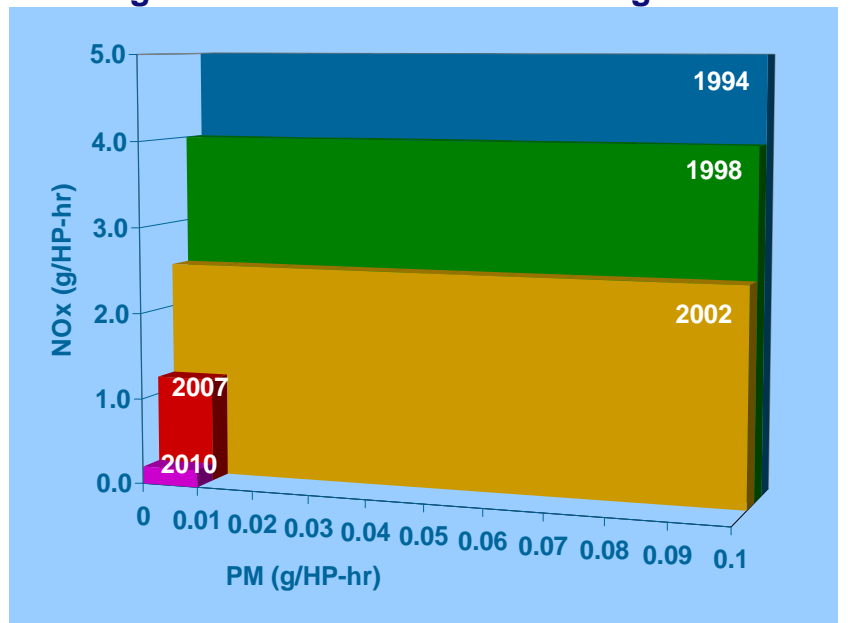

Source: $E P A$

The next several years promise to bring increased fuel efficiency to all on-highway vehicles. Light-vehicle fuel economy will increase by $40 \%$ by 2030 due to more stringent fuel economy standards required by the Energy Independence and Security Act of 2007. The National Highway Transportation Safety Administration and EPA have jointly proposed fuel economy standards and emission standards for medium and heavy vehicles.

In addition to the highway vehicles already mentioned, this year's Market Report includes facts about freight rail. The seven Class I railroads move freight over a network of more than 94.000 road-miles, not including parallel tracks at sidings and yards. Average railcar capacity has grown to 100 tons and productivity for the railroads, measured as revenue ton-miles per employee-hour, has increased $10 \%$ from 2004 to 2008 . The freight railroads are gaining in fuel efficiency; the revenue ton-miles per gallon has increased by $11.5 \%$ (see Figure ES-5). The new hybrid diesel-electric locomotives in development, along with start/stop technologies to reduce engine idle time, will help the rail industry to continue fuel efficiency improvement.

\section{Figure ES-5. Class I Railroads Revenue Ton-Miles} per Gallon of Fuel Consumed

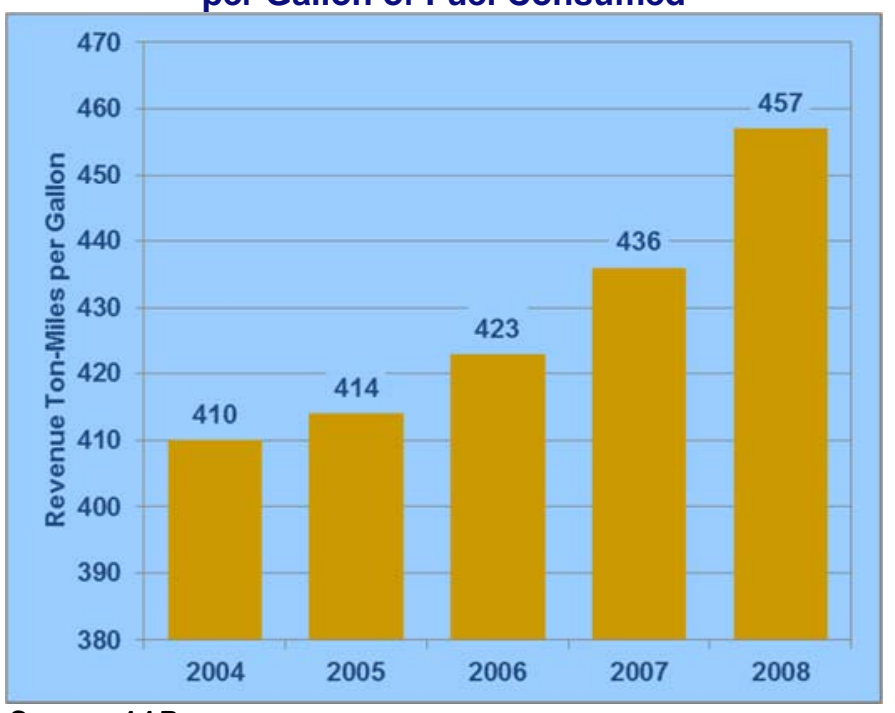

Source: $A A R$

This report details the major trends in transportation energy mentioned here, as well as the underlying trends that caused them. The report opens with a summary of the economic sector, including sector-wide energy consumption trends. The second section includes a discussion on light vehicles, and the third section discusses heavy vehicles. The fourth section discusses the policies that shape the transportation sector, and the fifth section makes projections about what will happen in the highway sector in the next five years. A section on the freight rail industry completes the report. 


\section{Transportation Energy Trends}

\section{Transportation accounts for $28.5 \%$ of total U.S. energy consumption}

In 2009, the transportation sector used 27 quads of energy, which is $28.5 \%$ of total U.S. energy use (Figure 1). Nearly all of the energy consumed in this sector is petroleum (94\%), with small amounts of renewable fuels $(3 \%)$ and natural gas (3\%). With the future use of plug-in hybrids and electric vehicles, transportation will begin to use electric utility resources. The electric-utility sector draws on the widest range of sources and uses only a small amount of petroleum. The energy sources have not changed much during the past five years, although renewable fuel use has grown slightly in each sector.

\section{Figure 1. U.S. Energy Sector and Energy Source,} 2008

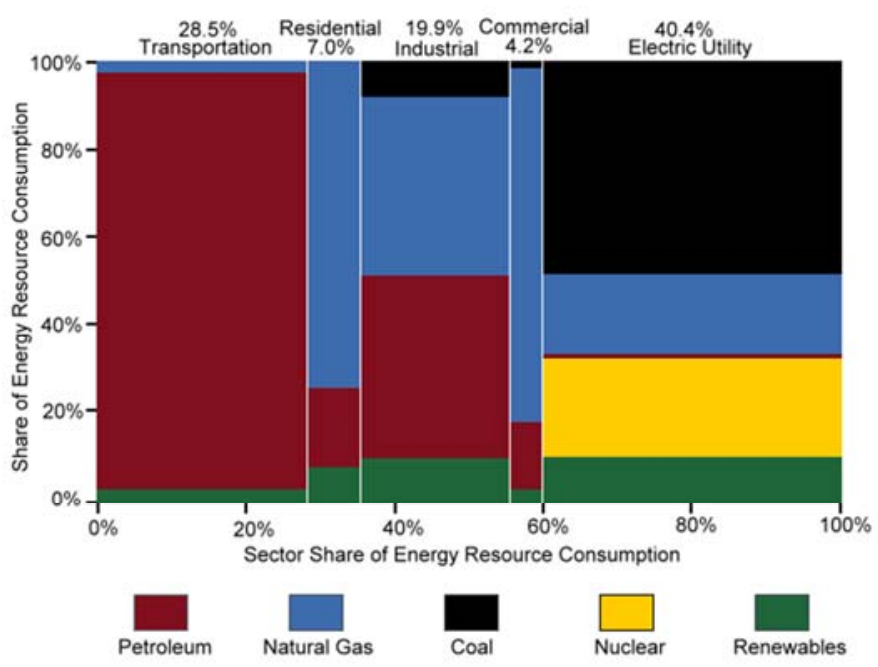

Source: EIA, Monthly Energy Review

\section{Transportation is more efficient}

The number of miles driven on our nation's highways has generally been growing during the past three decades, and energy use has grown with it. However, due to advanced engines, materials, and other vehicle technologies, the amount of fuel used per mile has declined from 1970 (Figure 2). The gallons per mile held steady from the early 1990s to 2008, showing that the fuel economy for new vehicles was stagnant during this period.
Figure 2. Fuel Use per Mile

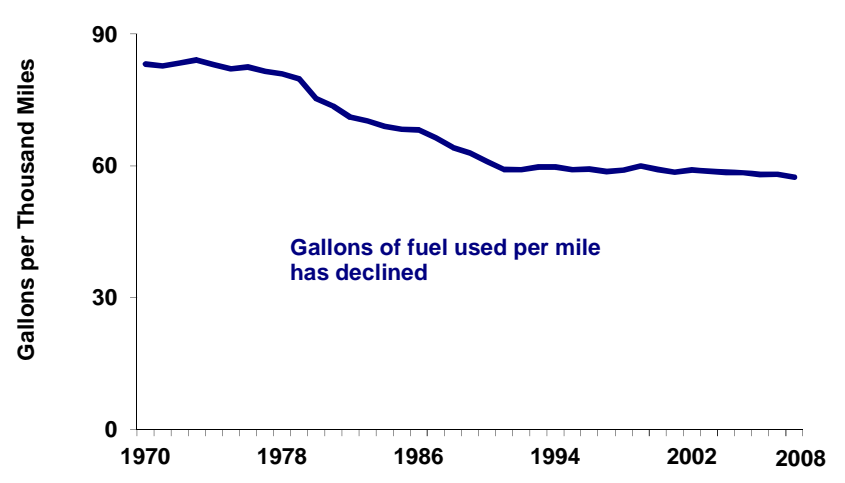

Source: FHWA, Highway Statistics 2008, Table VM-1 and previous editions of the report.

\section{Vehicle miles are increasingly disconnected from the economy}

From 1960 to 1998, the growth in vehicle miles of travel (VMT) closely followed the growth in the U.S. Gross Domestic Product (GDP) (Figure 3). Since 1998, however, the growth in VMT has slowed and has not kept up with the growth in GDP. Like the transportation sector's energy use, VMT declined from 2007 to 2009.

Figure 3. Relationship of VMT and GDP

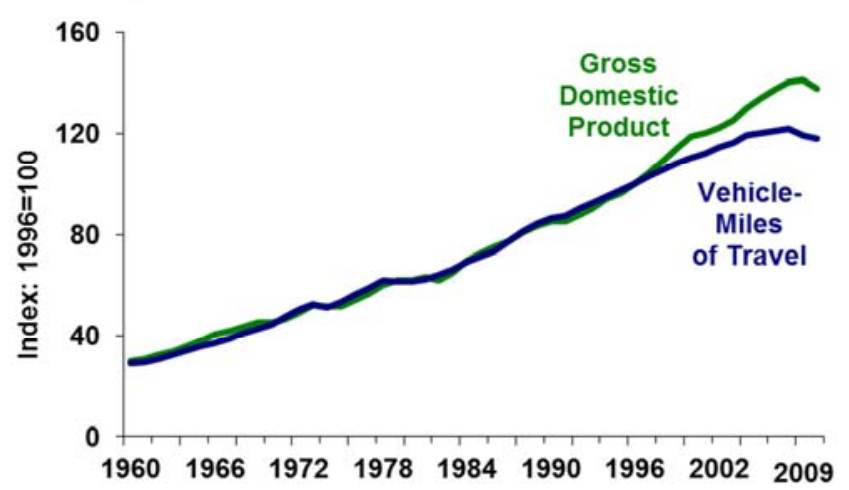

Source: BEA, Survey of Current Business and FHWA, Highway Statistics

\section{Energy prices affect the transportation sector}

The prices of gasoline and diesel fuel affect the transportation sector in many ways. For example, price can impact the number of miles driven in a year, and affect the choices consumers make when purchasing vehicles. The price of gasoline rose dramatically from 2005 to 2008, then fell to near 2005-levels again in 2009; from an annual average of $\$ 2.27$ per gallon in 2005 to $\$ 3.25$ in 2008 , and back to $\$ 2.35$ in 2009 (Figure 4). Diesel fuel prices rose even higher than gasoline in 2008 ( $\$ 3.80$ per gallon), but 
fell to $\$ 2.47$ per gallon in 2009 . The effects of these sharp changes in fuel prices are seen throughout this report in the areas of energy use, VMT, and vehicle sales.

Figure 4. Annual Average Price of Gasoline and Diesel Fuel

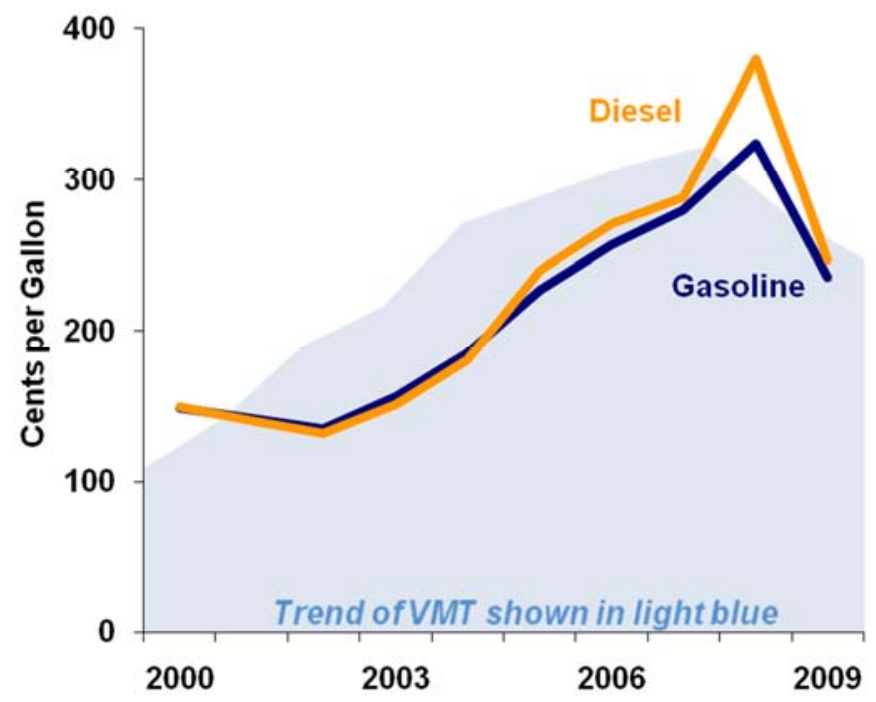

Source: EIA, Petroleum Navigator

Historically, the price of diesel fuel has been lower than the price of gasoline. In 2005, however, that trend changed and diesel fuel became the more expensive of the two. In 2009, the difference between them was 11 cents per gallon.

\section{Transportation energy consumption is cleaner}

Growth in VMT not only equates to higher energy use, but typically means higher emissions coming from the transportation sector. However, due to improvements in vehicle emission technology, the total amount of pollutants emitted has declined (Figure 5). From 1990 to 2008, the emission totals for the transportation sector declined for each of the criteria air pollutants tracked by the EPA carbon monoxide (CO) emissions dropped by $57 \%$.
Figure 5. Transportation Pollutant Emissions

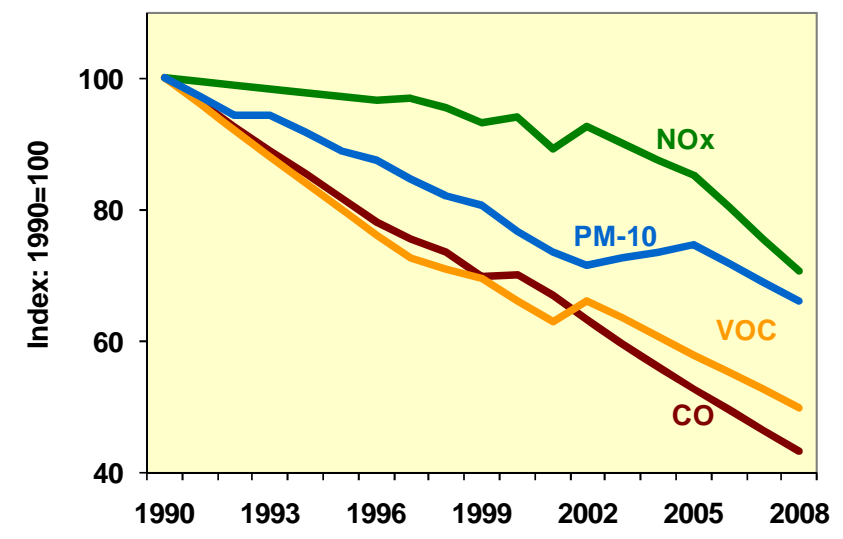

Source: EPA, National Emission Inventory

Carbon dioxide $\left(\mathrm{CO}_{2}\right)$ emissions in the transportation sector have grown from 1,489 million metric tons (MMT) in 1990 to 1,709 in 2008 - a 20\% increase (Figure 6). Much of the increase was due to increases in the amount of $\mathrm{CO}_{2}$ emissions from highway vehicles. However, the $\mathrm{CO}_{2}$ emissions per highway vehicle mile improved by $12 \%$ (Table 1).

Figure 6. Transportation $\mathrm{CO}_{2}$ Emissions

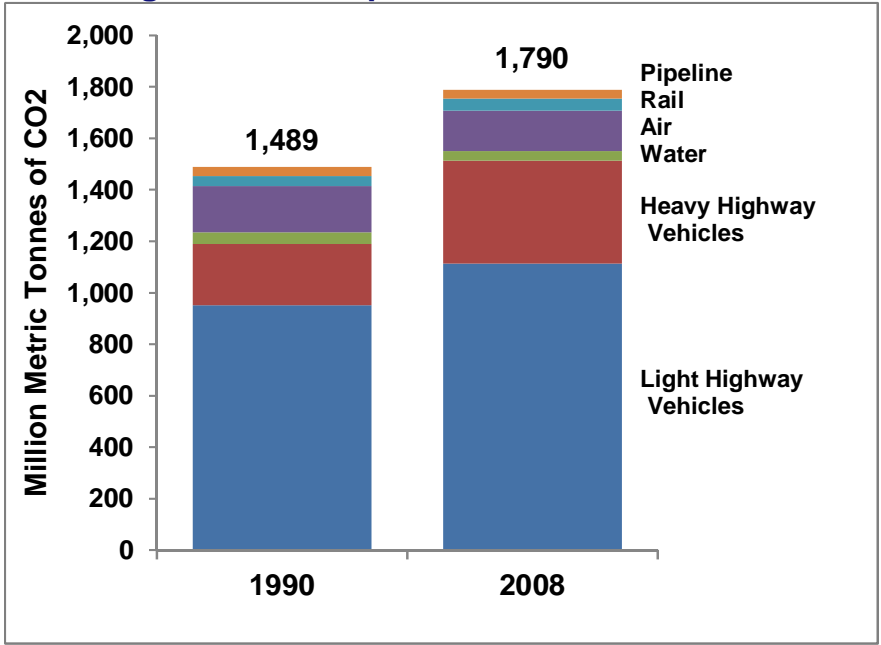

Source: EPA, Inventory of U.S. Greenhouse Gas Emissions and Sinks: 1990-2008, Table 3-12, April 2010.

Table 1. Metric Tons of $\mathrm{CO}_{2}$ per Highway Vehicle Mile

\begin{tabular}{|l|c|c|c|}
\hline & 1990 & 2008 & $18-y r ~$ \\
\hline $\begin{array}{l}\text { Carbon } \\
\text { Dioxide }\end{array}$ & 0.74 & 0.65 & $-12 \%$ \\
\hline
\end{tabular}

Sources: EIA, Emissions of Greenhouse Gases in the United States, 2008, and FHWA Highway Statistics 2008 


\section{Light vehicles comprise the majority of transportation energy consumption}

Light vehicles consume the majority of the energy used by the transportation sector and are predicted to continue that trend, according to the EIA Annual Energy Outlook (Figure 7). The proportion of energy consumption shown in Figure 6 has been fairly constant for the past five years, but the growth of light truck petroleum use is evident when looking at the series history. Beginning in 2005, the United States produced only enough petroleum to meet the energy needs of cars and light trucks. With conventional sources of petroleum (solid black line), the petroleum used by cars and light trucks is expected to outgrow U.S. production.

\section{Figure 7. Transportation Petroleum Use by Mode}

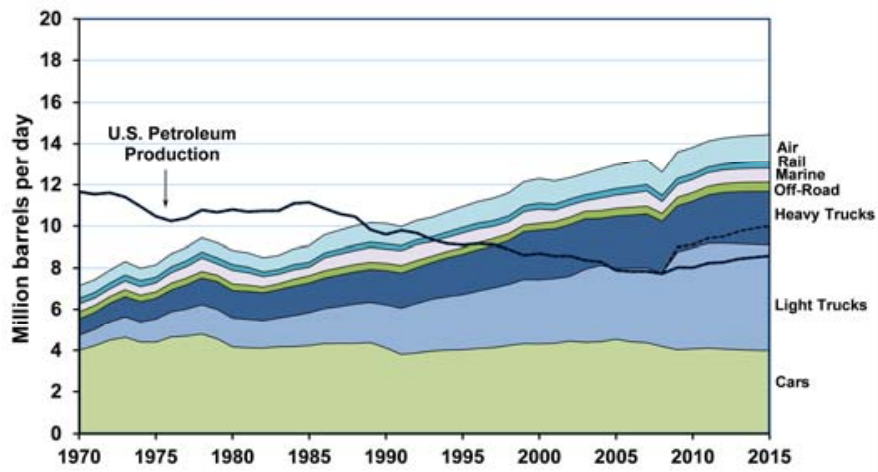

Note: The U.S. Production has two lines after 2005. The solid line is conventional sources of petroleum, including crude oil, natural gas plant liquids, and refinery gains. The dashed line adds in other nonpetroleum sources, including ethanol, biomass, liquids from coal, other blending components, other hydrocarbons, and ethers. The sharp increase in values between 2007 and 2008 are the result of the data change from historical to projected values.

Source: Historical - ORNL, Transportation Energy Data Book: Edition 29. Projections- EIA Annual Energy Outlook 2010.

\section{Class 8 trucks, though moderate in number, use the greatest amount of fuel}

Class 8 trucks comprise only $42 \%$ of the heavyand medium-truck fleet, but they account for $78 \%$ of the fuel consumed by medium and heavy trucks (Figure 8). Class 8 trucks carry the largest loads, which require the greatest energy expenditure per mile. Additionally, class 8 trucks, on average, tend to travel the longest distance: nearly 100,000 miles annually.

Figure 8. Medium and Heavy Truck Fleet Composition (left) and Energy Usage (right)
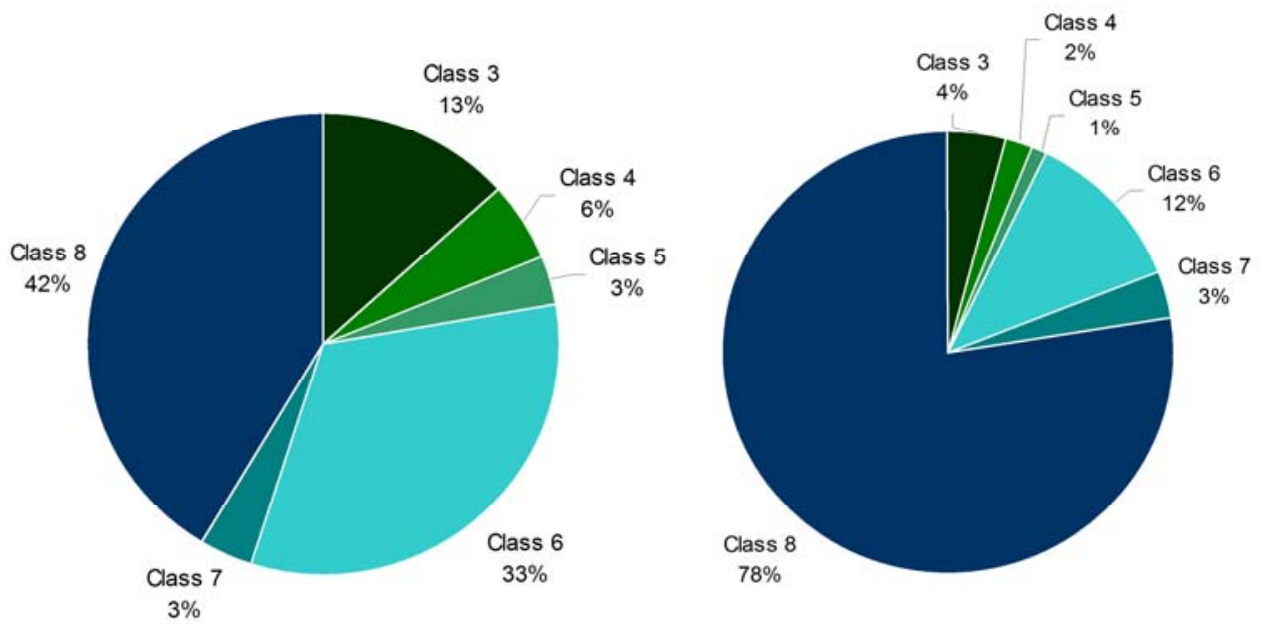

Source: ORNL, Transportation Energy Data Book 


\section{Market Trends: Light Vehicles}

\section{Leading engine suppliers are stable in the United States, but their businesses are growing faster abroad}

Of the top 100 global suppliers, the two of the top three specializing in engines in 2005 are also the top suppliers in 2009 (Table 2). Magna International discontinued the production of engines in 2007. HyundaiWIA Corp. (a Hyundai subsidiary) joined the engine suppliers in 2009. Total company sales increased slightly for Cummins from 2005 to 2009, but declined for Navistar International. It is worth noting that the portion of sales in the United States has decreased, suggesting that growth for these suppliers abroad is outpacing U.S. growth. Light vehicle engine manufacturers are not included in this list, as their production is tabulated as an Original Equipment
Manufacturer (OEM), the metric for which is vehicles manufactured, rather than an engine supplier.

Of the top 100 global engine component suppliers, seven companies from 2005 are among the top in 2009. Total company sales shifted for many suppliers, and ranks shifted accordingly. As in the case of engine suppliers, it is worth noting that the portion of sales in the United States has decreased in all cases, again suggesting that growth for these suppliers abroad is outpacing U.S. growth.

\section{Panasonic dominates the American hybrid vehicle battery market}

In December 2008, Panasonic (the top battery manufacturer in terms of sales volumes for automotive hybrid use) acquired Sanyo, the second-ranked manufacturer (Figure 9, Tables 3 and 4). Sanyo Electric, however, has been maintained as a subsidiary, thus the

Table 2. Leading Suppliers in Engines and Engine Components, Excluding OEMs

\begin{tabular}{|c|c|c|c|c|c|}
\hline \multicolumn{6}{|c|}{ Engines } \\
\hline \multicolumn{3}{|c|}{2005} & \multicolumn{3}{|c|}{2009} \\
\hline Company & $\begin{array}{c}\text { Total U.S. } \\
\text { Sales (Mil\$) }\end{array}$ & $\begin{array}{c}\text { U.S. \% of } \\
\text { Global Sales }\end{array}$ & Company & $\begin{array}{c}\text { Total U.S. } \\
\text { Sales (Mil\$) }\end{array}$ & $\begin{array}{c}\text { U.S. \% of } \\
\text { Global } \\
\text { Sales }\end{array}$ \\
\hline Magna International Inc. & $12,768.0$ & $(56 \%)$ & Cummins Inc. & $2,513.3$ & $(51 \%$ \\
\hline Cummins Engine Co. & $2,363.8$ & $(63 \%)$ & Navistar International & $1,883.0$ & $(70 \%)$ \\
\hline Navistar International & $2,776.1$ & $(85 \%)$ & Hyundai-WIA Corp. & 19.1 & $(1 \%)$ \\
\hline
\end{tabular}

\begin{tabular}{|c|c|c|c|c|c|}
\hline \multicolumn{6}{|c|}{ Engine Components } \\
\hline \multicolumn{3}{|c|}{2005} & \multicolumn{3}{|l|}{2009} \\
\hline Company & $\begin{array}{c}\text { Total U.S. } \\
\text { Sales (Mil\$) }\end{array}$ & $\begin{array}{c}\text { U.S. \% of } \\
\text { Global } \\
\text { Sales }\end{array}$ & Company & $\begin{array}{c}\text { Total U.S. } \\
\text { Sales (Mil\$) }\end{array}$ & $\begin{array}{c}\text { U.S. \% of } \\
\text { Global } \\
\text { Sales }\end{array}$ \\
\hline Delphi Corp. & $16,037.4$ & $(71 \%)$ & Delphi Corp. & $3,761.6$ & $(32 \%)$ \\
\hline Magna International Inc. & $12,768.0$ & $(56 \%)$ & TRW Automotive Inc. & $3,016.0$ & $(26 \%)$ \\
\hline Dana Corp. & $5,424.9$ & $(63 \%)$ & Magna International, Inc. & $2,952.4$ & $(32 \%)$ \\
\hline TRW Automotive Inc. & $4,455.9$ & $(38 \%)$ & Aisin Seiki Co. & $2,470.2$ & $(12 \%)$ \\
\hline Aisin Seiki Co. & $3,223.6$ & $(18 \%)$ & Benteler Automobiltechnik GmbH & $1,902.4$ & $(29 \%)$ \\
\hline BorgWarner Inc. & $1,884.7$ & $(43 \%)$ & Hitachi Automotive Systems Ltd. & $1,312.8$ & $(20 \%)$ \\
\hline Hitachi Ltd. Automotive Systems & $1,484.2$ & $(29 \%)$ & BorgWarner Inc. & $1,109.4$ & $(28 \%)$ \\
\hline CalsonicKansei Corp. & $1,419.9$ & $(22 \%)$ & CalsonicKansei Corp. & $1,055.7$ & $(17 \%)$ \\
\hline Benteler Automobiltechnik GmbH & $1,269.0$ & $(27 \%)$ & Nemak & $1,052.5$ & $(54 \%)$ \\
\hline Timken Co. & $1,196.6$ & $(72 \%)$ & Eaton Corp. & 860.3 & $(70 \%)$ \\
\hline Behr GmbH \& Co. & 874.0 & $(23 \%)$ & Behr GmbH & 756.0 & $(20 \%)$ \\
\hline Mitsubishi Electric Corp. & 681.6 & $(20 \%)$ & Schaeffler Group & 684.0 & $(18 \%)$ \\
\hline Kolbenschmidt Pierburg AG & 360.0 & $(15 \%)$ & Mitsubishi Electric Corp. & 414.5 & $(15 \%)$ \\
\hline \multirow[t]{2}{*}{ Magneti Marelli Holding S.p.A. } & 270.0 & $(6 \%)$ & CIE Automotive S.A. & 289.6 & $(18 \%)$ \\
\hline & & & LG Chem Ltd. & 130.8 & $(1 \%)$ \\
\hline
\end{tabular}


Sanyo brand name has continued. Cobasys, which produced batteries for General Motors, was sold in 2009 to SB Li Motive, LLC - a battery joint venture formed by Bosch and Samsung. For the all-electric Leaf which is coming in MY 2011, Nissan plans to use a lithium-ion battery made by NEC.

From a technical standpoint, the characteristics of batteries and electric-drive systems have improved between 2005 and 2009. Performance has improved as battery internal resistance lowers, and power electronics and motors achieve slight efficiency gains. Batteries are either decreasing in size or producing more power or energy for the same weight. Reliability has not been an issue so far, because both batteries and electric drive systems have shown the durability required to perform in an automotive environment.

Only two of the top 100 global suppliers (Johnson Controls and Panasonic) have manufactured batteries over the past five years (Table 5). Johnson Controls manufactures lead-acid batteries, which are not relevant for HEV-specific applications; Panasonic has manufactured $\mathrm{NiMH}$ batteries for application in many hybrid electric vehicles (HEVs). Hitachi Automotive Systems has produced electric powertrains for several years, and Valeo has recently begun producing electric powertrains.

The leading suppliers may change in the near future with other companies being recognized as the leading performers of R\&D in battery and hybrid electric systems in the United States. A123 and Enerdel perform battery R\&D; and Delphi, Remy, General Motors (GM), Ford, and General Electric (GE) perform hybrid electric system R\&D. DOE has supported A123, Enerdel, Delphi, GM, Ford, and GE. Worldwide, Johnson Controls can be expected to maintain the top rank. Other recognized leaders in battery R\&D abroad include Sanyo, NEC, and LG Chemical. Hitachi, Denso, Toyota, and Aisin are recognized as leaders in R\&D for hybrid electric systems.

Figure 9. Share of Batteries Supplied by Company, 2009

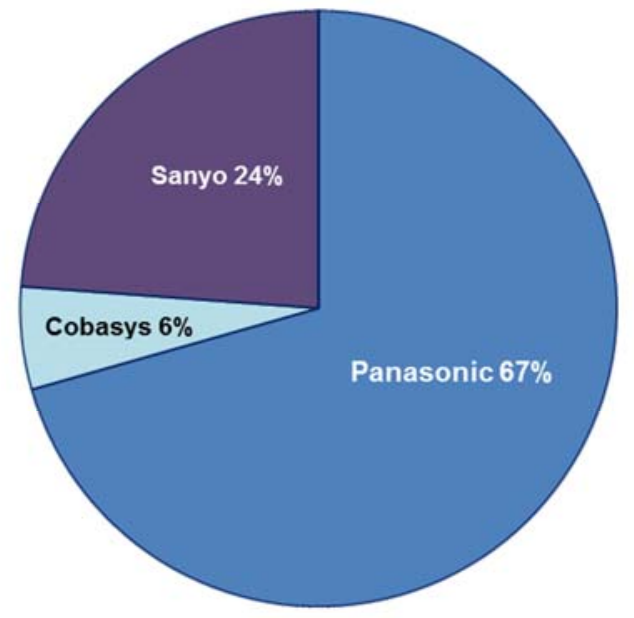

Source: Estimated from HEV sales

Table 3. Batteries Supplied by Manufacturer

\begin{tabular}{|c|c|c|c|c|c|c|}
\hline $\begin{array}{c}\text { Calendar } \\
\text { Year }\end{array}$ & 2005 & 2006 & 2007 & 2008 & 2009 & $\begin{array}{l}\text { Battery } \\
\text { Supplier }\end{array}$ \\
\hline Chrysler & 0 & 0 & 0 & 46 & 42 & Panasonic \\
\hline GMC & 0 & 0 & 5,175 & 11,454 & 16,134 & $\begin{array}{l}\text { Cobasys, } \\
\text { Panasonic }\end{array}$ \\
\hline Ford & 19,795 & 23,323 & 25,108 & 19,502 & 33,502 & Sanyo \\
\hline Honda & 43,356 & 37,571 & 35,980 & 31,493 & 35,691 & Sanyo \\
\hline Nissan & 0 & 0 & 8,388 & 8,819 & 9,357 & Panasonic \\
\hline Toyota & 146,560 & 191,742 & 277,623 & 241,072 & 195,545 & Panasonic \\
\hline Total & 209,711 & 252,636 & 352,274 & 312,386 & 290,271 & \\
\hline
\end{tabular}


Table 4. Batteries Supplied by HEV Model

\begin{tabular}{|c|c|c|c|c|c|c|}
\hline Calendar Year & 2005 & 2006 & 2007 & 2008 & 2009 & $\begin{array}{l}\text { Battery } \\
\text { Supplier }\end{array}$ \\
\hline Cadillac Escalade & 0 & 0 & 0 & 801 & 1,958 & Panasonic \\
\hline Chevy Malibu & 0 & 0 & 0 & 2,093 & 4,162 & Cobasys \\
\hline Chevy Tahoe & 0 & 0 & 0 & 3,745 & 3,300 & Panasonic \\
\hline Chrysler Aspen & 0 & 0 & 0 & 46 & 33 & Panasonic \\
\hline Dodge Durango & 0 & 0 & 0 & 0 & 9 & Panasonic \\
\hline Ford Escape & 18,797 & 20,149 & 21,386 & 17,173 & 14,787 & Sanyo \\
\hline Ford Fusion & 0 & 0 & 0 & 0 & 15,554 & Sanyo \\
\hline GMC Yukon & 0 & 0 & 0 & 1,610 & 1,933 & Panasonic \\
\hline Honda Accord & 16,826 & 5,598 & 3,405 & 196 & 0 & Sanyo \\
\hline Honda Civic & 25,864 & 31,251 & 32,575 & 31,297 & 15,119 & Sanyo \\
\hline Honda Insight & 666 & 722 & 0 & 0 & 20,572 & Sanyo \\
\hline Lexus GS 450h & 0 & 1,784 & 1,645 & 678 & 469 & Panasonic \\
\hline Lexus HS 250h & 0 & 0 & 0 & 0 & 6,699 & Panasonic \\
\hline Lexus LS600hL & 0 & 0 & 937 & 907 & 258 & Panasonic \\
\hline Lexus RX400h & 20,674 & 20,161 & 17,291 & 15,200 & 14,464 & Panasonic \\
\hline Mercury Mariner & 998 & 3,174 & 3,722 & 2,329 & 1,693 & Sanyo \\
\hline Mercury Milan & 0 & 0 & 0 & 0 & 1,468 & Sanyo \\
\hline Nissan Altima & 0 & 0 & 8,388 & 8,819 & 9,357 & Panasonic \\
\hline Saturn Aura & 0 & 0 & 772 & 285 & 527 & Cobasys \\
\hline Saturn Vue & 0 & 0 & 4,403 & 2,920 & 2,656 & Cobasys \\
\hline Sierra/Silverado & 0 & 0 & 0 & 0 & 1,598 & Panasonic \\
\hline Toyota Camry & 0 & 31,341 & 54,477 & 46,272 & 22,887 & Panasonic \\
\hline Toyota Highlander & 17,989 & 31,485 & 22,052 & 19,441 & 11,086 & Panasonic \\
\hline Toyota Prius & 107,897 & 106,971 & 181,221 & 158,574 & 139,682 & Panasonic \\
\hline Total & 209,711 & 252,636 & 352,274 & 312,386 & 290,271 & \\
\hline
\end{tabular}

Source: Estimated from HEV sales

Table 5. Battery and Electric Powertrain Suppliers

\begin{tabular}{|c|c|c|c|c|c|}
\hline \multicolumn{3}{|c|}{2005} & \multicolumn{3}{|c|}{2009} \\
\hline Company & $\begin{array}{c}\text { Total U.S. } \\
\text { Sales (Mil\$) }\end{array}$ & $\begin{array}{c}\text { U.S. \% of } \\
\text { Global } \\
\text { Sales }\end{array}$ & Company & $\begin{array}{c}\text { Total U.S. } \\
\text { Sales (Mil\$) }\end{array}$ & $\begin{array}{c}\text { U.S. \% of Global } \\
\text { Sales }\end{array}$ \\
\hline Johnson Controls Inc. & $8,924.0$ & $(46 \%)$ & Johnson Controls Inc. & $4,992.0$ & $(39 \%)$ \\
\hline Panasonic Automotive Systems & 938.1 & $(30 \%)$ & Panasonic Automotive Systems & 638.8 & $(25 \%)$ \\
\hline \multicolumn{6}{|c|}{ Leading Suppliers in Electric Powertrains } \\
\hline \multicolumn{3}{|c|}{2005} & \multicolumn{3}{|c|}{2009} \\
\hline Company & $\begin{array}{c}\text { Total U.S. } \\
\text { Sales (Mil\$) }\end{array}$ & $\begin{array}{c}\text { U.S. \% of } \\
\text { Global } \\
\text { Sales }\end{array}$ & Company & $\begin{array}{c}\text { Total U.S. } \\
\text { Sales (Mil\$) }\end{array}$ & $\begin{array}{c}\text { U.S. \% of Global } \\
\text { Sales }\end{array}$ \\
\hline \multirow[t]{2}{*}{ Hitachi Automotive Systems Ltd } & $1,484.2$ & $(29 \%)$ & Hitachi Automotive Systems Ltd & $1,312.8$ & $(20 \%)$ \\
\hline & & & Valeo SA & $1,040.0$ & $(10 \%)$ \\
\hline
\end{tabular}




\section{GM and Chrysler undergo major restructuring}

GM and Chrysler both filed for bankruptcy in 2009. At the direction of the Obama Administration, the Federal government intervened to facilitate a restructuring of the two companies. GM cancelled or spun-off the Pontiac, Hummer, Saturn, and Saab brands. Chrysler emerged from bankruptcy under the management control of Fiat (Fabbrica Italiana Automobili Torino) SpA.

Only two years before the bankruptcy, in May 2007, DaimlerChrysler agreed to a deal with Cerberus Capital Management to undo Daimler's merger with Chrysler, ending a 10-year partnership. Thus, data in the table labeled CHR is for DaimlerChrysler through 2007 and for Chrysler alone in 2008/2009. The recent complicated business history for Chrysler means that isolating Chrysler data is difficult. In this report, sales data are only for Chrysler and other business data, such as stock price, are omitted entirely since no continuous time-series is available.

\section{OEM production facilities are concentrated by manufacturer and by state}

All three domestic manufacturers are physically concentrated in Michigan, where they have more production facilities than anywhere else (Table 6). Toyota (TOY), Honda (HON), and Nissan (NIS) have five or fewer facilities each, which are spread across the United States. Though a few plants have opened in the past five years, many more have closed in 2008-2009 due to the decline in sales volumes. Those plants that have opened include Toyota's Tundra plant in San Antonio, Texas, 2006;

Table 6. Light-Vehicle Production Facilities by State and Manufacturer, 2009

\begin{tabular}{|c|c|c|c|c|c|c|c|}
\hline State & GMC & CHR & FMC & TOY & HON & NIS & $\begin{array}{l}\text { State } \\
\text { Totals } \\
\text { for } \\
\text { Selected } \\
\text { OEMs }\end{array}$ \\
\hline AL & & & & & 1 & & 1 \\
\hline CA & 1 & & & 1 & & & $1^{*}$ \\
\hline DE & 1 & & & & & & 1 \\
\hline IL & & 1 & 1 & & & & 2 \\
\hline IN & 1 & & & 2 & 1 & & 4 \\
\hline KS & 1 & & & & & & 1 \\
\hline KY & 1 & & 1 & 1 & & & 3 \\
\hline LA & 1 & & & & & & 1 \\
\hline MI & 6 & 3 & 3 & & & & 12 \\
\hline MN & & & 1 & & & & 1 \\
\hline MO & 1 & 1 & 2 & & & & 4 \\
\hline MS & & & & & & 1 & 1 \\
\hline $\mathrm{OH}$ & 2 & 2 & & & 2 & & 6 \\
\hline TN & 1 & & & & & 1 & 2 \\
\hline TX & 1 & & & 1 & & & 2 \\
\hline $\begin{array}{c}\text { OEM } \\
\text { Total }\end{array}$ & 17 & 7 & 8 & 5 & 4 & 2 & 43 \\
\hline
\end{tabular}

* The joint venture of GM and Toyota (New United Motor Manufacturing, Inc) is listed for each manufacturer, but is only counted once in the total.

Notes: State total includes only those manufacturers shown on this table. The Subaru plant that produces Toyota Camrys is not included under Toyota.

Source: Ward's Autolnfobank 
General Motors, Lansing, Michigan, 2006; and Honda, Greensburg, Indiana, 2008. Between 2008 and 2009, the domestic manufacturers closed a total of ten plants, with General Motors accounting for half of that ten.

\section{Sales volumes have decreased significantly and market shares have shifted among top OEMs}

Due to economic difficulties in the United States, sales of cars and light trucks in 2009 were even lower than the 2008 sales. During a five-year period (2005 to 2009), sales of light trucks declined by more than $46 \%$, while sales of cars declined nearly $30 \%$. According to Ward's

AutoInfoBank data, light-truck sales had declined slightly each year from 2005 to 2007, but the 2.1 million drop in vehicle sales from 2007 to 2008 was sudden and followed by another 1.4 million drop from 2008 to 2009 . Car sales declined by 0.8 million from 2007 to 2008 and 1.35 million from 2008 to 2009 (Table 7).
In 2005, domestic manufacturers-General Motors (GMC), Ford (FMC), and DaimlerChrysler (DCC/CHR) comprised $43 \%$ of car sales and $70 \%$ of light-truck sales. By 2009, the domestic share of car sales dropped sharply to $32 \%$ and light truck sales to about 59\%. The change in car sales is even more dramatic when considered by company: in 2009, General Motors sold half of what they did in 2005 and Chrysler sold less than half the number of cars they sold in 2005. Both companies light truck sales were also down by more than half of what they sold in 2005.

The domestically owned automakers represented a 58\% share of all light-vehicle sales in 2005 (Figure 10). By 2009, the domestic automaker's share of light-vehicle sales dropped to less than half (45\%). Conversely, the foreign-owned manufacturers all gained market share during the same period. Toyota led the imports with $17 \%$ of all light-vehicle sales in 2009.

Table 7. New Vehicle Sales and Market Shares by Manufacturer

\begin{tabular}{|c|c|c|c|c|c|c|}
\hline \multicolumn{7}{|c|}{ Car Sales Volumes (Millions of Vehicles) } \\
\hline Calendar Year & $\mathbf{2 0 0 5}$ & $\mathbf{2 0 0 6}$ & $\mathbf{2 0 0 7}$ & $\mathbf{2 0 0 8}$ & $\mathbf{2 0 0 9}$ & $\mathbf{5}-\mathbf{y r} \boldsymbol{\Delta}$ \\
\hline GMC & 1.74 & 1.62 & 1.49 & 1.26 & 0.87 & $-49.8 \%$ \\
\hline FMC & 1.01 & 1.07 & 0.82 & 0.72 & 0.63 & $-37.5 \%$ \\
\hline CHR & 0.58 & 0.55 & 0.57 & 0.41 & 0.23 & $-60.6 \%$ \\
\hline TOY & 1.29 & 1.46 & 1.51 & 1.36 & 1.05 & $-18.2 \%$ \\
\hline HON & 0.84 & 0.84 & 0.88 & 0.88 & 0.70 & $-16.6 \%$ \\
\hline NIS & 0.57 & 0.55 & 0.64 & 0.59 & 0.51 & $-9.8 \%$ \\
\hline OTHER & 1.69 & 1.73 & 1.71 & 1.59 & 1.45 & $-14.0 \%$ \\
\hline ALL & 7.72 & 7.82 & 7.62 & 6.81 & 5.46 & $-29.3 \%$ \\
\hline
\end{tabular}

\begin{tabular}{|c|c|}
\hline \multicolumn{2}{|c|}{ Car Market Share } \\
\hline 2005 & $\mathbf{2 0 0 9}$ \\
\hline $22.5 \%$ & $16.0 \%$ \\
\hline $13.1 \%$ & $11.6 \%$ \\
\hline $7.5 \%$ & $4.2 \%$ \\
\hline $16.7 \%$ & $19.3 \%$ \\
\hline $10.9 \%$ & $12.8 \%$ \\
\hline $7.4 \%$ & $9.4 \%$ \\
\hline $21.9 \%$ & $26.6 \%$ \\
\hline $100.0 \%$ & $100.0 \%$ \\
\hline
\end{tabular}

\begin{tabular}{|c|c|c|c|c|c|c|}
\hline \multicolumn{7}{|c|}{ Light Truck Sales Volumes (Millions of Vehicles) } \\
\hline Calendar Year & $\mathbf{2 0 0 5}$ & $\mathbf{2 0 0 6}$ & $\mathbf{2 0 0 7}$ & $\mathbf{2 0 0 8}$ & $\mathbf{2 0 0 9}$ & $\mathbf{5}$-yr $\mathbf{~}$ \\
\hline GMC & 2.71 & 2.45 & 2.34 & 1.70 & 1.20 & $-55.8 \%$ \\
\hline FMC & 2.02 & 1.71 & 1.62 & 1.23 & 1.02 & $-49.3 \%$ \\
\hline CHR & 1.73 & 1.59 & 1.51 & 1.04 & 0.70 & $-59.6 \%$ \\
\hline TOY & 0.97 & 1.08 & 1.11 & 0.86 & 0.72 & $-26.2 \%$ \\
\hline HON & 0.62 & 0.67 & 0.67 & 0.55 & 0.45 & $-27.3 \%$ \\
\hline NIS & 0.50 & 0.47 & 0.43 & 0.36 & 0.26 & $-48.8 \%$ \\
\hline OTHER & 0.68 & 0.71 & 0.79 & 0.64 & 0.60 & $-11.4 \%$ \\
\hline ALL & 9.23 & 8.68 & 8.47 & 6.38 & 4.95 & $-46.4 \%$ \\
\hline
\end{tabular}

\begin{tabular}{|c|c|}
\hline \multicolumn{2}{|c|}{ LT Market Share } \\
\hline $\mathbf{2 0 0 5}$ & $\mathbf{2 0 0 9}$ \\
\hline $29.4 \%$ & $24.2 \%$ \\
\hline $21.9 \%$ & $20.7 \%$ \\
\hline $18.7 \%$ & $14.1 \%$ \\
\hline $10.5 \%$ & $14.5 \%$ \\
\hline $6.7 \%$ & $9.1 \%$ \\
\hline $5.4 \%$ & $5.2 \%$ \\
\hline $7.4 \%$ & $12.2 \%$ \\
\hline $100.0 \%$ & $100.0 \%$ \\
\hline
\end{tabular}

Source: Ward's AutolnfoBank 
Figure 10. New Vehicle Shares by Manufacturer
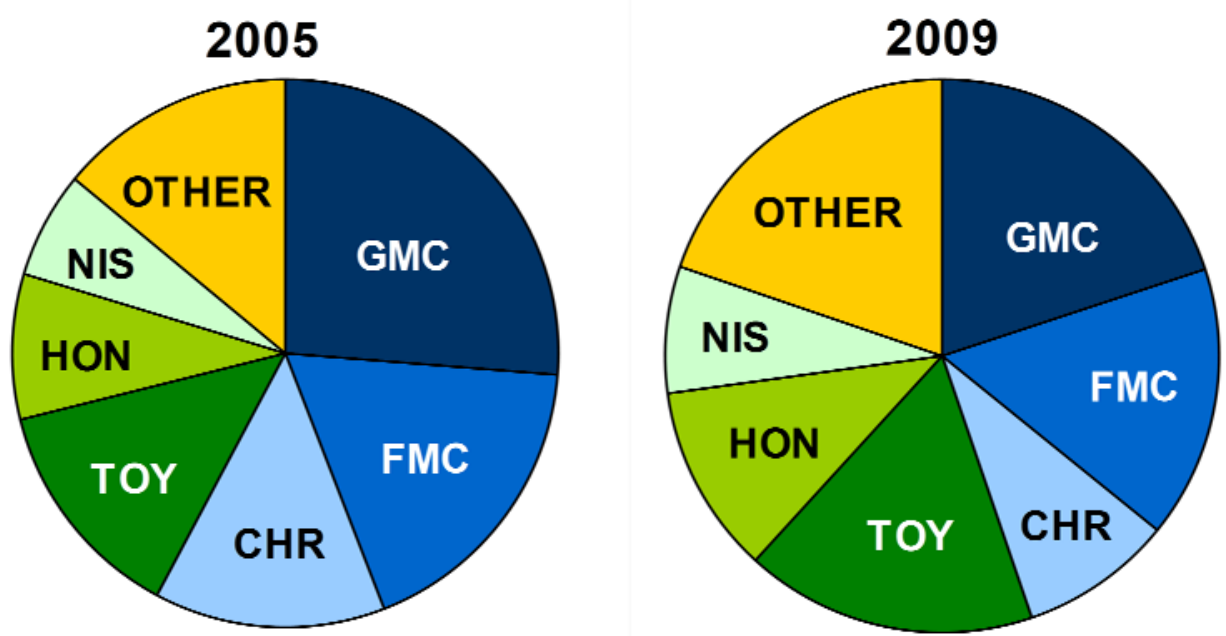

Source: Ward's AutolnfoBank

\section{Federal scrappage program created demand for new cars}

The Car Allowance Rebate System, also known as the Cash for Clunkers Program, provided Federal rebate money for consumers who traded old vehicles with an EPA combined fuel economy rating of 18 miles per gallon or less for brand new vehicles with improved fuel economy. The program was active from July 1 to August 24, 2009 and about 677,000 vehicles were traded. The average fuel economy for traded vehicles was 15.8 miles per gallon (mpg), while the average for the newly purchased vehicles was $24.9 \mathrm{mpg}$ - a 58\% improvement. The majority of vehicles traded were trucks (85\%), but the vehicles purchased were mostly passenger cars (59\%). The fourwheel drive Ford Explorer was the top trade-in vehicle, while the Toyota Camry was the top vehicle purchased (Table 8). In addition to creating a demand for new light vehicles, the program also made an impact by raising the average fuel economy of the fleet. Cars purchased under the program are, on average, $19 \%$ above the average fuel economy of all new cars.

\section{Major manufacturers have been hard hit by the general economic recession}

While the general economic recession was clearly visible in late 2008 , it could be seen in the auto industry about 12 months earlier. The stock prices of the five of the large auto manufacturers peaked in late 2007 (Figure 11). Chrysler historical stock prices are not shown due to company changes from Daimler-Chrysler to Chrysler to Fiat-Chrysler during this five year period. General Motors stock prices are from the company before bankruptcy in mid-2009. Though Figure 11 shows stock prices declining in 2008, the prices increase in 2009 to a level similar to that of 2005, with the exception of General Motors.

\section{Real average vehicle costs are decreasing slightly}

Average vehicle costs have slowly declined over the past five years to $\$ 23,186$ in 2009 (Table 9). The last time vehicle costs were near $\$ 23,000$ was in the mid-1980’s (Figure 12). Real average vehicle cost has been near $\$ 25,000$ since 1986 . In addition, recent stability in regulatory policy - the CAFE Standards did not change significantly until 2008-has caused few perturbations to OEM planning, which has facilitated cost-effective technological improvements and a gradual decrease in prices from a peak of just above \$25,000 in 1998 . 
Table 8. Top 10 Vehicles in the Car Allowance Rebate System

\section{Top 10 Trade-in Vehicles}

Ford Explorer 4WD

Ford F150 Pickup 2WD

Jeep Grand Cherokee 4WD

Ford Explorer 2WD

Dodge Caravan/Grand Caravan 2WD

Jeep Cherokee 4WD

Chevrolet Blazer 4WD

Ford F150 Pickup 4WD

Chevrolet C1500 Pickup 2WD

Ford Windstar FWD Van

\section{Top 10 New Vehicles Purchased}

Toyota Corolla

Honda Civic

Toyota Camry

Ford Focus FWD

Hyundai Elantra

Nissan Versa

Toyota Prius

Honda Accord

Honda Fit

Ford Escape FWD

Note: $2 W D=$ two-wheel drive; $4 W D=$ four-wheel drive; FWD = frontwheel drive.

Source: NHTSA

Figure 11. Stock Prices for Major Vehicle Manufacturers

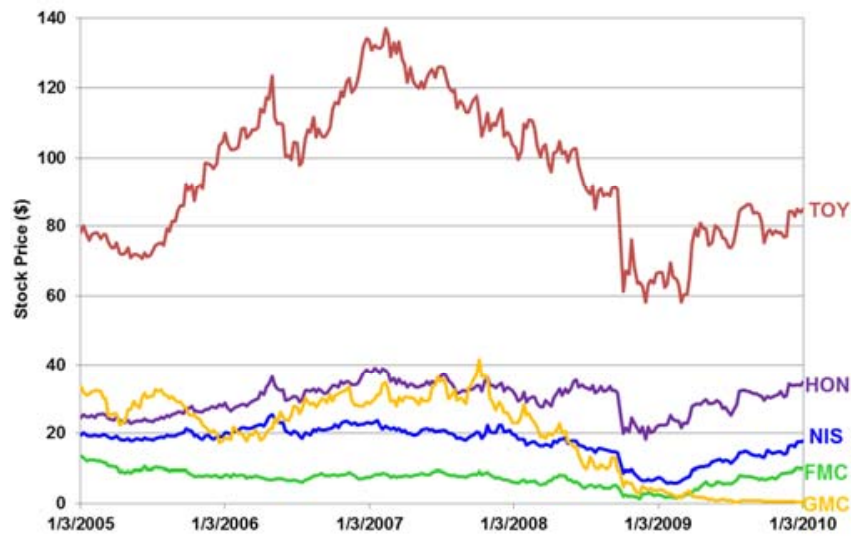

Source: Yahoo Finance
Table 9. Average Vehicle Cost

\begin{tabular}{|c|c|}
\hline $\begin{array}{c}\text { Calendar } \\
\text { Year }\end{array}$ & $\begin{array}{c}\text { Real Price } \\
\text { (\$2009) }\end{array}$ \\
\hline $\mathbf{2 0 0 5}$ & 25,284 \\
\hline $\mathbf{2 0 0 6}$ & 25,151 \\
\hline $\mathbf{2 0 0 7}$ & 24,721 \\
\hline $\mathbf{2 0 0 8}$ & 23,334 \\
\hline $\mathbf{2 0 0 9}$ & 23,186 \\
\hline $\mathbf{5}$-yr $\boldsymbol{\Delta}$ & $-8.3 \%$ \\
\hline
\end{tabular}

Source: Bureau of Economic Analysis, National Income and Product Accounts

Figure 12. Average Price of a New Car

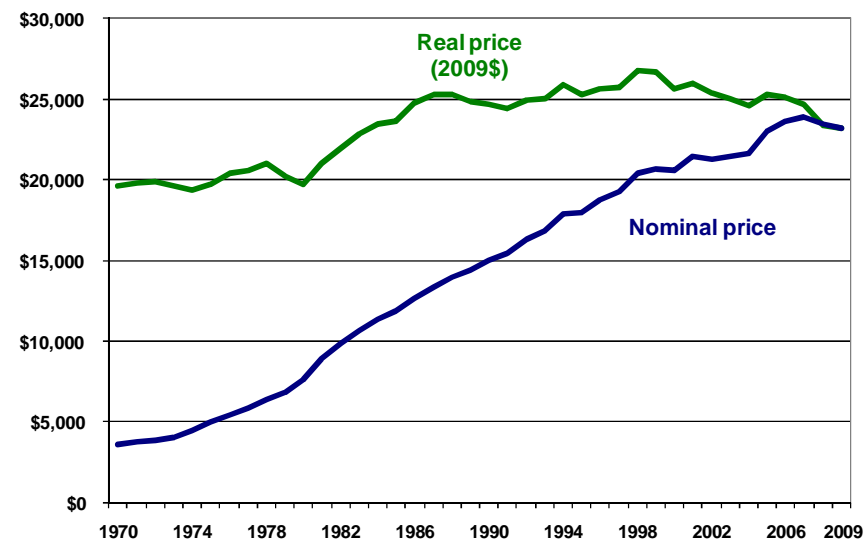

Source: Bureau of Economic Analysis, National Income and Product Accounts 


\section{Light trucks make up $\mathbf{4 7 . 5}$ percent of new vehicle sales}

The light-truck share of new vehicle sales during the past five years reached a peak in 2004-2005 (Table 10 and Figure 13). Until that point, light-truck sales' share had increased steadily, from around $20 \%$ in the 1980 s to just above $50 \%$ in more recent years. Light-truck sales declined relative to car sales in 2006 as a result of (1) increasing oil prices, which discouraged buying vehicles with poor fuel economy, and (2) the introduction of the crossover - a vehicle derived from a car platform but borrowing features from a sport utility vehicle (SUV). Depending on their characteristics, some crossovers are classified as cars. Thus, consumers still interested in SUV-like vehicles are buying a vehicle actually classified as a car. It appears that the shift in purchasing patterns is not simply a slowing of what seemed to be an ever-increasing increase of light-truck sales share, but a marked reversal in purchasing behavior. The decrease in light-truck sales' shares between 2005 and 2009 signifies that consumers shifted toward cars.

Table 10. Light Truck Share of Total Light Vehicle

\begin{tabular}{|c|c|c|c|c|c|c|}
\hline $\begin{array}{c}\text { Calendar } \\
\text { Year }\end{array}$ & 2005 & 2006 & 2007 & 2008 & 2009 & 5-yr $\Delta$ \\
\hline GMC & $16.0 \%$ & $14.8 \%$ & $14.5 \%$ & $12.9 \%$ & $11.5 \%$ & $-28.0 \%$ \\
\hline FMC & $11.9 \%$ & $10.4 \%$ & $10.1 \%$ & $9.3 \%$ & $9.8 \%$ & $-17.4 \%$ \\
\hline CHR & $10.2 \%$ & $9.6 \%$ & $9.4 \%$ & $7.9 \%$ & $6.7 \%$ & $-34.2 \%$ \\
\hline TOY & $5.7 \%$ & $6.5 \%$ & $6.9 \%$ & $6.5 \%$ & $6.9 \%$ & $20.2 \%$ \\
\hline HON & $3.7 \%$ & $4.1 \%$ & $4.2 \%$ & $4.2 \%$ & $4.3 \%$ & $18.4 \%$ \\
\hline NIS & $2.9 \%$ & $2.8 \%$ & $2.7 \%$ & $2.7 \%$ & $2.5 \%$ & $-16.6 \%$ \\
\hline OTHER & $4.0 \%$ & $4.3 \%$ & $4.9 \%$ & $4.9 \%$ & $5.8 \%$ & $44.4 \%$ \\
\hline ALL & $54.5 \%$ & $52.6 \%$ & $52.6 \%$ & $48.4 \%$ & $47.5 \%$ & $-12.7 \%$ \\
\hline
\end{tabular}

Source: Ward's AutolnfoBank

General Motors, Ford, and Chrysler depend heavily on light truck sales, which are more than half of their total light vehicle sales (Table 11). Light trucks are about $40 \%$ of Toyota and Honda light vehicle sales in 2009, while Nissan's light truck share is 33\%. Though most manufacturers' light truck sales share declined from 2005 to 2009 , there is no clear trend of decline in the intervening years - the shares are both up and down over the five-year period. The only manufacturer to increase their share of light trucks when comparing 2005 to 2009 data is Chrysler. However, because the 2005 data include Daimler and the 2009 data do not, it is not as accurate a comparison as the other manufacturers.
Figure 13. Share of New Vehicle Sales by Vehicle Type

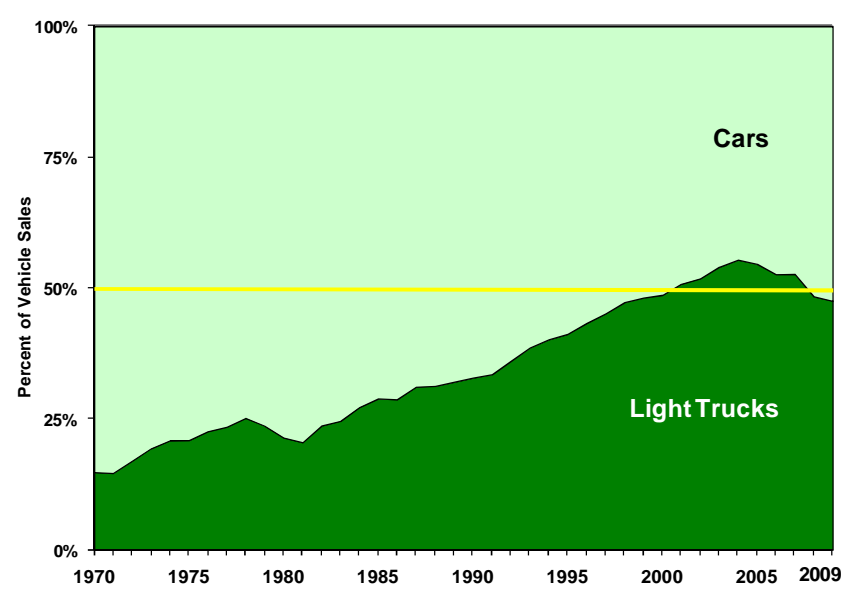

Source: Ward's AutolnfoBank

Table 11. Light Trucks Sales Share by Manufacturer

\begin{tabular}{|l|l|l|l|l|l|r|}
\hline $\begin{array}{c}\text { Calendar } \\
\text { Year }\end{array}$ & $\mathbf{2 0 0 5}$ & $\mathbf{2 0 0 6}$ & $\mathbf{2 0 0 7}$ & $\mathbf{2 0 0 8}$ & $\mathbf{2 0 0 9}$ & $\mathbf{5 - y r} \boldsymbol{\Delta}$ \\
\hline GMC & $60.9 \%$ & $60.2 \%$ & $61.1 \%$ & $57.4 \%$ & $57.8 \%$ & $-5.1 \%$ \\
\hline FMC & $66.7 \%$ & $61.5 \%$ & $66.4 \%$ & $63.1 \%$ & $61.9 \%$ & $-7.2 \%$ \\
\hline CHR & $74.9 \%$ & $74.3 \%$ & $72.6 \%$ & $71.7 \%$ & $75.3 \%$ & $0.6 \%$ \\
\hline TOY & $42.9 \%$ & $42.5 \%$ & $42.4 \%$ & $38.7 \%$ & $40.4 \%$ & $-5.8 \%$ \\
\hline HON & $42.5 \%$ & $44.4 \%$ & $43.2 \%$ & $38.5 \%$ & $39.2 \%$ & $-7.8 \%$ \\
\hline NIS & $46.7 \%$ & $46.1 \%$ & $40.2 \%$ & $37.9 \%$ & $33.2 \%$ & $-28.9 \%$ \\
\hline OTHER & $28.7 \%$ & $29.1 \%$ & $31.6 \%$ & $28.7 \%$ & $29.3 \%$ & $2.2 \%$ \\
\hline ALL & $54.5 \%$ & $52.6 \%$ & $52.6 \%$ & $48.4 \%$ & $47.5 \%$ & $-12.7 \%$ \\
\hline
\end{tabular}

Source: Ward's AutolnfoBank

\section{CAFE has increased for cars and light trucks}

CAFE - the sales-weighted harmonic mean fuel economy of a manufacturer's fleet of current model year cars or light trucks with a gross vehicle weight rating (GVWR) of 8,500 pounds or less-has increased slightly during the past five years. The requirement for cars has been held constant at 27.5 miles per gallon (mpg) during this period, while the requirement for light trucks has increased from $21.0 \mathrm{mpg}$ in model year (MY) 2005 to 23.1 in MY 2009 (an increase of 10\%). The actual fuel economy improvement for cars during the past five years was 2.3 mpg (an increase of 7.6\%), while the actual fuel economy increase for light trucks was $2.5 \mathrm{mpg}$ (an increase of 11.3\%) (Figure 14). 
Figure 14. CAFE and CAFE Standards by Vehicle Type

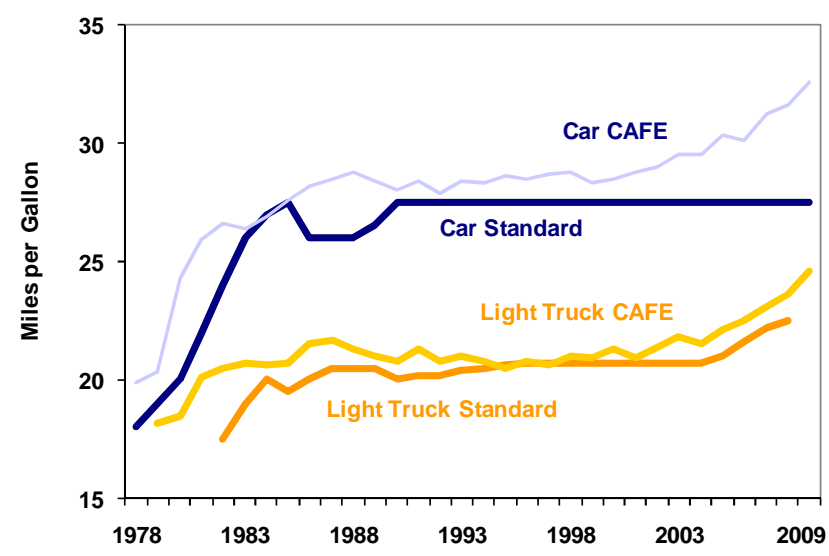

Source: NHTSA, Summary of Fuel Economy Performance

CAFE compliance is measured by vehicle fleet: "domestic passenger cars," "import passenger cars," and "light trucks." There is a statutory two-fleet rule for passenger cars. Manufacturers' domestic and import fleets must separately meet the $27.5 \mathrm{mpg}$ CAFE standard. For passenger cars, a vehicle (irrespective of who makes it) is considered part of the "domestic fleet" if 75\% or more of the cost of the content originates in the United States, Canada, or Mexico. If not, it is considered an import. Light trucks were administratively subjected to a similar twofleet rule in the past, but the National Highway Traffic Safety Administration (NHTSA) eliminated the two-fleet rule for light trucks beginning with MY 1996. Therefore, there are no fleet distinctions, and trucks are simply counted and CAFE calculated as one distinct fleet of a given manufacturer.

According to the 2009 CAFE data among the top 6 OEMs, Honda sold the most fuel-efficient fleet of domestic passenger cars, while Toyota sold the most fuel- efficient fleet of import passenger cars and the most fuel-efficient fleet of light trucks (Table 12). Chrysler manufactured the least fuel-efficient domestic car fleet, Ford manufactured the least efficient import passenger cars, and General Motors manufactured the least fuel-efficient light truck fleet. Honda and Nissan achieved significant improvements in domestic passenger car fuel economy in the past five years. Nissan achieved a large gain in import passenger car fuel economy. Ford's and General Motors' import passenger cars and Chrysler's domestic passenger cars CAFE figures actually declined from 2005 to 2009. CAFE figures are a function not only of the vehicles manufactured, but also of the sales mix: Manufacturers that sell a greater number of more fuel-efficient vehicles will have higher CAFE numbers.
Table 12. CAFE by Manufacturer Corporate Average Fuel Economy (miles per gallon) Domestic Passenger Cars

\begin{tabular}{|c|c|c|c|c|c|c|}
\hline & 2005 & 2006 & 2007 & 2008 & 2009 & $5-\mathrm{yr} \Delta$ \\
\hline CHR & 28.8 & 26.0 & 28.5 & 29.3 & 28.5 & $-1.04 \%$ \\
\hline FMC & 28.6 & 28.2 & 29.0 & 30.1 & 31.1 & $8.74 \%$ \\
\hline GMC & 29.3 & 29.9 & 30.0 & 29.6 & 31.0 & $5.80 \%$ \\
\hline HON & 33.2 & 33.8 & 33.5 & 36.0 & 36.5 & $9.94 \%$ \\
\hline NIS & 30.7 & 31.1 & 33.4 & 33.9 & 33.6 & $9.45 \%$ \\
\hline TOY & 34.4 & 34.6 & 31.3 & 34.0 & 35.8 & $4.07 \%$ \\
\hline \multicolumn{7}{|c|}{ Import Passenger Cars } \\
\hline & 2005 & 2006 & 2007 & 2008 & 2009 & 5-yr $\Delta$ \\
\hline CHR & 25.9 & 24.7 & 24.7 & 26.5 & * & * \\
\hline FMC & 27.7 & 28.4 & 29.8 & 31.1 & 26.8 & $-3.25 \%$ \\
\hline GMC & 30.5 & 29.0 & 32.3 & 31.5 & 30.2 & $-0.98 \%$ \\
\hline HON & 33.1 & 34.5 & 39.3 & 33.5 & 34.0 & $2.72 \%$ \\
\hline NIS & 24.8 & 24.3 & 29.6 & 29.2 & 32.2 & $29.84 \%$ \\
\hline TOY & 36.6 & 35.0 & 38.3 & 38.3 & 39.2 & $7.10 \%$ \\
\hline \multicolumn{7}{|c|}{ Light Trucks } \\
\hline & 2005 & 2006 & 2007 & 2008 & 2009 & 5-yr $\Delta$ \\
\hline CHR & 21.4 & 21.7 & 22.9 & 23.6 & 24.1 & $12.62 \%$ \\
\hline FMC & 21.6 & 21.1 & 22.3 & 23.6 & 24.4 & $11.11 \%$ \\
\hline GMC & 21.8 & 22.8 & 22.4 & 23.2 & 23.5 & $8.72 \%$ \\
\hline HON & 24.9 & 24.7 & 25.1 & 25.5 & 26.0 & $7.23 \%$ \\
\hline NIS & 21.7 & 21.9 & 22.9 & 23.1 & 24.9 & $16.13 \%$ \\
\hline TOY & 23.1 & 23.7 & 23.7 & 23.9 & 26.1 & $15.58 \%$ \\
\hline
\end{tabular}

* Note that Chrysler sold no import passenger cars in 2009.

Source: NHTSA, Summary of Fuel Economy Performance

Because greenhouse gas emissions are tied to the amount of fuel burned, the fuel economy of vehicles affects the amount of $\mathrm{CO}_{2}$ released into the atmosphere. EPA calculates vehicles' carbon footprint using average car and light-truck fuel economy and assuming 15,000 miles per year. Figure 15 shows that the average carbon footprint for cars and light trucks has not changed a lot during the past 20 years. Despite this apparent stagnation, engines and other performance metrics have improved, as later figures and discussion will show. Consumers have opted for bigger, more powerful vehicles, and their choosing power over fuel economy has effectively nullified any historical potential for fuel efficiency gains. Table 13 shows the average carbon footprint for a Ford Taurus over time. The recent change to a 6 -speed, 3.5 liter engine reduced the amount of $\mathrm{CO}_{2}$ that the average Taurus will emit, despite the increase in size (passenger volume). 
Figure 15. Average Annual Carbon Footprint for New Vehicles Sold by Model Year

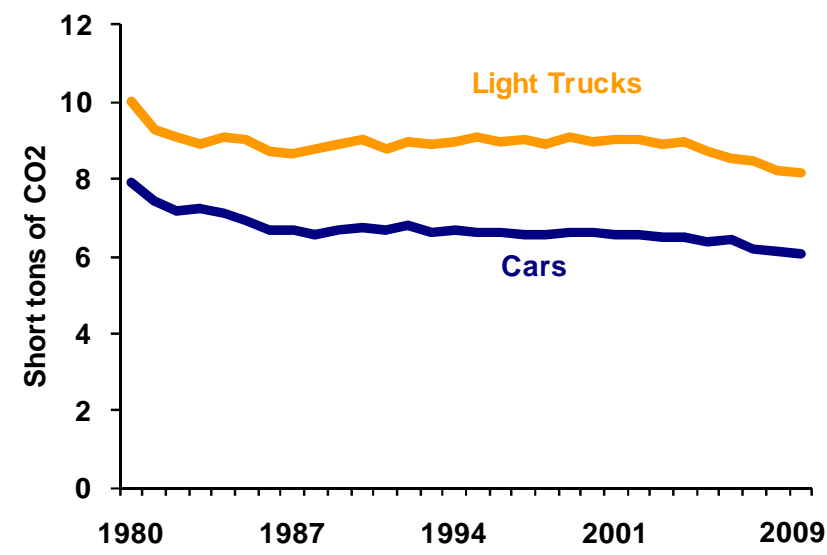

Source: EPA, Light-Duty Automotive Technology and Fuel Economy Trends: 1975-2008, and Fueleconomy.Gov

Table 13. Carbon Footprint for a Ford Taurus

\begin{tabular}{|c|c|c|c|}
$\begin{array}{c}\text { Model } \\
\text { Year }\end{array}$ & $\begin{array}{c}\text { Annual } \\
\text { Tons of } \\
\text { CO2 per } \\
\text { year }\end{array}$ & \multicolumn{1}{|c|}{ Engine Description } & $\begin{array}{c}\text { Passenger } \\
\text { Volume } \\
\text { (Cubic Feet) }\end{array}$ \\
\hline $\mathbf{1 9 8 6}$ & 9.3 & Automatic, 4-spd, 6 cyl, 3.0 L & 100.00 \\
\hline $\mathbf{1 9 9 6}$ & 9.3 & Automatic, 4-spd, 6 cyl, 3.0 L & 102.00 \\
\hline $\mathbf{2 0 0 6}$ & 9.3 & Automatic, 4-spd, 6 cyl, 3.0 L & 105.00 \\
\hline $\mathbf{2 0 1 0}$ & 8.5 & Automatic, 6-spd, 6 cyl, 3.5 L & 108.00 \\
\hline
\end{tabular}

Source: DOE/EPA, Fueleconomy.Gov

When looking at the average carbon footprint per vehicle on a manufacturer level, as shown in Figure 16, four of the six manufacturers had a smaller average footprint in 2009 than they did in 1980. Honda and Nissan, the two for which the average per-vehicle carbon footprint was greater in 2009, have added large trucks and vans to their vehicle line-up since 1980 . The coincidence of most OEM's carbon footprint peak in 2004-2005 and the peak in the percentage of light truck sales can be seen by comparing this table with Figure 13.

Figure 16. Average Carbon Footprint per Vehicle by Manufacturer

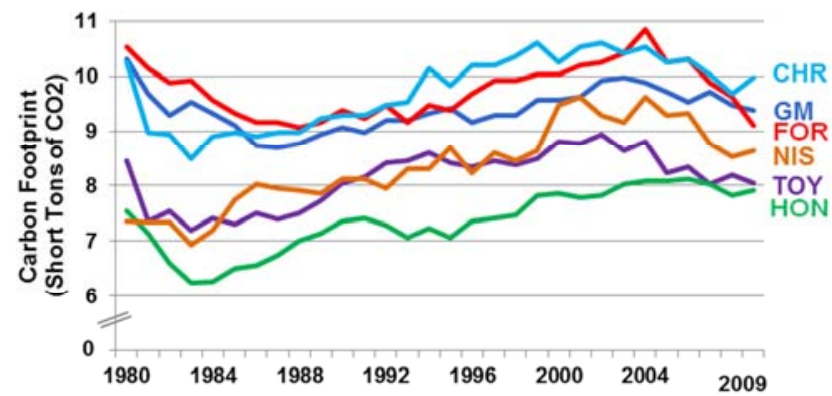

Source: EPA, Light-Duty Automotive Technology, Carbon Dioxide Emissions, and Fuel Economy Trends: 1975 Through 2009

\section{Most light vehicles gained weight}

During the past five years, new cars gained an average of 70 pounds $(2 \%)$ and light trucks gained an average of 44 pounds (1.3\%) (Table 14). General Motors increased the average weight of their vehicles by more than $5 \%$ in that time period. New cars made by Nissan were actually lighter in 2009 than in 2005. (Because this is a salesweighted average, it may not mean that the individual vehicles are lighter, but the average of vehicles sold is lighter.) For light trucks, General Motors and Ford increased the average weight of their vehicles by more than $5 \%$. Ford had a substantial decrease in the weight of light trucks during this period (6.5\%).

Table 14. Average New Vehicle Weight by Manufacturer

\begin{tabular}{|l|r|r|r|r|r|r|}
\hline $\begin{array}{c}\text { Model } \\
\text { Year }\end{array}$ & $\mathbf{2 0 0 5}$ & $\mathbf{2 0 0 6}$ & $\mathbf{2 0 0 7}$ & $\mathbf{2 0 0 8}$ & $\mathbf{2 0 0 9}$ & $\mathbf{5}-\mathbf{y r} \boldsymbol{\Delta}$ \\
\hline GMC & 3,462 & 3,562 & 3,566 & 3,640 & 3,649 & $5.4 \%$ \\
\hline FOR & 3,648 & 3,682 & 3,584 & 3,686 & 3,654 & $0.2 \%$ \\
\hline CHR & 3,756 & 3,949 & 3,822 & 3,786 & 3,873 & $3.1 \%$ \\
\hline TOY & 3,223 & 3,236 & 3,362 & 3,322 & 3,331 & $3.4 \%$ \\
\hline HON & 3,308 & 3,335 & 3,289 & 3,333 & 3,356 & $1.5 \%$ \\
\hline NIS & 3,521 & 3,525 & 3,483 & 3,463 & 3,410 & $-3.2 \%$ \\
\hline ALL & 3,463 & 3,534 & 3,507 & 3,527 & 3,533 & $2.0 \%$ \\
\hline & & Light Trucks & & & \\
\hline GMC & 4,926 & 4,795 & 5,222 & 5,090 & 5,102 & $5.1 \%$ \\
\hline FOR & 4,869 & 5,003 & 4,899 & 4,653 & 4,643 & $-6.5 \%$ \\
\hline CHR & 4,561 & 4,645 & 4,592 & 4,618 & 4,720 & $4.6 \%$ \\
\hline TOY & 4,413 & 4,459 & 4,531 & 4,630 & 4,551 & $4.0 \%$ \\
\hline HON & 4,179 & 4,227 & 4,242 & 4,192 & 4,251 & $2.1 \%$ \\
\hline NIS & 4,752 & 4,746 & 4,667 & 4,744 & 4,692 & $-1.7 \%$ \\
\hline ALL & 4,668 & 4,665 & 4,752 & 4,710 & 4,712 & $1.3 \%$ \\
\hline SOUr
\end{tabular}

Source: EPA, Light-Duty Automotive Technology and Fuel Economy Trends: $1975-2009$ 


\section{Consumers are purchasing more powerful engines}

From 1980 to 2009, there have been significant gains made in automotive technology, but those advancements have been applied toward improved performance and safety rather than fuel economy. Horsepower has more than doubled, top speed has climbed from 107 miles per hour to 139 miles per hour, and "0-to-60" times have dropped from 14.3 seconds to 9.5 seconds (Figure 17). Average vehicle weight has increased nearly $30 \%$ during the same period, primarily due to increased vehicle size as well as reinforced structures and added equipment such as airbags that improve crashworthiness. During this same period, fuel economy has remained relatively unchanged, with only a $2.9 \%$ increase in average light-vehicle fuel economy between 1981 and 2009.

Figure 18 shows indices of the horsepower, weight, fuel economy, and 0-60 time by manufacturer from 2005 to 2009. Keeping in mind that each manufacturer is indexed to the fleet average in 2005, the figure shows not only how each manufacturer compares to the average, but also the changes that the manufacturers are making during this turbulent time in the light vehicle market. The changes to Ford's light vehicles over the past five years are noteworthy - fuel economy and horsepower are up, while weight and 0-60 time are down. However, the fuel economy average for Ford's light vehicles in 2005 was below the industry average. The 2006 introduction of the Ford Fusion is likely to have helped raise Ford's average fuel economy. The redesign of the Toyota Tundra in 2007, with a substantial increase in horsepower, is evident in the figure. Honda's light vehicles in 2009 are very similar to that of 2005. However, Honda's average fuel economy is well above the industry average, while weight and horsepower are below the industry average. The Nissan Versa, introduced in 2007, is likely responsible for Nissan's average fuel economy improvement.

\section{Figure 17. Characteristics of New Light Vehicles Sold, MY 1980-2009}

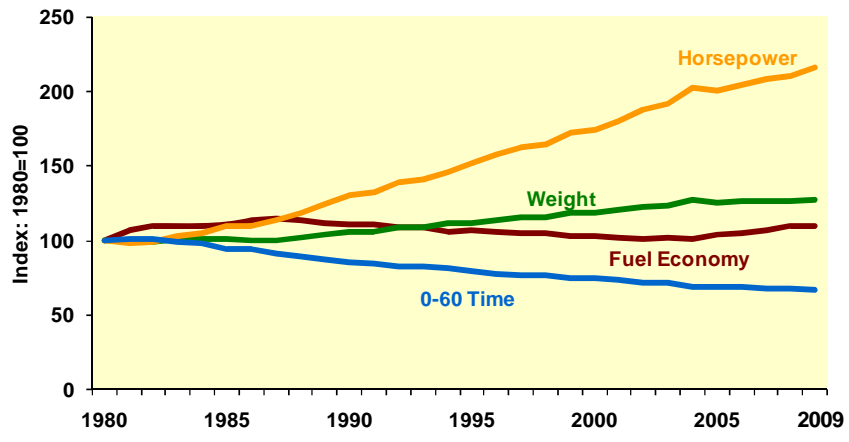

Source: EPA, Light-Duty Automotive Technology and Fuel Economy Trends: $1975-2009$
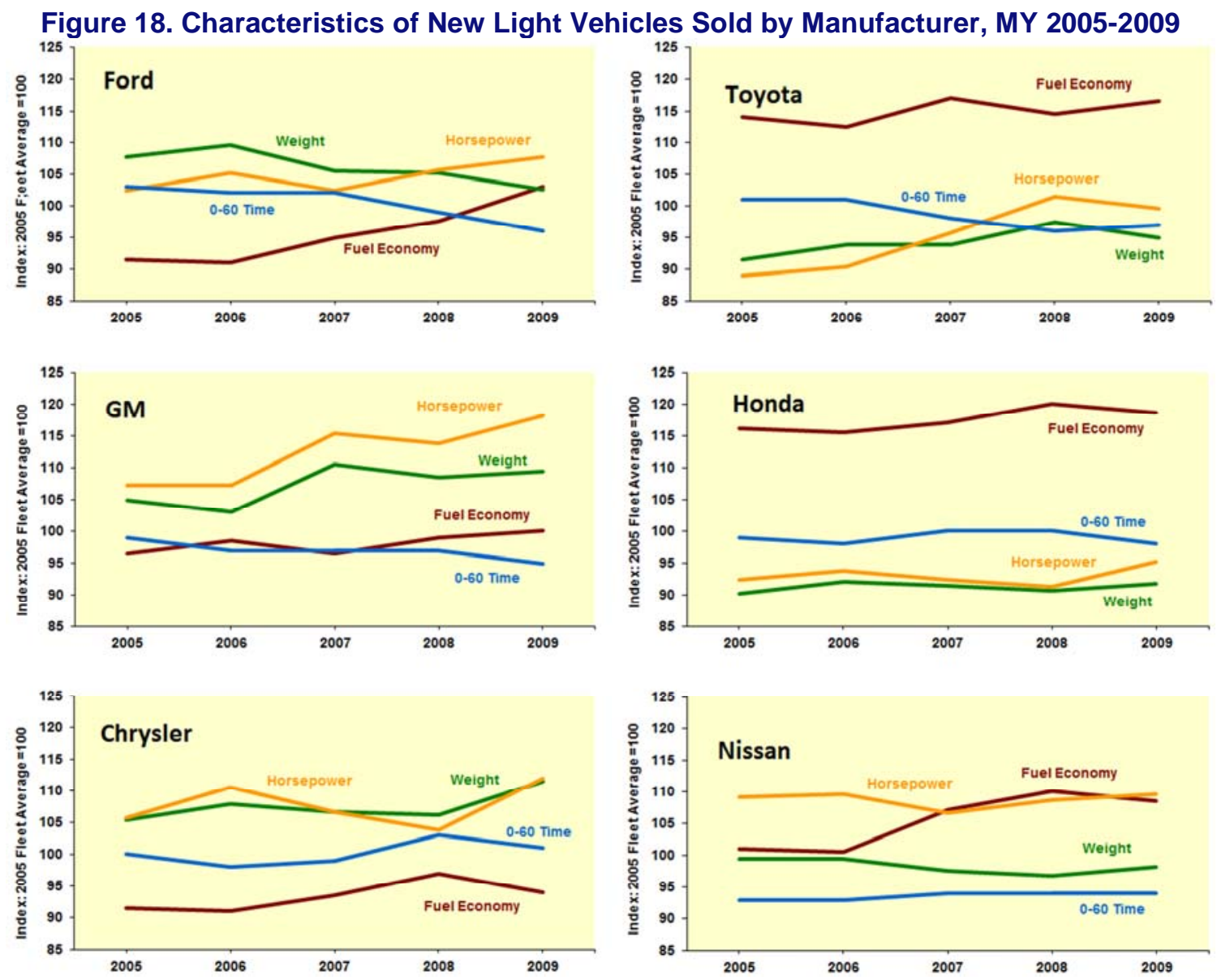
Engine displacement and horsepower are often closely related. Figure 19 shows an obvious spike in horsepower for DaimlerChrysler cars in 2006. This increase in horsepower from 2005 corresponds to the rising popularity of the larger V8 "HEMI" engines made available on many Dodge and Chrysler cars. The price of gasoline began to increase sharply after 2006, depressing demand for the larger engines.

\section{Figure 19. Car and Light Truck Horsepower by Manufacturer}
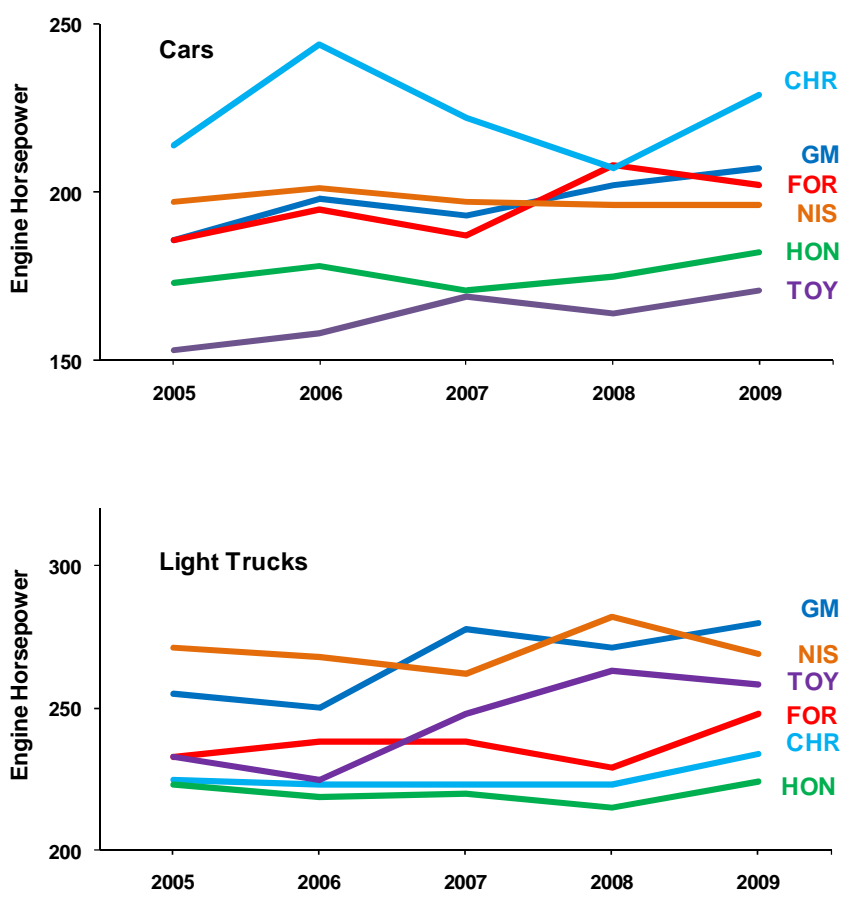

Note: Cars include wagons.

Source: EPA, Light-Duty Automotive Technology and Fuel Economy Trends: $1975-2008$

Although bigger engines typically provide greater horsepower, they also lead to increased weight, which hinders fuel economy and performance. Advancements in engine design and overall engine technology can increase horsepower without increasing engine size. Ford cars experienced an overall decrease in engine displacement of $2.6 \%$, while increasing horsepower $9 \%$ from 2005 to 2009 (Table 15). Honda also managed to increase the horsepower of their cars without increasing engine displacement. Nissan decreased engine displacement in cars, but held horsepower steady. For trucks, Ford and Chrysler reduced their overall engine displacement while increasing horsepower over the five-year period.
Table 15. Cubic Inch Displacement for Cars and Light Trucks

\begin{tabular}{|c|c|c|c|}
\hline Model Year & 2005 & 2009 & 5-yr $\Delta$ \\
\hline \multicolumn{4}{|c|}{ Cars } \\
\hline GM & 189 & 190 & $0.5 \%$ \\
\hline FOR & 190 & 185 & $-2.6 \%$ \\
\hline CHR & 186 & 198 & $6.5 \%$ \\
\hline TOY & 137 & 145 & $5.8 \%$ \\
\hline HON & 141 & 141 & $0.0 \%$ \\
\hline NIS & 166 & 158 & $-4.8 \%$ \\
\hline ALL & 166 & 167 & $0.6 \%$ \\
\hline \multicolumn{4}{|c|}{ Light Trucks } \\
\hline GM & 272 & 272 & $0.0 \%$ \\
\hline FOR & 254 & 226 & $-11.0 \%$ \\
\hline CHR & 250 & 246 & $-1.6 \%$ \\
\hline TOY & 221 & 232 & $5.0 \%$ \\
\hline HON & 188 & 187 & $-0.5 \%$ \\
\hline NIS & 258 & 246 & $-4.7 \%$ \\
\hline ALL & 244 & 238 & $-2.5 \%$ \\
\hline
\end{tabular}

Source: EPA, Light-Duty Automotive Technology and Fuel Economy Trends: 1975-2008Manufacturers are using more efficient transmissions

During the past five years, transmissions have evolved along two dimensions to become more efficient: The control system has shifted away from an electric to a lockup or semi-automatic lockup control system, and the number of speeds has shifted away from a four-speed transmission toward a six-speed or variable transmission (Table 16). With two more gears, the six-speed transmission allows the engine to operate at its optimum efficiency for a range of performance further boosting fuel economy.

Several advanced technology transmissions have increased market shares in the past five years: semiautomatic transmission, the lockup clutch, and continuously variable transmission (CVT). A semiautomatic transmission (e.g., "Tiptronic") is a clutchless system that uses electronic sensors, processors, and actuators to shift gears at the command of the driver. Many semi-automatic transmissions can operate similarly to a conventional type of automatic transmission by allowing the transmission's computer to automatically change gear, if, for example the driver was redlining the engine. Early automatic transmissions suffer power losses in the torque converter; however, the use of a lockup clutch that physically links the pump and turbine eliminates slippage and power loss. A CVT, which can smoothly alter its gear ratio by varying the diameter of a pair of belt or chain-linked pulleys, wheels, or cones, is an automatic transmission that is usually as fuel efficient as manual transmissions in city driving. 
Table 16. New Light Vehicle Transmission Characteristics

\begin{tabular}{|c|c|c|c|c|c|}
\hline Model Year & 2005 & 2006 & 2007 & 2008 & 2009 \\
\hline \multicolumn{6}{|c|}{ Control System } \\
\hline Manual & $6.2 \%$ & $6.5 \%$ & $5.6 \%$ & $5.3 \%$ & $5.9 \%$ \\
\hline Automatic & $0.1 \%$ & $0.0 \%$ & $0.0 \%$ & $0.0 \%$ & $0.2 \%$ \\
\hline Lockup & $91.5 \%$ & $90.7 \%$ & $87.1 \%$ & $86.8 \%$ & $85.9 \%$ \\
\hline CVT & $2.3 \%$ & $2.8 \%$ & $7.2 \%$ & $7.9 \%$ & $8.1 \%$ \\
\hline \multicolumn{6}{|c|}{ Speeds } \\
\hline 4 & $56.0 \%$ & $47.7 \%$ & $40.6 \%$ & $38.8 \%$ & $29.7 \%$ \\
\hline 5 & $37.3 \%$ & $39.2 \%$ & $36.2 \%$ & $32.0 \%$ & $33.2 \%$ \\
\hline 6 & $4.1 \%$ & $8.8 \%$ & $14.5 \%$ & $19.5 \%$ & $26.8 \%$ \\
\hline 7 & $0.2 \%$ & $1.4 \%$ & $1.5 \%$ & $1.8 \%$ & $2.3 \%$ \\
\hline Variable & $2.3 \%$ & $2.8 \%$ & $7.2 \%$ & $7.9 \%$ & $8.1 \%$ \\
\hline
\end{tabular}

Source: EPA, Light-Duty Automotive Technology and Fuel Economy Trends: 1975-2009

The companies that started this particular shift toward efficiency are the transmission suppliers. Though most of the manufacturers make their own transmissions, seven of the top 100 global automotive suppliers in 2009 are in the transmission business (Table 17). However, as was the case with several engine suppliers, the U.S. share of global sales for Valeo, ZF Friedrichshafen, and BorgWarner have declined, suggesting that the market growth overseas is outpacing the U.S. growth.

\section{Vehicles are comprised of more advanced materials}

Despite the increase in average vehicle weight, manufacturers are using greater proportions of advanced materials in their vehicles (Table 18). From 2004 to 2008, the percentage of regular steel in an average light vehicle has decreased from $41 \%$ to $40 \%$; while the portion of the car comprised of lightweight materials such as aluminum, magnesium, and plastics/composites has increased by 0.4 percentage points. The overall advanced materials share-defined here as aluminum, magnesium, plastics/composites, and advanced steels-has increased from $30.4 \%$ to $32.0 \%$.

Table 17. Leading Suppliers of Transmissions, Excluding OEMs

\begin{tabular}{|c|c|c|c|c|c|}
\hline \multicolumn{6}{|c|}{ Transmissions } \\
\hline \multicolumn{3}{|c|}{2005} & \multicolumn{3}{|c|}{2009} \\
\hline Company & $\begin{array}{c}\text { Total U.S. } \\
\text { Sales (Mil\$) }\end{array}$ & $\begin{array}{c}\text { U.S. \% of } \\
\text { Global Sales }\end{array}$ & Company & $\begin{array}{c}\text { Total U.S. } \\
\text { Sales (Mil\$) }\end{array}$ & $\begin{array}{c}\text { U.S. \% of } \\
\text { Global Sales }\end{array}$ \\
\hline Magna International Inc & $12,768.0$ & $(56 \%)$ & ZF Friedrichshafen AG & $1,174.8$ & $(10 \%)$ \\
\hline Valeo SA & $1,587.6$ & $(15 \%)$ & BorgWarner, Inc. & $1,109.4$ & $(28 \%)$ \\
\hline ZF Friedrichshafen AG & $1,442.4$ & $(16 \%)$ & Nemak & $1,052.5$ & $(54 \%)$ \\
\hline BorgWarner Inc. & $1,884.7$ & (43\%: & Valeo SA & $1,040.0$ & $(10 \%)$ \\
\hline Timken Co & $1,196.6$ & $(72 \%)$ & Magneti Marelli S.p.A. & 236.6 & $(4 \%)$ \\
\hline Hutchinson SA & 434.0 & $(23 \%)$ & Hyundai-WIA Corp. & 19.1 & $(1 \%)$ \\
\hline \multicolumn{6}{|c|}{$\begin{array}{l}\text { Source: "Top } 100 \text { Global Suppliers 2009" and "Top } 100 \text { Global Suppliers 2005", both by Automotive News. Note: data } \\
\text { include both light and heavy vehicle. Shares listed to not represent the actual share of transmissions, but all of } \\
\text { North American sales. }\end{array}$} \\
\hline
\end{tabular}


Table 18. Average Materials Content of North American Light Vehicles

\begin{tabular}{|l|c|c|c|c|c|}
\hline \multicolumn{1}{|c|}{ Model Year } & $\mathbf{2 0 0 4}$ & $\mathbf{2 0 0 5}$ & $\mathbf{2 0 0 6}$ & $\mathbf{2 0 0 7}$ & $\mathbf{2 0 0 8}$ \\
\hline Regular Steel & $41.0 \%$ & $40.7 \%$ & $40.1 \%$ & $40.3 \%$ & $40.0 \%$ \\
\hline High Strength Steel & $11.9 \%$ & $12.2 \%$ & $12.4 \%$ & $12.7 \%$ & $12.9 \%$ \\
\hline Stainless Steel & $1.7 \%$ & $1.8 \%$ & $1.8 \%$ & $1.8 \%$ & $1.8 \%$ \\
\hline Other Steel & $0.8 \%$ & $0.9 \%$ & $0.9 \%$ & $0.8 \%$ & $0.8 \%$ \\
\hline Aluminum & $7.7 \%$ & $7.9 \%$ & $8.0 \%$ & $7.7 \%$ & $7.7 \%$ \\
\hline Magnesium Castings & $0.2 \%$ & $0.2 \%$ & $0.2 \%$ & $0.2 \%$ & $0.3 \%$ \\
\hline $\begin{array}{l}\text { Plastics and Plastic } \\
\text { Composites }\end{array}$ & $8.1 \%$ & $8.3 \%$ & $8.4 \%$ & $8.1 \%$ & $8.4 \%$ \\
\hline Other Material & $28.5 \%$ & $28.1 \%$ & $28.3 \%$ & $28.2 \%$ & $28.0 \%$ \\
\hline All Advanced Materials & $30.4 \%$ & $31.2 \%$ & $31.6 \%$ & $31.4 \%$ & $32.0 \%$ \\
\hline Source:
\end{tabular}

Source: 2008 Ward's Motor Vehicle Facts and Figures

Several companies have shown exceptional investment in advanced materials. Audi's A8 Space Frame, weighing only 113 pounds (nearly 90 pounds less than a steel body shell of the same type), set new standards in its market segment. The Jaguar XJ11 also features an allaluminum chassis. Corvettes feature aluminum frames, magnesium engine cradles, a magnesium roof, and carbonfiber bumpers. The Mercedes 300 SLR features magnesium-alloy bodywork, and the A-Series features advanced composite-fiber materials.

Materials suppliers are numerous among the top 100 global suppliers; three of the top 100 have a specialty in plastics and polymers, while two have a specialty in aluminum components (Table 19).

Raw-materials manufacturers are one further step removed from OEMs than the suppliers. The manufacturers of advanced steel recognized as world leaders include Arcelor-Mital, Nucor, U.S. Steel, POSCO, and ThyssenKrupp; recognized leading aluminum manufacturers include ALCOA, Novelis, Kaiser, Corus (nonU.S.); recognized leaders in composites include Meridian, MSG, Bayer, and Lincoln Composites (non-U.S.); and leaders in magnesium manufacture include Magnesium Elektron, NEMAK, and Luoyang (non-U.S.).

DOE is recognized as a leading supporter of research for all of the aforementioned advanced automotive materials. Many companies are performing research on materials with assistance from DOE. For example, ArcelorMittal, U.S. Steel, and most of the large OEMs conduct R\&D in advanced steel; ALCOA, Novelis, and Audi conduct R\&D in aluminum; AF Materials Lab, Boeing, Oak Ridge National Laboratory (ORNL), the University of Delaware, and Mercedes-Benz conduct R\&D in composites; and Magnesium Elektron, Ford, and GM conduct R\&D in magnesium.

Demonstrations in mass-produced vehicles within the past five years include advanced steel in front ends and door-intrusion beams, aluminum in liftgates, composites in truck beds, and magnesium in instrument panels.

\section{More vehicles feature gasoline direct injection (GDi)}

The major advantages of a gasoline direct injection (GDi) engine are increased fuel efficiency and high power output. In addition, the cooling effect of the injected fuel and the more evenly dispersed mixtures allow for more aggressive ignition timing curves. In 2004, Isuzu Motors produced the first GDi engines sold in mainstream American vehicles: GDi came standard on the 2004 Axiom and optional on the 2004 Rodeo. General Motors introduced a $155 \mathrm{hp}(116 \mathrm{~kW})$ version of the $2.2 \mathrm{~L}$ Ecotec used in the Opel Vectra and Signum in 2004; a 2.0 L Ecotec with Variable Valve Timing technology for the new Opel GT, Pontiac Solstice GXP, and the Saturn Sky Red Line in 2005; and expanded the use of that engine to the Super Sport versions of the Chevrolet Cobalt and the Chevrolet HHR in 2007. Also in 2007, an engine featuring direct injection became available in the second-generation Cadillac CTS. Ford's EcoBoost engines, first produced in 2009, combine GDi with turbocharging to allow the engine to have fewer cylinders without a performance penalty to the consumer. Engines equipped with EcoBoost technology are designed to deliver power and torque consistent with larger displacement, naturally aspirated engines while achieving approximately $20 \%$ better fuel efficiency and $15 \%$ reduced greenhouse emissions than these same engines.

Mazda uses its own version of direct-injectionreferred to as Direct Injection Spark Ignition (DISI) - in the Mazdaspeed 6 / Mazda 6 MPS, the CX-7 sport-utility, and the Mazdaspeed 3. Additional models using GDi technology include the Audi TT, A4, A6; second-generation Mini Cooper S; and the Volkswagen GT, Jetta, and Passat (with 2.0L engines).

\section{Volkswagen is the only volume seller of light diesels in the United States}

Diesel vehicles are more powerful and fuel efficient than similar-sized gasoline engines. Because of this, manufacturers may begin offering more light vehicles with diesel engines. Since 2004, Volkswagen (VW) has been the only volume seller of diesel engines; the company offered a 1.9L engine in the Golf, Jetta, and Beetle subcompact vehicles. Sales were in the 15,000 to 30,000 range annually, but the diesel engine option was suspended in 2006 with the end of the Bin 9/10 certification options (see Table 39 for information on light-vehicle emission standards). Mercedes offered one model, the E320, but this was sold in small volumes $(\sim 5,000 / \mathrm{yr})$ and also discontinued after 2006. Energy and Environmental Analysis (EEA) reports that Jeep also offered one model in 2006. 
Table 19. Leading Suppliers of Advanced Materials

Leading Suppliers in Automotive Steel

\begin{tabular}{|l|c|l|c|}
\hline \multicolumn{1}{|c|}{ Company } & $\begin{array}{c}2005 \\
\text { Million Metric Tons of } \\
\text { Crude Steel Output }\end{array}$ & Company & $\begin{array}{c}\text { Million Metric Tons of } \\
\text { Crude Steel Output }\end{array}$ \\
\hline Mittal Steel & 63.0 & ArcelorMittal & 77.5 \\
\hline Arcelor & 46.7 & Baosteel & 31.3 \\
\hline Nippon Steel & 32.0 & POSCO & 31.1 \\
\hline POSCO & 30.5 & Nippon Steel & 26.5 \\
\hline JFE & 29.9 & JFE & 25.8 \\
\hline
\end{tabular}

\begin{tabular}{|c|c|c|c|c|c|}
\hline \multicolumn{3}{|c|}{2005} & \multicolumn{3}{|c|}{2009} \\
\hline Company & $\begin{array}{c}\text { Total U.S. } \\
\text { Sales (Mil\$) }\end{array}$ & $\begin{array}{c}\text { U.S. \% of } \\
\text { Global } \\
\text { Sales }\end{array}$ & Company & $\begin{array}{c}\text { Total U.S. } \\
\text { Sales (Mil\$) }\end{array}$ & $\begin{array}{c}\text { U.S. \% of } \\
\text { Global } \\
\text { Sales }\end{array}$ \\
\hline DuPont & $2,875.0$ & $(50 \%)$ & Flex-N-Gate & $2,238.1$ & $(85 \%)$ \\
\hline Collins \& Aikman Corp. & $2,800.0$ & $(100 \%)$ & DuPont & $1,800.0$ & $(45 \%)$ \\
\hline Plastic Omnium Co & 602.5 & $(28 \%)$ & Toyoda Gosei Co & $1,040.0$ & $(20 \%)$ \\
\hline Dow Automotive & 593.8 & $(43 \%)$ & Bayer MaterialScience & 451.2 & $(24 \%)$ \\
\hline & & & Plastic Omnium Co & 449.4 & $(20 \%)$ \\
\hline & & & Magneti Marelli S.p.A. & 236.6 & $(4 \%)$ \\
\hline \multicolumn{3}{|c|}{2005} & \multicolumn{3}{|c|}{2009} \\
\hline \multirow[t]{2}{*}{ Teksid Aluminum } & 485.6 & $(39 \%)$ & Nemak & $1,052.5$ & $(54 \%)$ \\
\hline & & & Nissin Kogyo Co. & 263.1 & $(21 \%)$ \\
\hline
\end{tabular}

According to EEA, VW sells its 2009 diesel at about a $\$ 2,000$ increment over gasoline models, which, when a $\$ 1,300$ tax credit is applied, implies a net cost to the consumer of about $\$ 700$ (see Table 41 for information on diesel tax credits). Mercedes prices its diesels at only $\$ 1,500$ over the gasoline model. When this incremental price is considered in conjunction with a $\$ 900$ subsidy for the $\mathrm{M}$ class, $\$ 1,550$ for the $\mathrm{R}$ class, and $\$ 1,800$ for the $\mathrm{G}$ series, the consumer sees a very low-even negative-net incremental cost. The diesel engine's performance is comparable to similar engine-size gasoline models.

Chrysler sold the 45-state Bin 8-certified diesel Jeep Grand Cherokee, which is equipped with Mercedes 3L V6 and the Bluetec after-treatment in model years 2007 and 2008, but stopped selling this product after it was spun off from Daimler. Cummins' new 4.2L V6 will be used for Chrysler's light-truck products, starting with the Dodge Ram.
More diesel light vehicles are becoming available. BMW and Audi join VW and Mercedes-Benz in the list of manufacturers with diesel vehicles available in MY 2010 (Table 20). 
Table 20. MY 2010 Diesel Vehicles

Audi A3
Audi Q7
BMW 335d
BMW X5 xDrive35d
Mercedes-Benz GL350 Blutec
Mercedes-Benz ML350 Blutec
Mercedes-Benz R350 Blutec
VW Golf
VW Jetta
VW Jetta SportWagen
VW Touareg

Source: DOE/EPA, Fueleconomy.Gov

\section{Flex-fuel vehicles make their way into the population}

Flex-fuel vehicles are designed to run on gasoline or a blend of up to 85\% ethanol (E85). There are more than eight million flex-fuel vehicles (FFVs) in operation (Figure 20). These vehicles can be fueled by gasoline, E85 (a fuel made from $85 \%$ ethanol and 15\% gasoline), or any combination of the two. Manufacturers first started making FFVs in the late 1990s; by 2005, there were 24 different FFV models on the market (Table 21). In 2009, however, there were 36 different FFV models available, most of them from GM, Chrysler, and Ford. In summer 2007, the three U.S. OEMs pledged to President Bush that they would make half of their vehicles FFVs by 2012. Toyota and Mitsubishi have joined Nissan and MercedesBenz as the only foreign manufacturers to produce FFVs in 2009. In 2010, Toyota added the Sequoia to the list of FFVs.

\section{Figure 20. Number of Flex-fuel Vehicles in Operation}

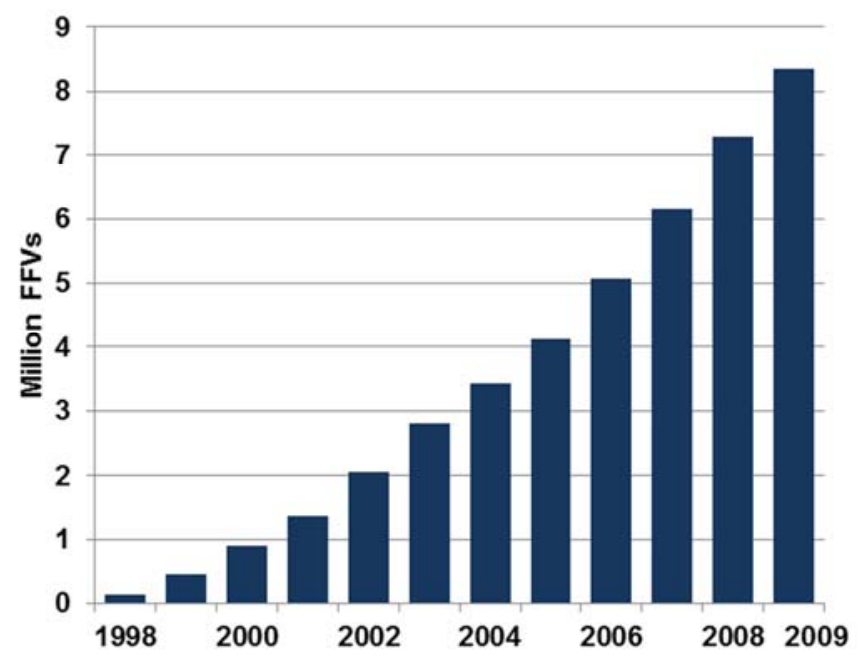

Source: Alternative Fuels and Advanced Vehicles Data Center
Table 21. Flex-fuel Vehicle Models

\begin{tabular}{|l|r|r|}
\hline \multicolumn{1}{|c|}{$\begin{array}{c}\text { Model } \\
\text { Year }\end{array}$} & 2005 & \multicolumn{1}{c|}{\begin{tabular}{l} 
2009 \\
\hline GMC
\end{tabular}} \\
\hline TOY & 7 & 14 \\
\hline FMC & 0 & 1 \\
\hline CHR & 6 & 7 \\
\hline HON & 5 & 10 \\
\hline NIS & 0 & 0 \\
\hline OTHER & 1 & 2 \\
\hline ALL & 5 & 2 \\
\hline
\end{tabular}

Source: Alternative Fuels and Advanced Vehicles Data Center

\section{Toyota sells the most hybrid electric vehicles}

Hybrid electric vehicles combine the benefits of gasoline engines and electric motors to improve fuel economy and/or increase power. The number of HEVs sold has increased from its 2005 level (Table 22 and Figure 21). Although HEV sales have grown during the five-year period, HEVs were not immune to the new car market decline beginning in 2008. In 2009, only five hybrid models experienced an increase in sales from 2008. The number of models available expanded from eight in 2005 to 23 in 2009. New HEV models that arrived in 2009 include the Dodge Durango, Ford Fusion, Mercury Milan, Lexus HS 250h, and Sierra/Silverado. Despite the increase in make and model availability, domestic manufacturer production is still limited: most HEVs are not produced by the Big 3 (General Motors, Ford, or Chrysler). Of the 290,000 HEVs sold in 2009 , only 50,000 (17\% of total HEV sales) were manufactured by the Big 3 . The Toyota Prius sales have consistently comprised about half of the total sales of HEVs.

\section{HEV incremental price has changed but has not decreased definitively}

The average price of a hybrid vehicle has increased during the past five years, largely due to the introduction of a wider array of luxury hybrids (Table 23). But the average incremental price-the additional price of a hybrid over its non-hybrid counterpart-decreased from 2008 to 2009. In general, an HEV incremental price depends on the sophistication level of the hybrid system. This price generally is reflected in an increased price to the consumer of about $\$ 5,000$ to $\$ 8,000$ relative to a nonhybrid base model. Generally, incremental price will decrease as the technology matures and is less costly to manufacture. The increase in the average incremental price for 2009 is caused by the large increase in the available hybrid models. 
Table 22. Hybrid Electric Vehicle Sales

\begin{tabular}{|c|c|c|c|c|c|}
\hline Calendar Year & 2005 & 2006 & 2007 & 2008 & 2009 \\
\hline Honda Insight & 666 & 722 & 0 & 0 & 20,572 \\
\hline Toyota Prius & 107,897 & 106,971 & 181,221 & 158,574 & 139,682 \\
\hline Honda Civic & 25,864 & 31,251 & 32,575 & 31,297 & 15,119 \\
\hline Ford Escape & 18,797 & 20,149 & 21,386 & 17,173 & 14,787 \\
\hline Honda Accord & 16,826 & 5,598 & 3,405 & 196 & 0 \\
\hline Lexus RX400h & 20,674 & 20,161 & 17,291 & 15,200 & 14,464 \\
\hline Toyota Highlander & 17,989 & 31,485 & 22,052 & 19,441 & 11,086 \\
\hline Mercury Mariner & 998 & 3,174 & 3,722 & 2,329 & 1,693 \\
\hline Lexus GS 450h & & 1,784 & 1,645 & 678 & 469 \\
\hline Toyota Camry & & 31,341 & 54,477 & 46,272 & 22,887 \\
\hline Nissan Altima & & & 8,388 & 8,819 & 9,357 \\
\hline Saturn Vue & & & 4,403 & 2,920 & 2,656 \\
\hline Lexus LS600hL & & & 937 & 907 & 258 \\
\hline Saturn Aura & & & 772 & 285 & 527 \\
\hline Chevy Tahoe & & & & 3,745 & 3,300 \\
\hline GMC Yukon & & & & 1,610 & 1,933 \\
\hline Chevy Malibu & & & & 2,093 & 4,162 \\
\hline Cadillac Escalade & & & & 801 & 1,958 \\
\hline Chrysler Aspen & & & & 46 & 33 \\
\hline Dodge Durango & & & & & 9 \\
\hline Ford Fusion & & & & & 15,554 \\
\hline Mercury Milan & & & & & 1,468 \\
\hline Lexus HS 250h & & & & & 6,699 \\
\hline Sierra/Silverado & & & & & 1,598 \\
\hline Total & 209,711 & 252,636 & 352,274 & 312,386 & 290,271 \\
\hline
\end{tabular}

Figure 21. Hybrid Electric Vehicle Sales

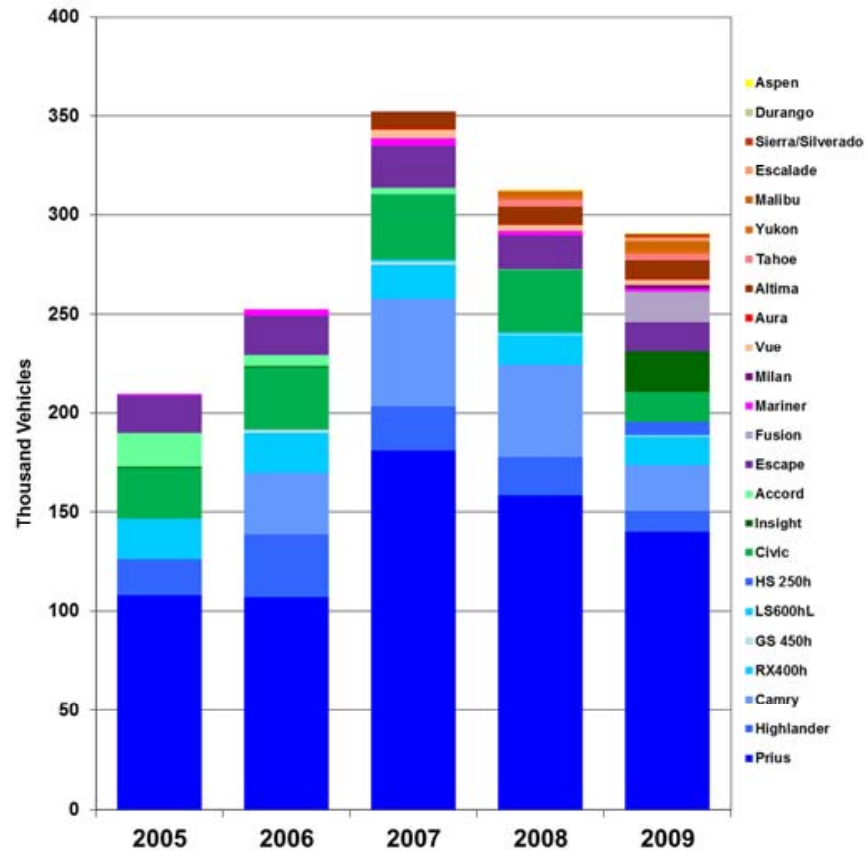

Source: Alternative Fuels and Advanced Vehicles Data Center
Table 24 shows incremental prices for all hybrid models for which a comparison could be made against a nonhybrid. The incremental price for some models appears to increase in some years. This change could be the result of a change in the number of luxury options available, which could increase the total vehicle price and obscure the price change attributable to only the hybrid system. 
Table 23. New Hybrid Vehicle Price

\begin{tabular}{|l|r|r|r|r|r|}
\hline \multicolumn{1}{|c|}{ Model Year } & $\mathbf{2 0 0 6}$ & $\mathbf{2 0 0 7}$ & $\mathbf{2 0 0 8}$ & $\mathbf{2 0 0 9}$ & $\mathbf{2 0 1 0}$ \\
\hline Cadillac Escalade & - & - & - & 80,285 & 80,575 \\
\hline Chevy Malibu & - & - & 23,895 & 25,555 & - \\
\hline ChevySilverado & & 28,813 & - & 42,663 & 43,080 \\
\hline Chevy Tahoe & - & - & 50,993 & 51,858 & 52,123 \\
\hline Chrysler Aspen & - & - & - & 45,270 & - \\
\hline Dodge Durango & - & - & - & 45,040 & - \\
\hline Ford Escape & 27,713 & 26,458 & 28,330 & 31,685 & 31,990 \\
\hline Ford Fusion & - & - & - & - & 27,950 \\
\hline GMC Sierra & 29,053 & 29,290 & - & 43,033 & 43,450 \\
\hline GMC Yukon & - & - & 51,450 & 56,000 & 56,265 \\
\hline Honda Accord & 30,990 & 31,090 & 22,600 & - & - \\
\hline Honda Civic & 22,150 & 22,600 & 22,600 & 23,650 & 23,800 \\
\hline Honda Insight & 20,430 & - & - & - & 20,550 \\
\hline Lexus GS 450h & - & 54,900 & 55,800 & 56,550 & 57,450 \\
\hline Lexus HS 250h & - & - & - & - & 35,980 \\
\hline Lexus LS600h & - & - & 104,900 & 106,035 & 108,800 \\
\hline Lexus RX400h & 45,360 & 41,880 & 42,780 & - & 43,480 \\
\hline Mazda Tribute & - & - & 27,440 & 31,310 & - \\
\hline Mercury Mariner & 29,225 & 27,950 & 29,035 & 30,965 & 30,980 \\
\hline Mercury Milan & - & - & - & - & 28,180 \\
\hline Nissan Altima & - & 24,990 & 25,480 & 26,650 & 26,780 \\
\hline Saturn Aura & - & 22,045 & 23,900 & 26,325 & - \\
\hline Saturn Vue & - & 22,870 & 25,645 & 28,160 & - \\
\hline Toyota Camry & - & 26,200 & 25,200 & 26,150 & 26,150 \\
\hline Toyota Highlander & 36,160 & 34,250 & 37,325 & 37,860 & 38,060 \\
\hline Toyota Prius & 21,725 & 22,623 & 22,635 & 23,135 & 24,735 \\
\hline
\end{tabular}

Source: AOL Autos

Table 24. Incremental Price of New Hybrid Vehicles

\begin{tabular}{|c|c|c|c|c|c|}
\hline \multicolumn{6}{|c|}{ HEV Incremental Price } \\
\hline Model Year & 2006 & 2007 & 2008 & 2009 & 2010 \\
\hline Cadillac Escalade & - & - & - & 6,525 & 6,525 \\
\hline Chevy Malibu & - & - & 398 & 1,313 & - \\
\hline ChevySilverado & - & 3,313 & - & 12,298 & 11,768 \\
\hline Chevy Tahoe & - & - & 13,898 & 7,675 & 6,675 \\
\hline Chrysler Aspen & - & - & - & 9,348 & - \\
\hline Dodge Durango & - & - & - & 11,083 & - \\
\hline Ford Escape & 4,683 & 3,608 & 5,668 & 7,633 & 7,793 \\
\hline Ford Fusion & - & - & - & - & 3,925 \\
\hline GMC Sierra & 1,745 & 1,808 & - & 11,335 & 9,808 \\
\hline GMC Yukon & - & - & 9,038 & 10,583 & 6,145 \\
\hline Honda Accord & 8,178 & 8,028 & - & - & - \\
\hline Honda Civic & 2,650 & 2,900 & 445 & 3,403 & 3,403 \\
\hline Lexus GS $450 \mathrm{~h}$ & - & - & - & - & - \\
\hline Lexus HS $250 \mathrm{~h}$ & - & - & - & - & - \\
\hline Lexus LS 600h & - & - & - & - & - \\
\hline Lexus RX 400h & - & - & - & - & - \\
\hline Mazda Tribute & - & - & 4,485 & 7,628 & - \\
\hline Mercury Mariner & 5,143 & 3,955 & 5,143 & 5,883 & 5,510 \\
\hline Mercury Milan & - & - & - & - & 3,010 \\
\hline Nissan Altima & - & 1,815 & 1,835 & 2,010 & 1,780 \\
\hline Saturn Aura & - & - & 860 & 1,373 & - \\
\hline Saturn Vue & - & 2,278 & 233 & 1,053 & - \\
\hline Toyota Camry & - & 2,955 & 1,855 & 2,230 & 1,930 \\
\hline Toyota Highlander & 7,965 & 5,705 & 6,400 & 3,250 & 7,798 \\
\hline Average & 5,061 & 3,637 & 4,188 & 6,154 & 5,852 \\
\hline
\end{tabular}

Source: AOL Autos 


\section{Heavy- and medium-truck sales have declined significantly}

The sales of heavy and medium trucks have gone through two distinct phases during the past five years: moderate growth through 2006, followed by dramatic decline (Figure 22). Although the total-sale composition changed somewhat by class, the total sales of heavy and medium trucks increased slightly or changed little from 2005 through 2006. In 2007, heavy-truck sales had a sharp reduction, followed by declines in 2008 and 2009. By 2009, 53\% fewer heavy and medium vehicles were sold than five years earlier (Table 25).

Figure 22. Medium and Heavy Truck Retail Sales

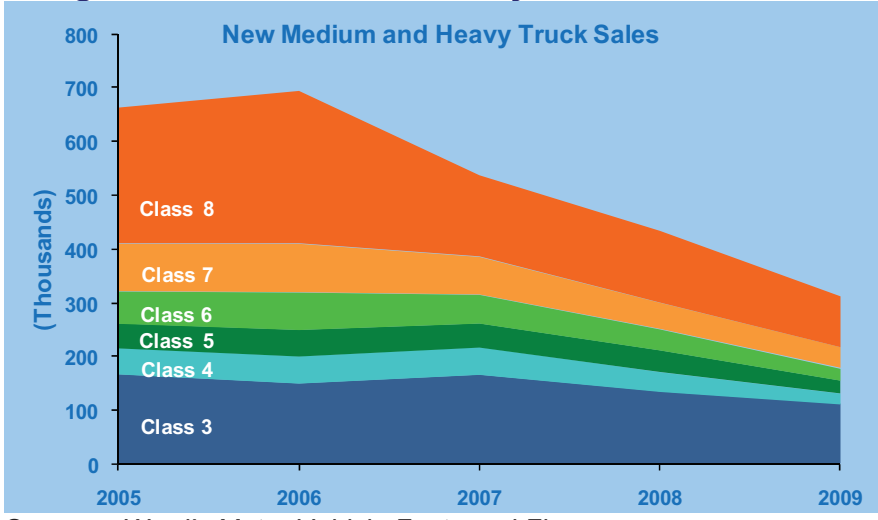

Source: Ward's Motor Vehicle Facts and Figures
Sales of heavy trucks have been the hardest hit. Beginning in 2007, heavy-truck sales plummeted: Total sales of class 8 heavy trucks in 2007 were less than half that of the previous year, with declines continuing to 2009 . Class 7 heavy trucks experienced a less-drastic, but still sharp, decline. Sales of heavy trucks continued to decline in 2008 and 2009. Unlike sales of heavy trucks, mediumtruck sales continued to increase slightly or stagnate in 2007 relative to their 2006 volumes, then declined drastically beginning in 2008 and continued to fall in 2009.

\section{GM has significantly increased its class 3 truck market penetration}

Class 3 trucks include large pickups often used in ranching and farming, hauling horses, towing motor homes, and recreation. The primary manufacturers of these trucks are the three domestic manufacturers. The market share among these makers shifted considerably during the past five years (Figure 23 and Table 26). GM has increased its medium-truck market share from $2 \%$ in 2005 to $22 \%$ in 2009 . Chrysler sold $32 \%$ more class 3 trucks in 2009 than in 2005. Ford, however, accounted for $74 \%$ of sales in 2005 , but dropped to less than $35 \%$ of sales in 2009 .

The recent downturn in the economy heavily affected 2008 and 2009 sales. From 2005 to 2009, total sales declined by $33 \%$.

Table 25. Medium and Heavy Truck Retail Sales

\begin{tabular}{|c|r|r|r|r|r|r|}
$\begin{array}{c}\text { Calendar } \\
\text { Year }\end{array}$ & \multicolumn{1}{|c|}{$\mathbf{2 0 0 5}$} & $\mathbf{2 0 0 6}$ & \multicolumn{1}{|c|}{$\mathbf{2 0 0 7}$} & $\mathbf{2 0 0 8}$ & $\mathbf{2 0 0 9}$ & $\mathbf{5 - y r} \mathbf{\Delta}$ \\
\hline Class 3 & 166,856 & 149,844 & 165,896 & 134,839 & 111,704 & $-33 \%$ \\
\hline Class 4 & 48,493 & 50,286 & 50,991 & 36,374 & 19,858 & $-59 \%$ \\
\hline Class 5 & 46,278 & 49,466 & 44,922 & 40,300 & 23,942 & $-48 \%$ \\
\hline Class 6 & 60,154 & 70,029 & 53,789 & 39,397 & 22,001 & $-63 \%$ \\
\hline Class 7 & 88,858 & 90,792 & 70,426 & 48,880 & 39,087 & $-56 \%$ \\
\hline Class 8 & 252,792 & 284,008 & 150,965 & 133,473 & 94,798 & $-62 \%$ \\
\hline T0TAL & $\mathbf{6 6 3 , 4 3 1}$ & $\mathbf{6 9 4 , 4 2 5}$ & $\mathbf{5 3 6 , 9 8 9}$ & $\mathbf{4 3 3 , 2 6 3}$ & $\mathbf{3 1 1 , 3 9 0}$ & $\mathbf{- 5 3 \%}$ \\
\hline
\end{tabular}

Source: Ward's Motor Vehicle Facts and Figures

Table 26. Class 3 Truck Retail Sales, by Manufacturer

\begin{tabular}{|c|c|c|c|c|c|c|}
\hline Calendar Year & 2005 & 2006 & 2007 & 2008 & 2009 & 5 -yr $\Delta$ \\
\hline Chrysler & 35,038 & 36,057 & 46,553 & 29,638 & 46,088 & $32 \%$ \\
\hline Ford & 122,903 & 105,955 & 81,155 & 60,139 & 38,664 & $-69 \%$ \\
\hline Freightliner* & 14 & 0 & 0 & 0 & 0 & $-100 \%$ \\
\hline General Motors & 2,788 & 2,578 & 33,507 & 41,559 & 24,760 & $788 \%$ \\
\hline International & 0 & 0 & 0 & 609 & 341 & \\
\hline Isuzu & 5,167 & 4,929 & 4,350 & 2,568 & 1,473 & $-71 \%$ \\
\hline Mitsubishi-Fuso & 670 & 93 & 52 & 202 & 275 & $-59 \%$ \\
\hline Nissan Diesel & 276 & 232 & 279 & 112 & 0 & $-100 \%$ \\
\hline Sterling & 0 & 0 & 0 & 12 & 103 & \\
\hline Total & 166,856 & 149,844 & 165,896 & 134,839 & 111,704 & $-33 \%$ \\
\hline
\end{tabular}

* Freightliner/Sterling/Western Star.

Source: Ward's Motor Vehicle Facts and Figures 
Table 27. Class 4-7 Truck Sales, by Manufacturer

\begin{tabular}{|c|c|c|c|c|c|c|}
\hline Calendar Year & 2005 & 2006 & 2007 & 2008 & 2009 & 5-yr $\Delta$ \\
\hline Ford & 61,358 & 69,070 & 70,836 & 46,454 & 26,602 & $-57 \%$ \\
\hline Freightliner* & 51,639 & 51,357 & 42,061 & 30,809 & 20,450 & $-60 \%$ \\
\hline GM & 45,144 & 41,340 & 34,164 & 24,828 & 12,255 & $-73 \%$ \\
\hline Hino & 4,290 & 6,203 & 5,448 & 4,917 & 2,980 & $-31 \%$ \\
\hline International & 0 & 61,814 & 40,268 & 35,022 & 26,237 & \\
\hline Isuzu & 10,620 & 10,822 & 9,639 & 6,157 & 3,530 & $-67 \%$ \\
\hline Kenworth & 3,874 & 5040 & 4,239 & 3,710 & 3,013 & $-22 \%$ \\
\hline Mitsubishi-Fuso & 4,842 & 5,967 & 5,218 & 2,136 & 1,283 & $-74 \%$ \\
\hline Navistar & 54,895 & 0 & 0 & 0 & 0 & $-100 \%$ \\
\hline Nissan Diesel & 2,382 & 2,551 & 2,080 & 1,273 & 0 & $-100 \%$ \\
\hline Peterbilt & 4,739 & 6,307 & 5,009 & 3,792 & 2,839 & $-40 \%$ \\
\hline Sterling & 0 & 102 & 578 & 467 & 609 & \\
\hline UD Trucks & 0 & 0 & 0 & 0 & 888 & \\
\hline Total & 243,783 & 260,573 & 219,540 & 159,565 & 100,686 & $-59 \%$ \\
\hline
\end{tabular}

${ }^{\star}$ Freightliner/Sterling/Western Star.

Source: Ward's Motor Vehicle Facts and Figures

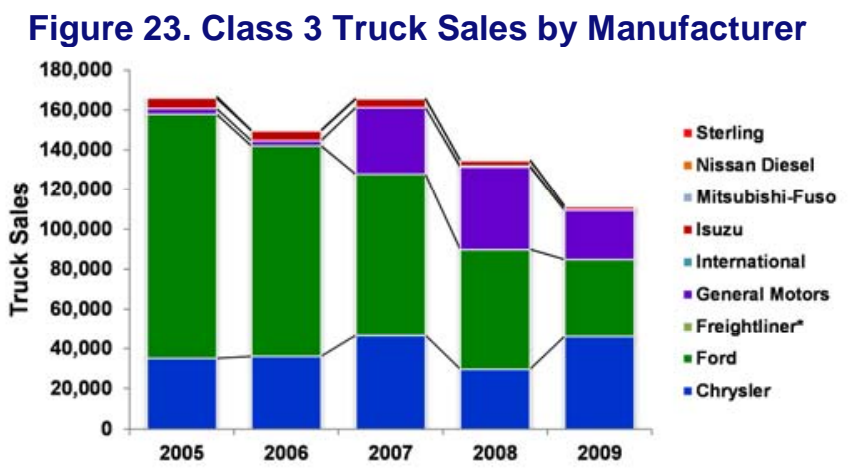

${ }^{*}$ Freightliner/Sterling/Western Star

Source: Ward's Motor Vehicle Facts and Figures

\section{Class 4-7 truck sales have declined steadily since 2006}

Class 4-7 trucks are dedicated commercial work trucks, such as parcel-post delivery trucks and large pickups or utility trucks with large bodies for equipment. The major manufacturers of these trucks have not changed significantly during the past five years; however, UD Trucks entered the market in 2009, while Nissan Diesel exited. For these four classes combined, Ford and International were each responsible for one-quarter of the sales in 2009; Freightliner held a 20\% market share and General Motors was 12\% (Figure 24 and Table 27).
Figure 24. Class 4-7 Truck Retail Sales by Manufacturer

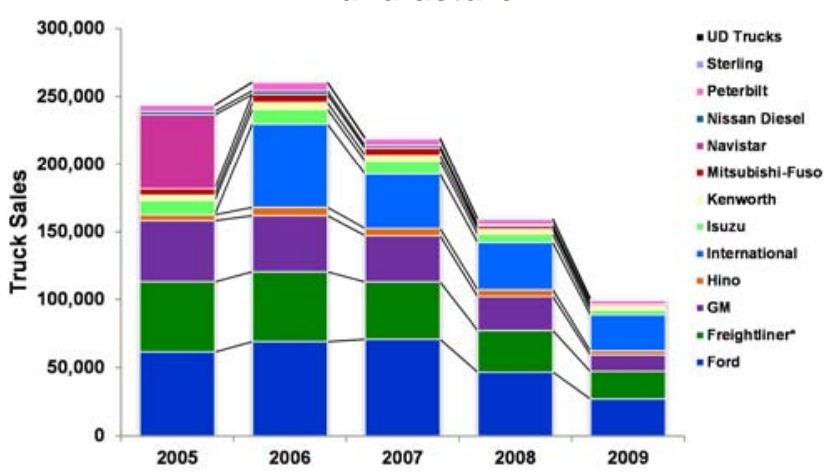

${ }^{\star}$ Freightliner/Sterling/Western Star.

Source: Ward's Motor Vehicle Facts and Figures

Sales volumes decreased notably in 2007 from their 2006 levels, probably because of new, more stringent diesel emission technologies-and a corresponding price increase and uncertainty-in response to the introduction of more stringent standards. General economic downturns are likely to blame for the low sales volumes in 2008 and 2009. Sales in 2009 were 59\% lower than in 2005.

\section{Class 8 truck sales dropped $47 \%$ in 2007 and continue to decline}

Class 8 trucks are the largest trucks (GVW > 33,000 lbs). This class includes single-unit and tractortrailer equipment typically used for long-haul freight transportation. The major manufacturers of these trucks 
have been consistent for the past five years. Sales shares have not changed significantly among most manufacturers with one exception: Freightliner's market share declined seven percentage points since 2005 and International's increased (Figure 25 and Table 28).

Sales volumes decreased by $47 \%$ in 2007 from their 2006 levels perhaps due in part to the introduction of costly advanced diesel emission-control technologies. Nearly $100 \%$ of class 8 trucks operate on diesel, so nearly all class 8 trucks incorporated emissions-control devices that raised the vehicle price in 2007. Sales did not recover in 2008 and declined further in 2009 due to the economic recession, which affected all sectors of the economy. The downturn in sales adversely affected most manufacturers similarly: As Table 26 shows, most companies saw declines between $55 \%$ and $75 \%$ from 2005 .

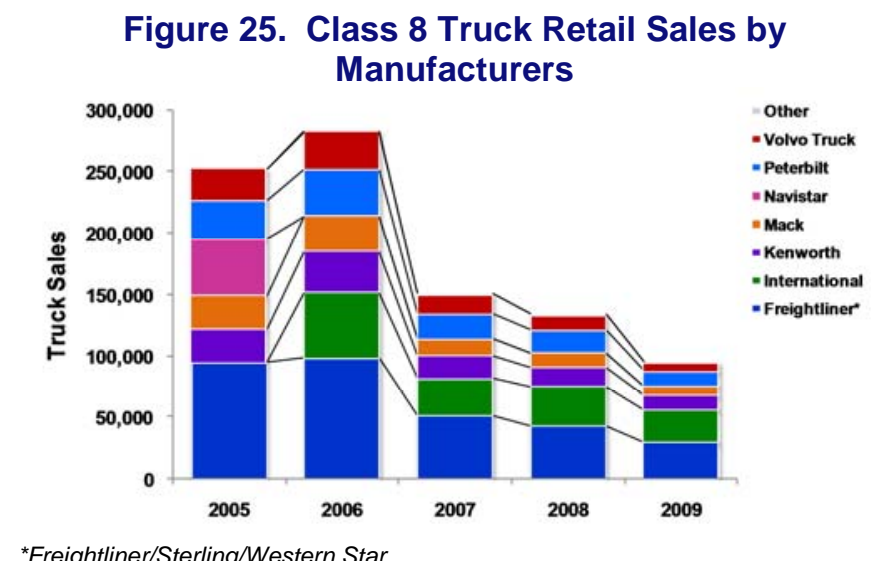

${ }^{\star}$ Freightliner/Sterling/Western Star.

Source: Ward's Motor Vehicle Facts and Figures

\section{Diesel engine sales have decreased significantly}

Table 29 shows that the factory sales of diesel engines manufactured for heavy and medium trucks declined from 604,000 in 2005 to 221,000 in 2009.

Most medium- and heavy-truck engines now use exhaust-heat recovery, either through turbocharging or turbocompounding. Turbocharging is the first stage of exhaust heat recovery, whereby exhaust energy is used to boost fresh intake-air charge. Caterpillar, Cummins, Detroit Diesel, Navistar, and Mack/Volvo have employed such a process for the past several decades. Detroit Diesel began using turbocompounding on approximately $15 \%$ of its engines in 2008. Turbocompounding is a second, additional stage of exhaust heat recovery, in which exhaust gas is converted to mechanical energy that goes directly to the crankshaft.

\section{Medium and heavy hybrid trucks are on the market}

The first line production of commercial diesel electric hybrid trucks was the International DuraStar Hybrid which began production 2007. Hybrid electric medium trucks achieve a fuel economy of $35 \%-40 \%$ greater than a non-hybrid medium truck according to a study conducted by Navistar in 2008 (the hybrid achieved $6.8 \mathrm{mpg}$ while the conventional drive truck achieved only $4.8 \mathrm{mpg}$ ). Hybrid electric medium trucks offer the on-road fuel economy increase that light vehicles offer, and, in some cases, they also provide a means for performing relevant work-such as power tools on a utility truck-without using the engine.

Table 28. Class 8Truck Retail Sales, by Manufacturer

\begin{tabular}{|l|r|l|l|l|r|r|}
\hline Calendar Year & $\mathbf{2 0 0 5}$ & $\mathbf{2 0 0 6}$ & $\mathbf{2 0 0 7}$ & $\mathbf{2 0 0 8}$ & $\mathbf{2 0 0 9}$ & $\mathbf{5}$-yr $\boldsymbol{\Delta}$ \\
\hline Freightliner* & 94,900 & 98,603 & 51,706 & 42,639 & 29,576 & $-69 \%$ \\
\hline International & 0 & 53,373 & 29,675 & 32,399 & 26,581 & \\
\hline Kenworth & 27,153 & 33,091 & 19,299 & 15,855 & 11,652 & $-57 \%$ \\
\hline Mack & 27,303 & 29,524 & 13,438 & 11,794 & 7,626 & $-72 \%$ \\
\hline Navistar & 46,093 & 0 & 0 & 0 & 0 & $-100 \%$ \\
\hline Peterbilt & 30,274 & 37,322 & 19,948 & 17,613 & 12,277 & $-59 \%$ \\
\hline Volvo Truck & 26,446 & 30,716 & 16,064 & 13,061 & 7,066 & $-73 \%$ \\
\hline Other & 623 & 1,379 & 835 & 112 & 20 & $-97 \%$ \\
\hline Total & $\mathbf{2 5 2 , 7 9 2}$ & $\mathbf{2 8 4 , 0 0 8}$ & $\mathbf{1 5 0 , 9 6 5}$ & $\mathbf{1 3 3 , 4 7 3}$ & $\mathbf{9 4 , 7 9 8}$ & $\mathbf{- 6 2 \%}$ \\
\hline
\end{tabular}

There are 17 models from eight different manufacturers of hybrid cargo trucks on the market today (Table 30). Two of those, Ford and Navistar, also manufacture fully electric trucks, along with Modec and Smith Electric Vehicles. Most of the hybrid trucks available are dieselfueled and are used for a variety of purposes, ranging from delivery vehicles to long-haul trucks.

${ }^{*}$ Freightliner/Sterling/Western Star.

Source: Ward's Motor Vehicle Facts and Figures 
Table 29. Diesel Engines Manufactured by Truck Type Diesel Engines Manufactured for Heavy Trucks

\begin{tabular}{|c|c|c|c|c|c|}
\hline \multicolumn{6}{|c|}{ Diesel Engines Manufactured for Heavy Trucks } \\
\hline & 2005 & 2006 & 2007 & 2008 & 2009 \\
\hline Cummins & 89,642 & 102,645 & 78,435 & 91,754 & 63,584 \\
\hline Navistar & 34,342 & 41,942 & 26,804 & 31,160 & 24,716 \\
\hline Detroit Diesel & 61,076 & 63,812 & 29,506 & 35,174 & 24,616 \\
\hline Mack & 36,221 & 36,198 & 18,544 & 16,794 & 10,376 \\
\hline Mercedes Benz & 37,670 & 40,148 & 31,101 & 18,647 & 6,613 \\
\hline Caterpillar & 116,732 & 131,659 & 44,246 & 25,184 & 5,428 \\
\hline Volvo & 19,298 & 23,455 & 9,850 & 8,822 & 4,116 \\
\hline PACCAR & 0 & 0 & 9,072 & 5,333 & 2,661 \\
\hline Hino & 814 & 1,497 & 1,319 & 730 & 745 \\
\hline GM & 0 & 0 & 0 & 0 & 0 \\
\hline Grand Total & 395,795 & 441,356 & 248,877 & 233,598 & 142,855 \\
\hline \multicolumn{6}{|c|}{ Diesel Engines Manufactured for Medium Trucks } \\
\hline & 2005 & 2006 & 2007 & 2008 & 2009 \\
\hline Navistar & 159,927 & 138,910 & 120,724 & 78,922 & 66,939 \\
\hline Cummins & 4,620 & 5,072 & 7,408 & 11,217 & 6,542 \\
\hline Hino & 4,187 & 5,992 & 4,911 & 2,332 & 1,965 \\
\hline GM & 19,244 & 18,086 & 13,544 & 13,118 & 1,872 \\
\hline Mercedes Benz & 6,782 & 11,591 & 5,277 & 1,344 & 431 \\
\hline PACCAR & 0 & 0 & 0 & 381 & 184 \\
\hline Caterpillar & 12,424 & 10,954 & 3,679 & 1,184 & 83 \\
\hline Detroit Diesel & 957 & 5 & 0 & 0 & 0 \\
\hline Mack & 0 & 0 & 0 & 0 & 0 \\
\hline Volvo & 0 & 0 & 0 & 0 & 0 \\
\hline Grand Total & 208,141 & 190,610 & 155,543 & 108,498 & 78,016 \\
\hline \multicolumn{6}{|c|}{ Diesel Engines Manufactured for Medium and Heavy Trucks } \\
\hline & 2005 & 2006 & 2007 & 2008 & 2009 \\
\hline Cummins & 249,569 & 241,555 & 199,159 & 170,676 & 130,523 \\
\hline Detroit Diesel & 38,962 & 47,014 & 34,212 & 42,377 & 31,258 \\
\hline Caterpillar & 65,263 & 69,804 & 34,417 & 37,506 & 26,581 \\
\hline Mack & 55,465 & 54,284 & 32,088 & 29,912 & 12,248 \\
\hline Mercedes Benz & 44,452 & 51,739 & 36,378 & 19,991 & 7,044 \\
\hline Volvo & 116,732 & 131,659 & 44,246 & 25,565 & 5,612 \\
\hline Navistar & 31,722 & 34,409 & 13,529 & 10,006 & 4,199 \\
\hline Hino & 957 & 5 & 9,072 & 5,333 & 2,661 \\
\hline GM & 814 & 1,497 & 1,319 & 730 & 745 \\
\hline PACCAR & 0 & 0 & 0 & 0 & 0 \\
\hline Grand Total & 603,936 & 631,966 & 404,420 & 342,096 & 220,871 \\
\hline
\end{tabular}

Note: These data include only factory sales of diesel trucks.

Source: Ward's Motor Vehicle Facts and Figures

\section{Energy intensity is affected by different players during manufacturing and operation}

The fuel consumption of medium and heavy trucks is affected by a variety of players during the manufacturing process and operation. As the preceding sections indicated, heavy- and medium-truck vehicle manufacturers are not always the same as the engine manufacturers for those vehicles. Rather, the established process by which medium and heavy trucks are manufactured involves multiple companies, each with their own manufacturing techniques. Table 31 follows the flow of the manufacturing process, from engine design and manufacturing through body and trailer design, to operation. The factors affecting fuel economy and the companies (or vehicle operator) that control the relevant design parameters are listed under each stage.

\section{Heavy-truck emissions have been reduced drastically in recent years}

Medium- and heavy-truck emissions have declined significantly to meet new standards imposed by the EPA. Manufacturers hold information on nitrogen oxide and PM emissions proprietary and confidential. However, because no manufacturer has failed to meet the requirements during the past five years, it is apparent that all trucks have at least met-and potentially exceeded-these regulations. In 2002, PM was regulated at 0.1 grams per horsepower-hour (g/HP-hr, a unit that describes the grams of the pollutant as a result of the use of the energy equivalent of 1 horsepower for one hour); $\mathrm{NO}_{\mathrm{x}}$ was regulated at $2.5 \mathrm{~g} / \mathrm{HP}-\mathrm{hr}$. In 2007, these regulations were 
Table 30. Available Models of Hybrid and Electric Cargo Trucks

\begin{tabular}{|c|c|c|c|c|}
\hline Truck OEM/Chassis & Model & Body Type/Application & Fuel & GVW Class \\
\hline Bright Automotive & IDEA & Cargo Van & Gasoline hybrid & 1 \\
\hline Ford & $\mathrm{E} 450$ & Step Van, Shuttle Bus & Gasoline hybrid & 3 \\
\hline GMC & TC5500 & Utility & Gasoline hybrid & 5 \\
\hline Freightliner & $\begin{array}{l}\text { Business Class M2e } \\
\text { Hybrid }\end{array}$ & City Delivery, Utility, Delivery Tractor & Diesel hybrid & 7,8 \\
\hline Freightliner CCC & MT-45, MT-55 & Walk-in Van & Diesel hybrid & \\
\hline Kenworth & $\mathrm{T} 270$ & Delivery, Utility & Diesel hybrid & 6 \\
\hline Kenworth & T370 & Delivery, Utility & Diesel hybrid & 7 \\
\hline Mack/Volvo & TerraPro Hybrid & Refuse & Diesel hybrid & 8 \\
\hline Navistar, Inc & $\begin{array}{l}\text { DuraStar Hybrid } \\
\text { (Truck) }\end{array}$ & $\begin{array}{l}\text { Beverage, Box Van, Refrigeration, Landscape Dump, Utility, } \\
\text { Crane, Tree Trimmer, Recovery Towing, Armored Vehicle, } \\
\text { Stake Flat, Grapple, Road Patch Truck, Refined Fuels, Propane } \\
\text { Tank }\end{array}$ & Diesel hybrid & 6,7 \\
\hline Navistar, Inc & 4300 & Utility, Digger Derrick, Air Compressor & Diesel hybrid & $6,7,8$ \\
\hline Navistar, Inc & $\begin{array}{l}\text { DuraStar Hybrid ( } 4 \times 2) \\
\text { Tractor }\end{array}$ & Beverage Diminishing Load & Diesel hybrid & 7 \\
\hline Navistar, Inc & $\begin{array}{l}\text { WorkStar Hybrid } \\
\text { (Truck) }\end{array}$ & $\begin{array}{l}\text { 4x4 Utility, Landscape Dump, Snowplow, Digger Derrick, } \\
\text { Utility, Crane, Stake Flat, Box Van, Recovery Towing, Refined } \\
\text { Fuels, Propane Tank }\end{array}$ & Diesel hybrid & 6,7 \\
\hline Peterbilt & $\begin{array}{l}320 \text { Hybrid (Hydraulic } \\
\text { Launch Assist) }\end{array}$ & Refuse & Diesel hybrid & 8 \\
\hline Peterbilt & 330 Hybrid & Delivery van & Diesel hybrid & 6 \\
\hline Peterbilt & 337 Hybrid & $\begin{array}{l}\text { City Delivery, Fire \& Rescue, Beverage, Municipal, Refuse, } \\
\text { Utility }\end{array}$ & Diesel hybrid & 6,7 \\
\hline Peterbilt & 348 Hybrid & Municipal, Service, Utility & Diesel hybrid & 7,8 \\
\hline Peterbilt & 386 Hybrid & Long Haul & Diesel hybrid & 8 \\
\hline Ford & Transit Connect & Cargo Van & Full electric & 1 \\
\hline Modec & $\begin{array}{l}\text { Chassis Cab, Dropside \& } \\
\text { Box Van }\end{array}$ & $\begin{array}{l}\text { Chassis Cab, Dropside, Box Van, Refrigerated Box Van, Tail Lift, } \\
\text { Tipper }\end{array}$ & Full electric & 3 \\
\hline Navistar, Inc & eStar & Delivery Van & Full electric & 3 \\
\hline $\begin{array}{l}\text { Smith Electric } \\
\text { Vehicles }\end{array}$ & Newton & $\begin{array}{l}\text { Food Distribution, Parcel Delivery, Chilled Food Distribution, } \\
\text { Short Haul, Utility, Airport Operations, Public Sector }\end{array}$ & Full electric & $5,6,7$ \\
\hline
\end{tabular}

Source: Environmental Defense Fund, Innovation Exchange.

made much more stringent: $\mathrm{NO}_{\mathrm{x}}$ emissions were cut in half (to $1.2 \mathrm{~g} / \mathrm{HP}-\mathrm{hr}$ ) and PM emissions were cut by $90 \%$ (to $0.01 \mathrm{~g} / \mathrm{HP}-\mathrm{hr}$ ). $\mathrm{NO}_{\mathrm{x}}$ emissions were cut another $83 \%$ to 0.2 g/HP-hr in 2010 (Figure 26). In response, the emissions by medium and heavy trucks were successfully cut accordingly. The sales of heavy trucks are shown in Figure 27 - the years in which new diesel emission regulations took place are noted by the darker bars.
Figure 26. Diesel Emission Regulations

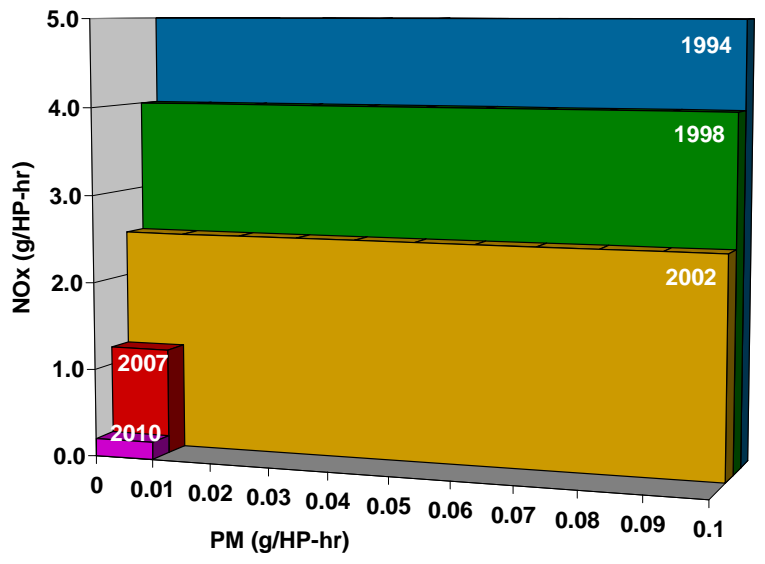

Source: EPA 
Table 31. Factors Affecting Fuel Economy

\begin{tabular}{|c|c|c|c|c|c|}
\hline & Engine Manufacturer & Chassis Manufacturer & $\begin{array}{c}\text { Body } \\
\text { Manufacturer }\end{array}$ & Trailer Manufacturer & Owner/Operator \\
\hline Single Unit Trucks & -Engine design & $\begin{array}{l}\text {-Drive train design } \\
\text {-Vehicle accessories } \\
\text {-Cab acrodynamics } \\
\text {-Chassis rolling resistance }\end{array}$ & $\begin{array}{l}\text {-Body } \\
\text { aerodynamics } \\
\text {-Vocational loads }\end{array}$ & & $\begin{array}{l}\text {-Vehicle speed } \\
\text {-Driver behavior }\end{array}$ \\
\hline $\begin{array}{l}\text { Combination } \\
\text { Trucks }\end{array}$ & •Engine design & $\begin{array}{l}\text {-Drive train design } \\
\text {-Vehicle accessories } \\
\text {-Cab aerodynamics } \\
\text {-Chassis rolling resistance }\end{array}$ & & $\begin{array}{l}\text {-Trailer aerodynamics } \\
\text { - Trailer aerodynamics }\end{array}$ & $\begin{array}{l}\text {-Truck-trailer pairing } \\
\text {-Vehicle speed } \\
\text {-Driver hehavior }\end{array}$ \\
\hline Manufacturers & $\begin{array}{l}\text { Navistar } \\
\text { Cummins } \\
\text { GM } \\
\text { Detroit Diesel } \\
\text { Catcrpillar } \\
\text { Mercedes-Benz. } \\
\text { Mack } \\
\text { Volvo } \\
\text { PACCAR }\end{array}$ & $\begin{array}{l}\text { Daimler Trucks North } \\
\quad \text { America (Freightliner, } \\
\quad \text { Western Star) } \\
\text { International } \\
\text { Peterbilt } \\
\text { Kenworth } \\
\text { Ford } \\
\text { Volvo Truck } \\
\text { Mack } \\
\text { GM } \\
\text { Hino }\end{array}$ & & $\begin{array}{l}\text { Wahash National } \\
\text { Great Dane } \\
\text { Utility Trailer } \\
\text { Hyundai Translead } \\
\text { Stoughton Trailers } \\
\text { Vanguard National Trailer } \\
\text { MANAC } \\
\text { Trailmobile Canada } \\
\text { Heil Trailer International } \\
\text { Strick } \\
\text { (many others) }\end{array}$ & \\
\hline
\end{tabular}

Source: DieselNet

When the 2002 regulations were enacted, engine and truck manufacturers responded by implementing exhaust gas recirculation (several companies) or advanced combustion emissions reduction technology (CAT). The 2007 regulations required the addition of a diesel particulate filter for all companies. Table 32 shows the timeline of these technologies; Table 33 shows their means of operation and efficacies.

Figure 27. Heavy Truck Sales in Relation to Diesel Emission Regulations

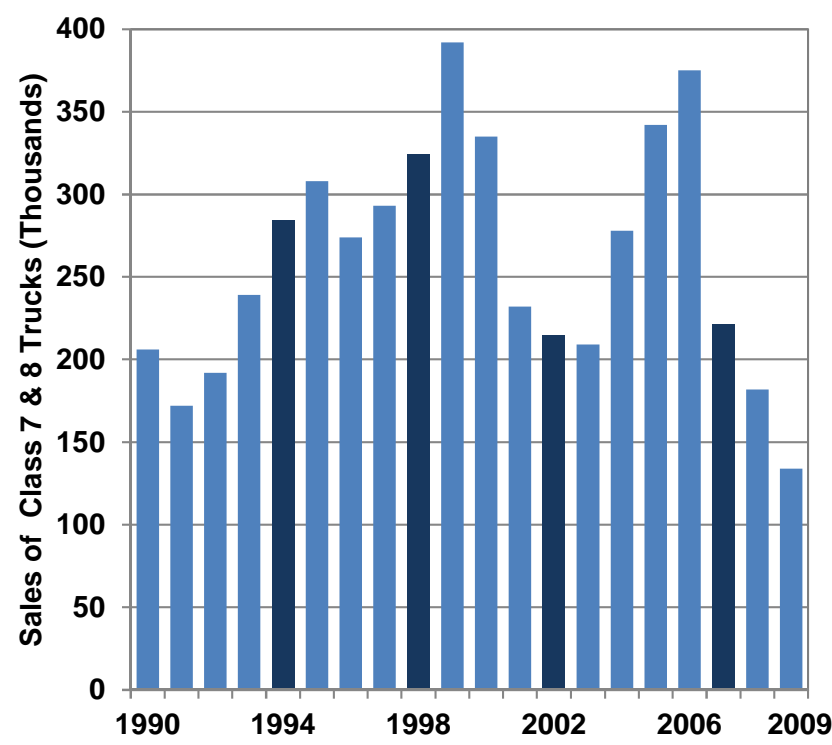

Note: Dark bars indicate years in which new diesel emission regulations are enacted.

Source: Ward's Facts and Figures, EPA

\section{Medium and heavy trucks are more likely to be diesel vehicles}

Most class 4-8 trucks operate on diesel fuel. Traditionally, diesel has been a less expensive fuel, so the vehicle's lifetime cost of ownership was less than that of a comparable gasoline vehicle. Recently, however, diesel prices have increased and been consistently higher than gasoline prices. The diesel price spikes in late 2007 and early 2008 caused a minor shift away from diesel heavy trucks (Figure 28 and Table 34). Surprisingly, diesels plummeted to $35.7 \%$ of class 7 sales in 2009 from a high of $58.5 \%$ in 2006.

\section{Figure 28. Diesel Truck Sales Shares by Class}

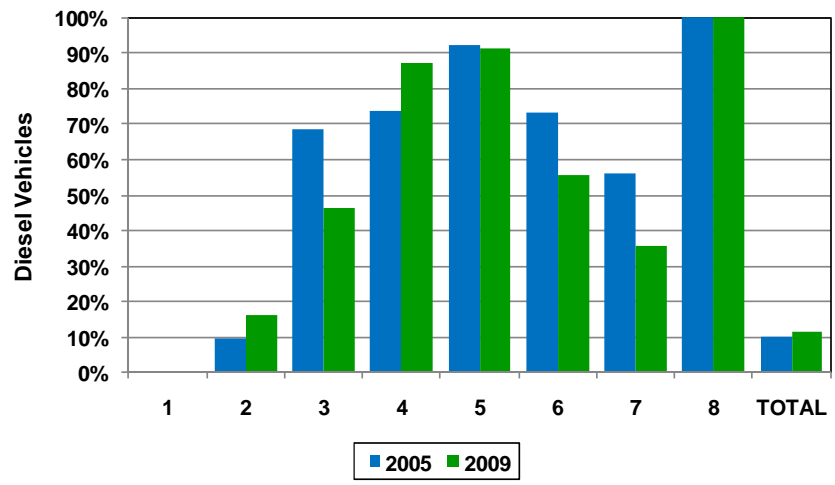

Source: Ward's Motor Vehicle Facts and Figures

This shift was relatively small, because diesel fuel prices returned to levels similar to that of gasoline in 2009. Another explanation for the continued reliance on vehicles powered by diesel engines is the efficiency and performance of diesel engines: They offer higher low-end torque and they can be considered more durable and longer-lasting. 
Table 32. Emission Control Technologies

\begin{tabular}{|c|c|c|c|c|c|c|}
\hline & 2004 & 2005 & 2006 & 2007 & 2008 & 2009 \\
\hline Caterpillar & $\begin{array}{l}\text { advanced } \\
\text { combustion } \\
\text { emissions } \\
\text { reduction } \\
\text { technology }\end{array}$ & $\begin{array}{l}\text { advanced } \\
\text { combustion } \\
\text { emissions } \\
\text { reduction } \\
\text { technology }\end{array}$ & $\begin{array}{l}\text { advanced } \\
\text { combustion } \\
\text { emissions } \\
\text { reduction } \\
\text { technology }\end{array}$ & $\begin{array}{c}\text { diesel } \\
\text { particulate filter } \\
\text { \& clean gas } \\
\text { induction }\end{array}$ & $\begin{array}{c}\text { diesel } \\
\text { particulate filter } \\
\text { \& clean gas } \\
\text { induction }\end{array}$ & $\begin{array}{c}\text { diesel } \\
\text { particulate filter } \\
\text { \& clean gas } \\
\text { induction }\end{array}$ \\
\hline Cummins & $\begin{array}{l}\text { exhaust gas } \\
\text { recirculation }\end{array}$ & $\begin{array}{l}\text { exhaust gas } \\
\text { recirculation }\end{array}$ & $\begin{array}{l}\text { exhaust gas } \\
\text { recirculation }\end{array}$ & $\begin{array}{l}\text { diesel } \\
\text { particulate filter } \\
\text { \& exhaust gas } \\
\text { recirculation }\end{array}$ & $\begin{array}{c}\text { diesel } \\
\text { particulate filter } \\
\text { \& exhaust gas } \\
\text { recirculation }\end{array}$ & $\begin{array}{l}\text { diesel } \\
\text { particulate filter } \\
\text { \& exhaust gas } \\
\text { recirculation }\end{array}$ \\
\hline Detroit Diesel & $\begin{array}{l}\text { exhaust gas } \\
\text { recirculation }\end{array}$ & $\begin{array}{l}\text { exhaust gas } \\
\text { recirculation }\end{array}$ & $\begin{array}{l}\text { exhaust gas } \\
\text { recirculation }\end{array}$ & $\begin{array}{c}\text { diesel } \\
\text { particulate filter } \\
\text { \& exhaust gas } \\
\text { recirculation }\end{array}$ & $\begin{array}{c}\text { diesel } \\
\text { particulate filter } \\
\text { \& exhaust gas } \\
\text { recirculation }\end{array}$ & $\begin{array}{l}\text { diesel } \\
\text { particulate filter } \\
\text { \& exhaust gas } \\
\text { recirculation }\end{array}$ \\
\hline Navistar & $\begin{array}{l}\text { exhaust gas } \\
\text { recirculation }\end{array}$ & $\begin{array}{l}\text { exhaust gas } \\
\text { recirculation }\end{array}$ & $\begin{array}{l}\text { exhaust gas } \\
\text { recirculation }\end{array}$ & $\begin{array}{l}\text { diesel } \\
\text { particulate filter } \\
\text { \& exhaust gas } \\
\text { recirculation }\end{array}$ & $\begin{array}{l}\text { diesel } \\
\text { particulate filter } \\
\text { \& exhaust gas } \\
\text { recirculation }\end{array}$ & $\begin{array}{l}\text { diesel } \\
\text { particulate filter } \\
\text { \& exhaust gas } \\
\text { recirculation }\end{array}$ \\
\hline Mack/Volvo & $\begin{array}{l}\text { exhaust gas } \\
\text { recirculation }\end{array}$ & $\begin{array}{l}\text { exhaust gas } \\
\text { recirculation }\end{array}$ & $\begin{array}{l}\text { exhaust gas } \\
\text { recirculation }\end{array}$ & $\begin{array}{c}\text { diesel } \\
\text { particulate filter } \\
\text { \& exhaust gas } \\
\text { recirculation }\end{array}$ & $\begin{array}{c}\text { diesel } \\
\text { particulate filter } \\
\text { \& exhaust gas } \\
\text { recirculation }\end{array}$ & $\begin{array}{c}\text { diesel } \\
\text { particulate filter } \\
\text { \& exhaust gas } \\
\text { recirculation }\end{array}$ \\
\hline
\end{tabular}

Source: $21^{\text {st }}$ Century Truck Partnership Interviews and DieselNet

Table 33. Emission Control Technologies Explained

\begin{tabular}{|c|c|c|c|c|}
\hline \multicolumn{5}{|c|}{ Emission Control Technologies } \\
\hline $\begin{array}{l}\text { Emission Control } \\
\text { Device }\end{array}$ & Description & $\begin{array}{l}\text { Expected NOx } \\
\text { Efficiency }\end{array}$ & $\begin{array}{l}\text { Expected PM } \\
\text { Efficiency }\end{array}$ & Status \\
\hline $\begin{array}{l}\text { Exhaust Gas } \\
\text { Recirculation }\end{array}$ & $\begin{array}{l}\text { Recycles the exhaust gas } \\
\text { back to the engine intake } \\
\text { system }\end{array}$ & $50 \%-60 \%$ & $\mathrm{n} / \mathrm{a}$ & $\begin{array}{l}\text { In commercial use; still concerns about } \\
\text { condensation, packaging and engine } \\
\text { integration constraints such as fuel and } \\
\text { air management system upgrades. }\end{array}$ \\
\hline $\begin{array}{l}\text { Advanced Combustion } \\
\text { Emissions Reduction } \\
\text { Technology }\end{array}$ & $\begin{array}{l}\text { Controls ratio of air and fuel } \\
\text { to minimize emissions. }\end{array}$ & & & In commercial use. \\
\hline $\begin{array}{l}\text { Diesel Particulate } \\
\text { Filter }\end{array}$ & $\begin{array}{l}\text { Collects particles in diesel } \\
\text { exhaust }\end{array}$ & $\mathrm{n} / \mathrm{a}$ & $80 \%-90 \%$ & In commercial use. \\
\hline Clean Gas Induction & $\begin{array}{l}\text { Draws clean inert gas from } \\
\text { downstream of the } \\
\text { particulate filter and inserts } \\
\text { into the intake air system. }\end{array}$ & & & In commercial use. \\
\hline $\begin{array}{l}\text { Selective Catalytic } \\
\text { Reduction (SCR) }\end{array}$ & $\begin{array}{l}\text { Converts NOx to nitrogen } \\
\text { and oxygen in the presence } \\
\text { of urea }\end{array}$ & $70 \%-90 \%$ & $20 \%-30 \%$ & $\begin{array}{l}\text { Used in marine and stationary engines; } \\
\text { first commercial application in heavy } \\
\text { duty engines underway. }\end{array}$ \\
\hline
\end{tabular}

Source: $21^{\text {st }}$ Century Truck Partnership Interviews and DieselNet 


\section{Truck stop electrification reduces idle fuel consumption}

The U.S. Department of Transportation mandates that truckers rest for 10 hours after driving for 11 hours, during which time, truck operators often park at truck stops. Often they idle their engines during this rest time to provide their sleeper compartments with air conditioning or heating, or to run electrical appliances such as refrigerators or televisions. Electrification at truck stops allows truckers to "plug in" vehicles to operate necessary systems without idling the engine. Truck stop electrification can reduce diesel emissions and save trucking companies the cost of fuel that would be used while idling. The U.S. EPA estimates that fuel savings can be as high as $\$ 3,240$ per parking space. Additionally, truck stop electrification can allow truckers to accommodate local idling regulations and reduce noise.

In "single system electrification," a system owned and operated by a truck stop provides heating, ventilation, and air conditioning (HVAC) systems from a power module contained in a structure above the parking spaces. A hose from the HVAC system is connected to the truck window, and a computer touch screen enables payment. These stand-alone systems are owned and maintained by private companies that charge an hourly fee. To accommodate the HVAC hose, a window template must be installed in the truck. IdleAire Inc. at one time operated single-system electrified parking spaces at 131 sites spread over 34 states, half of which were concentrated in six states. Over 150,000 professional drivers and more than 100 fleets were actively using IdleAire services, according to their website. IdleAire filed for Chapter 11 bankruptcy in 2008 and began restarting service in May 2010.

"Shore power systems" provide electrical outlets that trucks can plug into. To use these systems, the truck must be equipped with an inverter to convert 120-volt power, an electrical HVAC system, and the hardware to plug into the electrical outlet. Truck stop outlets are owned by private companies that regulate use and fees; onboard equipment is owned and maintained by the trucking company. Industry experts estimate that there are 60,000 class 8 trucks with sleepers that are shore power capable, and $50 \%$ of all new class 8 trucks have 120VAC connections for block heaters, oil pan heaters, fuel-water separators, and battery chargers. Shorepower Technologies is the largest provider of these systems; they operate eight locations in Oregon and Washington.

More than 130 truck stops nationwide are equipped with idle reduction facilities, half of which are concentrated in six states (Table 35).
Table 34. Diesel Truck Sales as a Percent of Total Truck Sales

\begin{tabular}{|c|r|r|r|r|r|}
\hline Class & $\mathbf{2 0 0 5}$ & $\mathbf{2 0 0 6}$ & $\mathbf{2 0 0 7}$ & $\mathbf{2 0 0 8}$ & $\mathbf{2 0 0 9}$ \\
\hline $\mathbf{1}$ & $0.1 \%$ & $0.0 \%$ & $0.0 \%$ & $0.0 \%$ & $0.0 \%$ \\
\hline $\mathbf{2}$ & $9.5 \%$ & $10.1 \%$ & $10.4 \%$ & $12.9 \%$ & $16.1 \%$ \\
\hline $\mathbf{3}$ & $68.6 \%$ & $68.6 \%$ & $42.5 \%$ & $44.1 \%$ & $46.5 \%$ \\
\hline $\mathbf{4}$ & $73.8 \%$ & $75.7 \%$ & $78.3 \%$ & $80.9 \%$ & $87.2 \%$ \\
\hline $\mathbf{5}$ & $92.2 \%$ & $91.6 \%$ & $91.8 \%$ & $92.3 \%$ & $91.3 \%$ \\
\hline $\mathbf{6}$ & $73.4 \%$ & $75.3 \%$ & $52.4 \%$ & $58.0 \%$ & $55.6 \%$ \\
\hline $\mathbf{7}$ & $55.8 \%$ & $58.5 \%$ & $50.4 \%$ & $50.3 \%$ & $35.7 \%$ \\
\hline $\mathbf{8}$ & $100.0 \%$ & $100.0 \%$ & $99.9 \%$ & $99.7 \%$ & $99.9 \%$ \\
\hline TOTAL & $10.3 \%$ & $11.6 \%$ & $9.3 \%$ & $10.8 \%$ & $11.7 \%$ \\
\hline
\end{tabular}

Source: Ward's Motor Vehicle Facts and Figures

\section{Table 35. Truck Stop Electrification Sites}

\begin{tabular}{|c|c|c|c|c|}
\hline State & 2006 & 2007 & 2008 & 2009 \\
\hline TX & 12 & 19 & 22 & 21 \\
\hline CA & 10 & 13 & 13 & 13 \\
\hline $\mathrm{OH}$ & - & 10 & 11 & 11 \\
\hline PA & 3 & 9 & 11 & 11 \\
\hline IL & - & 7 & 7 & 7 \\
\hline AR & 2 & 6 & 6 & 6 \\
\hline Other & 19 & 66 & 66 & 69 \\
\hline Total & 46 & 130 & 136 & 138 \\
\hline
\end{tabular}

Because truck stop electrification infrastructure is still expanding, the codes and standards that ensure uniformity and interoperability for trucks are critical. Recently, the Society of Automotive Engineers Committee, in conjunction with the Electric Power Research Institute, established the J2698 standard for the 120V AC electrification of trucks. Since then, the Technology \& Maintenance Council Task Force on the establishment of Recommended Practice (RP) 437 has published "Guidelines for Truck Stop Electrification Interface."

\section{Heavy trucks are increasingly comprised of advanced materials}

Aluminum and high-strength steel vs. conventional steel; super-wide tires vs. conventional (dual) tires; and extensive use of "plastics" are common throughout American trucking (Table 36). In general, advanced materials penetrate the market as a function of the price.

American heavy-truck hoods are made from lightweight and cost-effective plastic. More advanced materials have been less successful in penetrating the market. For example, long carbon fiber (LCF) hoods are not widely used due to the overwhelming costs to compete with widely used sheet molded compound. LCF and similar truck cab and hood "plastic" materials were proven cost-prohibitive by DOE. Interestingly, one of the LCF cost factors presented during that study was the prices paid for huge wind turbine blades, comprised of 
LCF, that convert wind power into electricity. At present, LCF was and remains beyond the bounds of private industry to justify.

Table 36. Heavy Truck Materials

\begin{tabular}{|c|c|}
\hline Conventional Material & Advanced Material \\
\hline - conventional steel & $\begin{array}{l}\text { - high-strength steel } \\
\text { - aluminum } \\
\text { - plastics }\end{array}$ \\
\hline - conventional dual tires & - super-wide tires \\
\hline
\end{tabular}

Source: $21^{\text {st }}$ Century Truck Partnership Interviews

\section{Energy performance was relatively steady}

The average fuel economy for medium- and heavyduty trucks increased slightly from 2004 to 2008. These fuel economy figures are only rough estimates. Mediumand heavy-truck companies consider fuel economy data confidential and proprietary, so the average fuel economies presented here are derived from related data in the Federal Highway Administration's Highway Statistics. More accurate truck fuel economy data were estimated in the past as part of the Vehicle Inventory and Use Survey, which was conducted every five years by the Bureau of the Census-the survey was discontinued in 2002.

Fuel economies for combination units (separate tractor and trailer) are less than those of single-units (tractor and trailer on a single chassis) because combination units tend to be box-like trailers, which are designed to maximize freight capacity over aerodynamics (Table 37). Because fuel economies vary significantly among truck types, payloads carried, and duty cycles, it is not considered to be the best metric for truck efficiency. The variation of fuel consumption by truck configuration and vocation is demonstrated in the proposed EPA/NHTSA CO2 fuel consumption regulations for 2017, which are shown in this report in Figures 40 and 41 on page 44 . Because these regulations refer to the future, Table 37 is still instructive as an indicator of medium and heavy trucks energy consumption today.

Table 37. Medium and Heavy Truck Fuel Economy (mpg)

\begin{tabular}{|c|c|c|c|c|c|c|}
\hline Calendar Year & $\mathbf{2 0 0 4}$ & $\mathbf{2 0 0 5}$ & $\mathbf{2 0 0 6}$ & $\mathbf{2 0 0 7}$ & $\mathbf{2 0 0 8}$ & $\mathbf{5 - y r} \boldsymbol{~}$ \\
\hline Single-Unit & 8.8 & 8.3 & 8.2 & 8.2 & 8.5 & $-3 \%$ \\
\hline Combination & 5.9 & 5.2 & 5.1 & 5.1 & 5.4 & $-8 \%$ \\
\hline $\begin{array}{l}\text { Single-Unit \& } \\
\text { Combination }\end{array}$ & 6.7 & 6.0 & 5.9 & 5.9 & 6.2 & $-7 \%$ \\
\hline
\end{tabular}

Source: FHWA, Highway Statistics

\section{Measuring medium and heavy truck energy intensity requires a freight- based metric}

In a comparison of three "average" vehicles' fuel economies, a half-ton pickup can achieve $22 \mathrm{mpg}$, a medium truck achieves only $6.5 \mathrm{mpg}$, and a tractor hauling a triple trailer - a heavy truck-achieves only $3.5 \mathrm{mpg}$. A freight-based metric more appropriately reflects the energy intensity of the medium and heavy trucks. The medium truck, with a potential cargo volume of 4,000 cubic feet, could achieve a volume-based energy intensity ( $\mathrm{ft}^{3}$-mi/gal) of eight times that of the light truck; and the heavy truck, with a cargo volume of 11,000 cubic $\mathrm{ft}$, could achieve 24 times that of the light truck. Similarly, the medium truck, with a gross vehicle weight of 30 tons, could achieve a volume-based energy intensity ( $\left.\mathrm{ft}^{3}-\mathrm{mi} / \mathrm{gal}\right)$ of eight times that of the light truck; and the heavy truck, with a cargo volume of 11,000 cubic ft, could achieve 12 times that of the light truck.

The National Academy of Sciences (NAS) has reviewed the appropriate metric to use for regulating truck fuel economy. They explored many different metrics, including miles per gallon, gallons per mile, gallons per ton-mile, and gallons per $\mathrm{ft}^{3}$-mile. Some experts prefer fuel consumption metrics to fuel economy metrics because they express fuel consumption linearly-fuel economy metrics do not. For example, a 5-mpg increase in fuel economy from $10 \mathrm{mpg}$ to $15 \mathrm{mpg}$ saves more fuel than a 5 mpg increase from $15 \mathrm{mpg}$ to $20 \mathrm{mpg}$. The advisory principles resulting from the study were:

- The metric should incentivize subcomponent and total vehicle development;

- The metric should relate to the transport task or vehicle vocation;

- The metric should encourage energy conservation for a given task; and

- The metric should be based on energy or fuel consumption - e.g. equivalent diesel gallons/cargo ton-mile, normalizing to equivalent diesel fuel to take into account the differing energy densities of fuels.

Regulations on medium and heavy truck fuel economy and greenhouse gas emissions were proposed in 2010 and are based on gallons per ton-mile (and CO2 per ton-mile) as the Academy recommended. Additional details on the proposed standards are in a following section of the report. 


\section{Corporate average fuel economy rules require more fuel-efficient vehicles}

CAFE rules-the sales-weighted harmonic mean fuel economy of a manufacturer's fleet of current model year cars or light trucks with a GVWR of 8,500 pounds or lesshas increased slightly during the past five years. The requirement for cars has been constant at $27.5 \mathrm{mpg}$ during this period, while the requirement for light trucks has increased from $20.7 \mathrm{mpg}$ in 2004 to 23.9 in 2009 (an increase of 10\%) (Figure 29). Beginning in MY 2008, manufacturers have an additional choice of CAFE standards. Light trucks can be held to a reformed standard which accounts for the size of the vehicle. The calculation uses the vehicle footprint (the distance between the wheels multiplied by the distance between the axles), and each manufacturer can choose to use this reformed standard or the unreformed standard for MY 2008 through MY 2011. The reformed standard for 2009 is $23.4 \mathrm{mpg}$.

\section{Figure 29. CAFE Standards for Cars and Light Trucks}

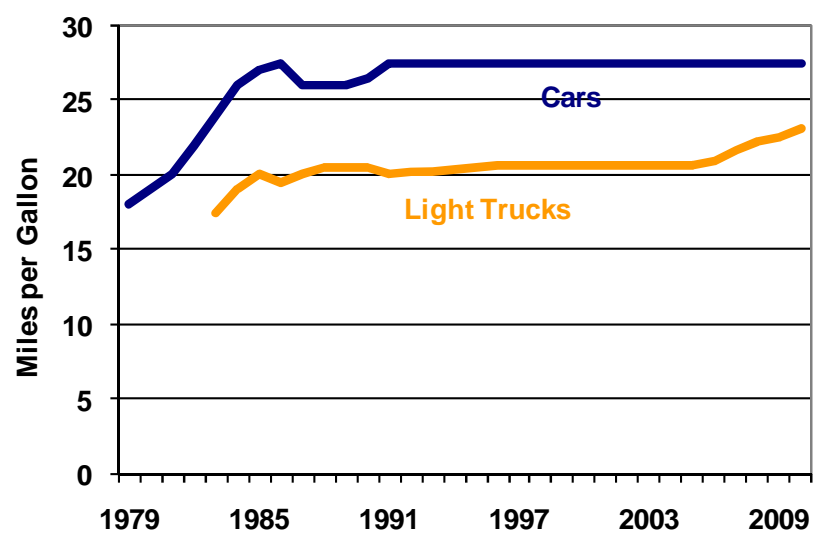

Source: NHTSA, Summary of Fuel Economy Performance

\section{The Alternative Motor Fuels Act eases CAFE requirements for flex- fuel fleets}

The Alternative Motor Fuels Act (AMFA) of 1988 enabled OEMs to increase their calculated CAFE by producing FFVs. The act, extended by the Automotive Fuel Economy Manufacturing Incentives for Alternative Fueled Vehicles Rule of 2004, encourages the production of motor vehicles capable of operating on alternative fuels. It gives a credit of up to $1.2 \mathrm{mpg}$ toward an automobile manufacturer's CAFE, which helps it avoid penalties of the CAFE standards.
Ford and General Motors have taken nearly full advantage of the credit for the past five years: Their credits for light truck CAFE have been at or near the $1.2 \mathrm{mpg}$ limit allowed by law (Table 38). Credits for cars have historically tended to be less for all manufacturers-until recently, when several manufacturers received the maximum credit.

Table 38. AMFA Flex Fuel CAFE Credits

\begin{tabular}{|l|c|c|c|c|c|c|}
\hline & 2004 & 2005 & 2006 & 2007 & 2008 \\
\hline CHR & 0.0 & 0.1 & 0.1 & 1.0 & 1.5 \\
\hline FMC & 1.3 & 1.1 & 0.8 & 1.5 & 1.2 \\
\hline GMC & 1.2 & 1.0 & 1.1 & 2.7 & 2.0 \\
\hline NIS & 0.0 & 0.8 & 0.9 & 1.1 & 1.4 \\
\hline & \multicolumn{5}{|c|}{ Light Trucks } \\
\hline CHR & 0.6 & 0.3 & 0.2 & 0.2 & 0.9 \\
\hline FMC & 0.6 & 1.0 & 1.0 & 0.9 & 1.3 \\
\hline GMC & 0.0 & 0.0 & 1.6 & 1.6 & 2.1 \\
\hline NIS & 0.0 & 0.0 & 0.0 & 0.0 & 0.0 \\
\hline & \multicolumn{5}{|c|}{ Import Cars } \\
\hline CHR & 0.5 & 0.6 & 0.0 & 1.9 & 2.0 \\
\hline
\end{tabular}

Note: The maximum credit is $1.2 \mathrm{mpg}$; where the calculated credit exceeds the maximum credit, the maximum credit applies. Data on 2009 and 2010 credits for these manufacturers are not available.

Source: NHTSA Flexible Fuel Credits 2003-2010

\section{Light vehicle emissions standards require clean diesels}

Light-vehicle diesel engines and gasoline engines must meet the same emissions regulations. The EPA allows certification at eight alternative levels (or "bins"), as long as a manufacturer's sales-weighted average is lower than or equal to Bin 5 levels. Table 39 shows the eight alternative bins (Bin 1 through Bin 8), as well as the two that were used prior to 2006. Until 2006, EPA had allowed certification to Bin 9 and Bin 10, which were specially designed to allow diesels into the marketplace, because they allowed PM emission levels of $0.08 / 0.06 \mathrm{~g} / \mathrm{mi}$, respectively; and $\mathrm{NO}_{\mathrm{x}}$ emission levels of $0.60 / 0.30 \mathrm{~g} / \mathrm{mi}$, respectively. These bins were phased out at the end of 2006, and all other bins required PM emission standards of $0.02 \mathrm{~g} / \mathrm{mi}$ or lower. These essentially mandate the use of PM traps and low-sulfur diesel fuel. 
Table 39. Diesel Emission Standards

\begin{tabular}{|c|c|c|c|c|}
\hline \multicolumn{5}{|c|}{ Emission Standards $(\mathbf{g} / \mathbf{m i})$} \\
\hline BIN & NOx & NMOG & CO & PM \\
\hline $\mathbf{1 0}$ & 0.60 & 0.156 & 4.2 & 0.08 \\
\hline $\mathbf{9}$ & 0.30 & 0.090 & 4.2 & 0.06 \\
\hline $\mathbf{8}$ & 0.20 & 0.125 & 4.2 & 0.02 \\
\hline $\mathbf{7}$ & 0.15 & 0.090 & 4.2 & 0.02 \\
\hline $\mathbf{6}$ & 0.10 & 0.090 & 4.2 & 0.01 \\
\hline $\mathbf{5}$ & 0.07 & 0.090 & 4.2 & 0.01 \\
\hline $\mathbf{4}$ & 0.04 & 0.070 & 2.1 & 0.01 \\
\hline $\mathbf{3}$ & 0.03 & 0.055 & 2.1 & 0.01 \\
\hline $\mathbf{2}$ & 0.02 & 0.010 & 2.1 & 0.01 \\
\hline $\mathbf{1}$ & 0.00 & 0.000 & 0.0 & 0.00 \\
\hline
\end{tabular}

Source: EEA

${ }^{1}$ References to EEA refer to a 2008 Light-Duty Diesel Report by Energy and Environmental Analysis (EEA), an ICF International Company, funded by DOE.

California has more restrictive emission standards offering a choice of levels approximately equal to bins 1,2 and 5 of the federal levels. Even stricter standards may be required for 2015 .

Of the top 100 global suppliers in 2009, six were emission control suppliers (Table 40). Eaton Corp., which was not on the list in 2005, has $70 \%$ of their sales in the United States. Other companies, such as Faurenci and Benteler Automobilietechnik have increased their share of U.S. sales slightly over the five-year period.

\section{Ultralow sulfur diesel (ULSD) requirements sparked the re- emergence of light diesel vehicles}

The ULSD standard has increased the availability of diesel-fueled cars in the United States. Without ULSD fuel, new diesel vehicles would not be able to meet the strict EPA emission standards. Sulfur levels in ULSD are comparable to European grades, so European engines no longer need to be redesigned to cope with higher sulfur content and may now use advanced emissions-control systems that would otherwise be damaged by sulfur.

The EPA proposed ULSD fuel as a new standard for the sulfur content in on-road diesel fuel sold in the United States, which has been in effect since October 15, 2006. The EPA mandated the use of ULSD fuel in model year 2007 as well as the newer highway diesel fuel engines equipped with advanced emission-control systems that require that fuel. The allowable sulfur content for ULSD (15 ppm) is much lower than the previous U.S. on-highway standard for low-sulfur diesel (LSD, 500 ppm), which allows use of advanced emission-control systems that would otherwise be poisoned by sulfur.

California has required ULSD since September 1, 2006, and rural Alaska will transition all diesel fuel to ULSD in 2010. By December 1, 2010, all U.S. highway diesel fuel will be ULSD.

\section{High fuel economy diesel vehicles are subsidized}

The Federal Alternative Fuel Vehicle Tax Credit provision of the Energy Policy Act of 2005 (EPAct 2005) includes a tax credit for lean-burn diesel vehicles. The credit, sometimes referred to as the Clean Diesel Tax Credit, became effective January 1, 2006. Light-diesel vehicles receive a subsidy in the form of a tax credit

Table 40. Leading Suppliers in Emissions Control

\begin{tabular}{|c|c|c|c|c|c|}
\hline \multicolumn{6}{|c|}{ Leading Suppliers in Emissions Control } \\
\hline \multicolumn{3}{|c|}{2005} & \multicolumn{3}{|l|}{2009} \\
\hline Company & $\begin{array}{c}\text { Total U.S. } \\
\text { Sales (Mil\$) }\end{array}$ & $\begin{array}{c}\text { U.S. \% of } \\
\text { Global Sales }\end{array}$ & Company & $\begin{array}{c}\text { Total U.S. } \\
\text { Sales (Mil\$) }\end{array}$ & $\begin{array}{c}\text { U.S. \% of } \\
\text { Global } \\
\text { Sales }\end{array}$ \\
\hline Magneti Marelli Holding S.p.A. & $27,000.0$ & $(6 \%)$ & Benteler Automobiltechnik GmbH & $1,902.4$ & $(29 \%)$ \\
\hline ArvinMeritor Inc. & $4,498.7$ & $(51 \%)$ & Faurecia & $1,560.0$ & $(12 \%)$ \\
\hline Faurenci & $1,540.0$ & $(11 \%)$ & Tenneco Inc. & $1,553.6$ & $(43 \%)$ \\
\hline Tenneco, Inc. & $1,504.8$ & $(44 \%)$ & CalsonicKansei Corp. & $1,055.7$ & $(17 \%)$ \\
\hline CalsonicKansei Corp. & $1,419.9$ & $(22 \%)$ & Eaton Corp. & 860.3 & $(70 \%)$ \\
\hline Benteler Automobiltechnik GmbH & $1,269.0$ & $(27 \%)$ & Magneti Marelli S.p.A. & 236.6 & $(4 \%)$ \\
\hline Kolbenschmidt Pierburg AG & 360.0 & $(15 \%)$ & & & \\
\hline J. Eberspaecher GmbH & 234.0 & $(13 \%)$ & & & \\
\hline
\end{tabular}


proportional to the fuel economy increase over a comparable MY 2002 vehicle. The tax credit can be as large as $\$ 2,400$ for a vehicle whose fuel economy is at least 2.5 times higher than the reference 2002 vehicle fuel economy.

Diesel vehicles up to 6,000 pounds gross vehicle weight rating (GVWR) that meet EPA Tier II Bin 5 emissions requirements will be eligible for the credit. Diesel vehicles of 6,001 to 8,500 GVWR must meet Tier II Bin 8 requirements. No 2006, 2007, or 2008 diesel vehicles met the emissions requirements for credit; however, four vehicles in MY 2009 and seven vehicles in MY 2010 are eligible (Table 41).

\section{Diesels enjoy economies of scale in Europe}

According to EEA, high diesel sales enable economies of scale, because every ten-fold increase in production cuts the cost by approximately 30\% to 35\%. Typical production levels for U.S. manufacturers planning to enter the diesel market are likely to be at 100,000 vehicles per year per engine model while European producers typically produce at four to eight times that level. From 2006 to 2008, more than $50 \%$ of new cars sold in Europe have been diesels (Figure 30). In 2009, the diesel penetration rate decreased to $46 \%$, overall, likely due to sharp changes in the gasoline vs. diesel prices in Europe and the enactment of vehicle scrappage programs in several European countries.

Table 41. Federal Diesel Vehicle Credits

\begin{tabular}{|c|c|c|c|c|}
\hline \multirow{2}{*}{ Vehicle Make \& Model } & \multirow{2}{*}{$\begin{array}{c}\text { Full } \\
\text { Credit }\end{array}$} & \multicolumn{2}{|c|}{ Phase Out } & \multirow{2}{*}{ No Credit } \\
\hline & & $50 \%$ & $25 \%$ & \\
\hline Audi & $\begin{array}{l}\text { Jan. 1, } \\
2006\end{array}$ & $\begin{array}{c}\text { July } 1 \text { - Dec. 31, } \\
2010\end{array}$ & N/A & $\begin{array}{l}\text { Jan. 1, } \\
2011\end{array}$ \\
\hline 2010 Audi A3 2.0L TDI & $\$ 1,300$ & $\$ 650$ & -- & $\$ 0$ \\
\hline 2009-10 Audi Q7 3.0L TDI & $\$ 1,150$ & $\$ 575$ & -- & $\$ 0$ \\
\hline BMW & $\begin{array}{l}\text { Jan. 1, } \\
2006\end{array}$ & TBD & N/A & $\begin{array}{c}\text { Jan. 1, } \\
2011\end{array}$ \\
\hline 2009-11 BMW 335d Sedan & $\$ 900$ & -- & -- & $\$ 0$ \\
\hline 2009-11 BMW X5 xDrive35d & $\$ 1,800$ & -- & -- & $\$ 0$ \\
\hline Mercdes-Benz & $\begin{array}{l}\text { Jan. 1, } \\
2006\end{array}$ & TBD & N/A & $\begin{array}{l}\text { Jan. 1, } \\
2011\end{array}$ \\
\hline 2010 Mercedes-Benz GL 350 BlueTEC & $\$ 1,800$ & -- & -- & $\$ 0$ \\
\hline 2010 Mercedes-Benz ML 350 BlueTEC & $\$ 900$ & $\overline{--}$ & $\overline{--}$ & $\$ 0$ \\
\hline 2010 Mercedes-Benz R 350 BlueTEC & $\$ 1,550$ & -- & -- & $\$ 0$ \\
\hline 2009 Mercedes-Benz GL 320 BlueTEC & $\$ 1,800$ & $\overline{--}$ & $\overline{--}$ & $\$ 0$ \\
\hline 2009 Mercedes-Benz ML 320 BlueTEC & $\$ 900$ & -- & -- & $\$ 0$ \\
\hline 2009 Mercedes-Benz R 320 BlueTEC & $\$ 1,550$ & $\overline{--}$ & $\overline{--}$ & $\$ 0$ \\
\hline Volkswagen & $\begin{array}{l}\text { Jan. 1, } \\
2006\end{array}$ & $\begin{array}{c}\text { July } 1 \text { - Dec. 31, } \\
2010\end{array}$ & N/A & $\begin{array}{c}\text { Jan. 1, } \\
2011\end{array}$ \\
\hline 2010 Volkswagen Golf 2.0L TDI (automatic) & $\$ 1,700$ & $\$ 850$ & -- & $\$ 0$ \\
\hline 2010 Volkswagen Golf 2.0L TDI (manual) & $\$ 1,300$ & $\$ 650$ & $\overline{--}$ & $\$ 0$ \\
\hline 2009-10 Volkswagen Jetta 2.0L TDI Sedan & $\$ 1,300$ & $\$ 650$ & -- & $\$ 0$ \\
\hline 2009-10 Volkswagen Jetta 2.0L TDI SportWagon & $\$ 1,300$ & $\$ 650$ & $\overline{--}$ & $\$ 0$ \\
\hline 2009-10 Volkswagen Touareg 3.0L TDI & $\$ 1,150$ & $\$ 575$ & -- & $\$ 0$ \\
\hline
\end{tabular}

Source: DOE/EPA, Fueleconomy.Gov 
Figure 30. Diesel Share of New Car Sales in Europe.

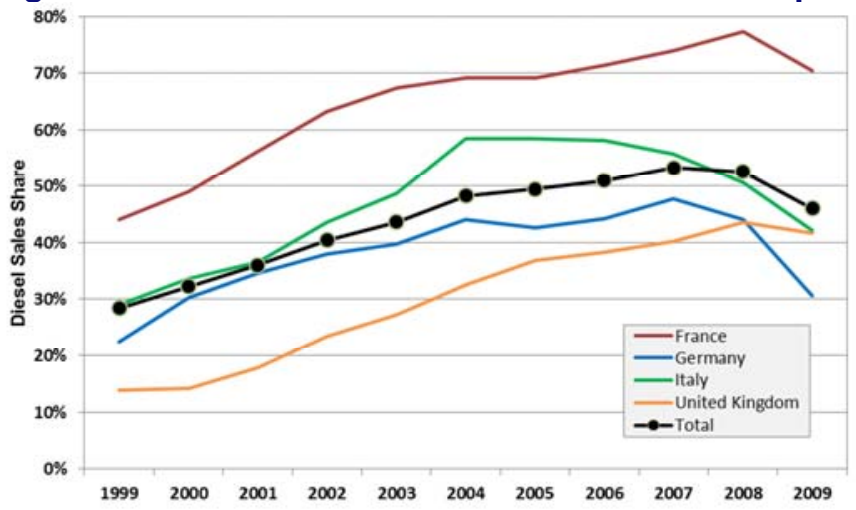

Source: AID Newsletters

\section{Special tax credits incentivize the purchase of HEVs}

Hybrids bought or placed into service after December 31,2005 , may be eligible for a federal income tax credit of up to $\$ 3,400$ (Table 42). The Internal Revenue Service must first acknowledge the manufacturers' certifications of qualified vehicles and credit amounts, which are based on improved fuel economy and lifetime fuel-savings potential.

Credit amounts begin to phase out for a given manufacturer once it has sold more than 60,000 eligible vehicles. The subsidy decreases by half at the second calendar quarter after the manufacturers' sales reach that mark, The subsidy is halved again at the beginning of the fourth quarter after the sales reach the 60,000 -vehicle mark. The credit ends at the beginning of the sixth calendar quarter. In addition to the phase-out rules, any vehicle bought after December 31, 2010, will not be eligible for the credit.

Four states also have tax credits, and the state of Washington and the District of Columbia have tax exemptions that give consumers a financial incentive to purchase HEVs (Table 43). Other states give incentives such as allowing HEVs in high-occupancy vehicle lanes, designating special parking spaces, exempting HEVs from emission inspections, and discounting insurance or registration fees. Several states also give tax credits, tax exemptions, or grants to businesses that manufacture or develop hybrid parts and technology.

\section{Federal subsidies discount alternative fuels}

An excise tax credit is available for certain alternative fuels that are sold for use or used as a fuel to operate a motor vehicle. The credit is $\$ 0.50$ per gasoline gallon equivalent of compressed natural gas (CNG) and $\$ 0.50$ per liquid gallon of liquefied petroleum gas (LPG), liquefied natural gas (LNG), P-Series fuel, liquid fuel derived from coal through the Fischer-Tropsch process, and compressed or liquefied gas derived from biomass and liquefied hydrogen. The entity eligible for the credit is the one liable for reporting and paying the federal excise tax on the fuel. Eligible entities must be registered with the Internal Revenue Service.

An alternative fuel blender is eligible for a $\$ 0.50$ per gallon excise tax credit when producing an alternative fuel blend containing at least $0.1 \%$ gasoline, diesel, or kerosene. Qualified fuels are CNG, LNG, LPG, P-Series fuel, liquid fuel derived from coal through the Fischer-Tropsch process, and compressed or liquefied gas derived from biomass. A $\$ 0.50$ excise tax credit is also available for the sale or use of liquefied hydrogen used to produce a mixture containing a taxable fuel.

Biodiesel users that deliver pure, unblended biodiesel (B100) into the tank of a vehicle or use B100 as an on-road fuel in their trade or business may be eligible for a nonrefundable income tax credit in the amount of $\$ 1$ per gallon of agri-biodiesel, such as biodiesel made from soybean oil. If the biodiesel was sold at retail, only the person that sold the fuel and placed it into the tank of the vehicle is eligible for the tax credit. The volumetric excise tax does not apply to the sale or use of B100.

For ethanol, blenders registered with the Internal Revenue Service are eligible for the Volumetric Ethanol Excise Tax Credit VEETC, an excise tax credit in the amount of $\$ 0.45$ per gallon of pure ethanol (minimum 190 proof) blended with gasoline. Only entities that have produced and sold or used the qualified ethanol mixture as a fuel in their trade or business are eligible for the credit. This tax credit expires on December 31, 2011. There is also a blender credit for biodiesel, separate from the user credit. An entity that blends B100 with diesel to produce a mixture containing at least $0.1 \%$ diesel fuel may be eligible for a nonrefundable income tax credit in the amount of $\$ 1$ per gallon of agri-biodiesel (e.g., biodiesel made from soybean oil), or pure biodiesel made from other sources (e.g., waste grease). Only blenders that have produced, sold, or used the qualified biodiesel mixture as a fuel in their trade or business are eligible for the tax credit.

Biofuels are the only advanced fuels not derived from a fossil fuel. However, unlike the petroleum industry, the biofuels industry is not dominated by just a few players. There are many companies at a similar technical level, and DOE has worked with a number of them, in addition to the biofuels industry associations (the National Biodiesel Board and Renewable Fuels Association). 
Table 42. Federal HEV Credits

\begin{tabular}{|c|c|c|c|c|c|}
\hline \multirow{2}{*}{\multicolumn{2}{|c|}{ Vehicle Make \& Model }} & \multirow{3}{*}{$\begin{array}{c}\text { Full } \\
\text { Credit } \\
\text { Jan. 1, } \\
2006 \\
\end{array}$} & \multicolumn{2}{|c|}{ Phase Out } & \multirow{2}{*}{ No Credit } \\
\hline & & & $50 \%$ & $25 \%$ & \\
\hline \multicolumn{2}{|l|}{ BMW } & & TBD & TBD & TBD \\
\hline 2011 BMW ActiveHybrid 750i & & $\$ 900$ & -- & -- & -- \\
\hline 2011 BMW ActiveHybrid 750Li & & $\$ 900$ & -- & -- & -- \\
\hline 2010 BMW ActiveHybrid X6 & & $\$ 1,550$ & -- & -- & -- \\
\hline \multicolumn{2}{|l|}{ Chrysler } & $\begin{array}{l}\text { Jan. 1, } \\
2006\end{array}$ & TBD & TBD & TBD \\
\hline 2009 Chrysler Aspen Hybrid & & $\$ 2,200$ & -- & -- & -- \\
\hline 2009 Dodge Durango Hybrid & & $\$ 2,200$ & -- & -- & -- \\
\hline \multicolumn{2}{|l|}{ Ford Motor Company } & $\begin{array}{l}\text { Jan. 1, } \\
2006\end{array}$ & $\begin{array}{l}\text { Apr. 1 - Sep. } \\
\text { 30, } 2009\end{array}$ & $\begin{array}{c}\text { Oct. 1, } \\
\text { 2009 - } \\
\text { Mar. 31, } \\
2010\end{array}$ & $\begin{array}{l}\text { Apr. 1, } \\
2010\end{array}$ \\
\hline \multirow{2}{*}{2010 Ford Escape Hybrid } & $2 W D$ & $\$ 3,000$ & $\$ 1,500$ & $\$ 750$ & $\$ 0$ \\
\hline & $4 \mathrm{WD}$ & $\$ 2,600$ & $\$ 1,300$ & $\$ 650$ & $\$ 0$ \\
\hline 2010 Ford Fusion Hybrid & & $\$ 3,400$ & $\$ 1,700$ & $\$ 850$ & $\$ 0$ \\
\hline \multirow{2}{*}{2010 Mercury Mariner Hybrid } & $2 W D$ & $\$ 3,000$ & $\$ 1,500$ & $\$ 750$ & $\$ 0$ \\
\hline & $4 \mathrm{WD}$ & $\$ 2,600$ & $\$ 1,300$ & $\$ 650$ & $\$ 0$ \\
\hline \multirow{2}{*}{2009 Ford Escape Hybrid } & $2 W D$ & $\$ 3,000$ & $\$ 1,500$ & $\$ 750$ & $\$ 0$ \\
\hline & $4 \mathrm{WD}$ & $\$ 1,950$ & $\$ 975$ & $\$ 487.50$ & $\$ 0$ \\
\hline \multirow{2}{*}{2009 Mercury Mariner Hybrid } & $2 \mathrm{WD}$ & $\$ 3,000$ & $\$ 1,500$ & $\$ 750$ & $\$ 0$ \\
\hline & $4 \mathrm{WD}$ & $\$ 1,950$ & $\$ 975$ & $\$ 487.50$ & $\$ 0$ \\
\hline \multirow{2}{*}{2008 Ford Escape Hybrid } & $2 W D$ & $\$ 3,000$ & $\$ 1,500$ & $\$ 750$ & $\$ 0$ \\
\hline & $4 \mathrm{WD}$ & $\$ 2,200$ & $\$ 1,100$ & $\$ 550$ & $\$ 0$ \\
\hline \multirow{2}{*}{2008 Mercury Mariner Hybrid } & $2 \mathrm{WD}$ & $\$ 3,000$ & $\$ 1,500$ & $\$ 750$ & $\$ 0$ \\
\hline & $4 \mathrm{WD}$ & $\$ 2,200$ & $\$ 1,100$ & $\$ 550$ & $\$ 0$ \\
\hline \multirow{2}{*}{ 2006-07 Ford Escape Hybrid } & $2 W D$ & $\$ 2,600$ & $\$ 1,300$ & $\$ 650$ & $\$ 0$ \\
\hline & $4 \mathrm{WD}$ & $\$ 1,950$ & $\$ 975$ & $\$ 487.50$ & $\$ 0$ \\
\hline 2006-07 Mercury Mariner Hybric & 4WD & $\$ 1,950$ & $\$ 975$ & $\$ 487.50$ & $\$ 0$ \\
\hline \multirow{2}{*}{2005 Ford Escape Hybrid } & $2 W D$ & $\$ 2,600$ & $\$ 1,300$ & $\$ 650$ & $\$ 0$ \\
\hline & 4WD & $\$ 1,950$ & $\$ 975$ & $\$ 488$ & $\$ 0$ \\
\hline \multicolumn{6}{|c|}{ Ford hybrids purchased after March 31,2010 , are not eligible for this tax credit. } \\
\hline \multicolumn{2}{|l|}{ General Motors } & $\begin{array}{l}\text { Jan. 1, } \\
2006\end{array}$ & TBD & TBD & TBD \\
\hline \multicolumn{2}{|c|}{2010 Cadillac Escalade Hybrid (2WD \& 4WD) } & $\$ 2,200$ & -- & -- & -- \\
\hline \multicolumn{2}{|l|}{2010 Chevrolet Malibu Hybrid } & $\$ 1,550$ & -- & -- & -- \\
\hline \multicolumn{2}{|c|}{2010 Chevrolet Silverado Hybrid (2WD \& 4WD) } & $\$ 2,200$ & -- & -- & -- \\
\hline \multicolumn{2}{|c|}{2010 Chevrolet Tahoe Hybrid (2WD \& 4WD) } & $\$ 2,200$ & -- & -- & -- \\
\hline \multicolumn{2}{|c|}{2010 GMC Sierra Hybrid (2WD \& 4WD) } & $\$ 2,200$ & -- & -- & -- \\
\hline \multicolumn{2}{|c|}{2010 GMC Yukon 1500 Hybrid (2WD \& 4WD) } & $\$ 2,200$ & -- & -- & -- \\
\hline \multicolumn{2}{|c|}{2010 GMC Yukon Denali 1400 Hybrid (2WD \& 4WD) } & $\$ 2,200$ & -- & -- & -- \\
\hline \multirow{2}{*}{2009 Cadillac Escalade Hybrid } & $2 W D$ & $\$ 2,200$ & -- & -- & -- \\
\hline & 4WD & $\$ 1,800$ & -- & -- & -- \\
\hline \multicolumn{2}{|l|}{2009 Chevrolet Malibu Hybrid } & $\$ 1,550$ & -- & -- & -- \\
\hline
\end{tabular}

Continued on next page. 
Table 42. Federal HEV Credits (continued)

\begin{tabular}{|c|c|c|c|c|c|}
\hline \multicolumn{2}{|c|}{2009 Chevrolet Silverado Hybrid (2WD \& 4WD) } & $\$ 2,200$ & -- & -- & -- \\
\hline \multicolumn{2}{|c|}{2009 Chevrolet Tahoe Hybrid (2WD \& 4WD) } & $\$ 2,200$ & -- & -- & -- \\
\hline \multicolumn{2}{|c|}{2009 GMC Sierra Hybrid (2WD \& 4WD) } & $\$ 2,200$ & -- & -- & -- \\
\hline \multicolumn{2}{|c|}{2009 GMC Yukon 1500 Hybrid (2WD \& 4WD) } & $\$ 2,200$ & -- & -- & -- \\
\hline \multicolumn{2}{|l|}{2009 Saturn Aura Hybrid } & $\$ 1,550$ & -- & -- & -- \\
\hline \multicolumn{2}{|l|}{2009 Saturn Aura Hybrid } & $\$ 1,550$ & -- & -- & -- \\
\hline \multicolumn{2}{|l|}{2008 Chevrolet Malibu Hybrid } & $\$ 1,300$ & -- & -- & -- \\
\hline \multicolumn{2}{|c|}{2008 Chevrolet Tahoe Hybrid (2WD \& 4WD) } & $\$ 2,200$ & -- & -- & -- \\
\hline \multicolumn{2}{|c|}{2008 GMC Yukon 1500 Hybrid (2WD \& 4WD) } & $\$ 2,200$ & -- & -- & -- \\
\hline \multicolumn{2}{|l|}{2008 Saturn Aura Hybrid } & $\$ 1,300$ & -- & -- & -- \\
\hline \multicolumn{2}{|l|}{2008 Saturn Vue Hybrid } & $\$ 1,550$ & -- & -- & -- \\
\hline \multirow{2}{*}{2007 Chevrolet Silverado Hybrid } & 2WD & $\$ 250$ & -- & -- & -- \\
\hline & 4WD & $\$ 650$ & -- & -- & -- \\
\hline \multirow{2}{*}{2007 GMC Sierra Hybrid } & 2WD & $\$ 250$ & -- & -- & -- \\
\hline & 4WD & $\$ 650$ & -- & -- & -- \\
\hline \multicolumn{2}{|l|}{2007 Saturn Aura Hybrid } & $\$ 1,300$ & -- & -- & -- \\
\hline \multicolumn{2}{|l|}{2007 Saturn Vue Hybrid } & $\$ 650$ & -- & -- & -- \\
\hline \multirow{2}{*}{2006 Chevrolet Silverado Hybrid } & 2WD & $\$ 250$ & -- & -- & -- \\
\hline & 4WD & $\$ 650$ & -- & -- & -- \\
\hline \multirow{2}{*}{2006 GMC Sierra Hybrid } & $2 \mathrm{WD}$ & $\$ 250$ & -- & -- & -- \\
\hline & 4WD & $\$ 650$ & -- & -- & -- \\
\hline \multicolumn{2}{|l|}{ Honda } & $\begin{array}{c}\text { Jan. 1, } \\
2006 \text { - Dec. } \\
\text { 31, } 2007\end{array}$ & $\begin{array}{l}\text { Jan. 1- Jun. 30, } \\
2008\end{array}$ & $\begin{array}{c}\text { July 1- Dec. } \\
31,2008\end{array}$ & $\begin{array}{c}\text { Jan. 1, } \\
2009\end{array}$ \\
\hline \multicolumn{2}{|l|}{2008 Civic Hybrid CVT } & $\$ 2,100$ & $\$ 1,050$ & $\$ 525$ & $\$ 0$ \\
\hline \multicolumn{2}{|l|}{2007 Accord Hybrid AT \& Navi AT } & $\$ 1,300$ & $\$ 650$ & $\$ 325$ & $\$ 0$ \\
\hline \multicolumn{2}{|l|}{2007 Civic Hybrid CVT } & $\$ 2,100$ & $\$ 1,050$ & $\$ 525$ & $\$ 0$ \\
\hline \multicolumn{2}{|l|}{2006 Insight CVT } & $\$ 1,450$ & $\$ 724$ & $\$ 362.50$ & $\$ 0$ \\
\hline \multicolumn{2}{|l|}{2006 Accord Hybrid AT \& Navi AT } & $\$ 650$ & $\$ 325$ & $\$ 162.50$ & $\$ 0$ \\
\hline \multicolumn{2}{|l|}{2006 Accord Hybrid AT \& Navi AT } & $\$ 1,300$ & $\$ 650$ & $\$ 325$ & $\$ 0$ \\
\hline \multicolumn{2}{|l|}{2006 Civic Hybrid CVT } & $\$ 2,100$ & $\$ 1,050$ & $\$ 525$ & $\$ 0$ \\
\hline \multicolumn{2}{|l|}{2005 Insight CVT } & $\$ 1,450$ & $\$ 725$ & $\$ 362.50$ & $\$ 0$ \\
\hline \multicolumn{2}{|l|}{2005 Accord Hybrid AT \& Navi AT } & $\$ 650$ & $\$ 325$ & $\$ 162.50$ & $\$ 0$ \\
\hline 2005 Civic Hybrid (SULEV) MT \& & & $\$ 1,700$ & $\$ 850$ & $\$ 425$ & $\$ 0$ \\
\hline Honda hybrids purchased aft & cembc & 31,2008, & e not eligible f & $r$ this tax cr & \\
\hline Mazda & & $\begin{array}{c}\text { Jan. 1, } \\
2006\end{array}$ & TBD & TBD & TBD \\
\hline 2000 Manda Tributo Unbuid & 2WD & $\$ 3,000$ & -- & -- & -- \\
\hline 2009 lvazaa irioute Hyoria & 4WD & $\$ 1,950$ & -- & -- & -- \\
\hline 2000 Manda Tributo Unbrid & 2WD & $\$ 3,000$ & -- & -- & -- \\
\hline 2008 ivazda iriouce fyorid & 4WD & $\$ 2,200$ & -- & -- & -- \\
\hline
\end{tabular}

Continued on next page 
Table 42. Federal HEV Credits (continued)

\begin{tabular}{|c|c|c|c|c|}
\hline Mercdes-Benz & $\begin{array}{l}\text { Jan. 1, } \\
2006\end{array}$ & TBD & TBD & TBD \\
\hline 2010 Mercedes-Benz ML 450 Hybrid & $\$ 2,200$ & -- & -- & -- \\
\hline 2010 Mercedes-Benz S400 Hybrid & $\$ 1,150$ & -- & -- & -- \\
\hline Nissan & $\begin{array}{l}\text { Jan. 1, } \\
2006\end{array}$ & TBD & TBD & TBD \\
\hline 2007-10 Altima Hybrid & $\$ 2,350$ & -- & -- & -- \\
\hline Toyota & $\begin{array}{c}\text { Jan. } 1 \text { - } \\
\text { Sep. 30, } \\
2006\end{array}$ & $\begin{array}{l}\text { Oct. 1, } 2006 \text { - } \\
\text { Mar. 31, } 2007\end{array}$ & $\begin{array}{c}\text { Apr. 1 - } \\
\text { Sep. 30, } \\
2007\end{array}$ & $\begin{array}{l}\text { Oct. 1, } \\
2007\end{array}$ \\
\hline 2008 Prius & $\$ 3,150$ & $\$ 1,575$ & $\$ 787.50$ & $\$ 0$ \\
\hline 2008 Highlander Hybrid (2WD \& 4WD) & $\$ 2,600$ & $\$ 1,300$ & $\$ 650$ & $\$ 0$ \\
\hline 2008 Lexus RX400h (2WD \& 4WD) & $\$ 2,200$ & $\$ 1,100$ & $\$ 550$ & $\$ 0$ \\
\hline 2008 Camry Hybrid & $\$ 2,600$ & $\$ 1,300$ & $\$ 650$ & $\$ 0$ \\
\hline 2008 Lexus LS 600h & -- & -- & $\$ 450$ & $\$ 0$ \\
\hline 2007 Prius & $\$ 3,150$ & $\$ 1,575$ & $\$ 787.50$ & $\$ 0$ \\
\hline 2007 Highlander Hybrid (2WD \& 4WD) & $\$ 2,600$ & $\$ 1,300$ & $\$ 650$ & $\$ 0$ \\
\hline 2007 Lexus RX400h (2WD \& 4WD) & $\$ 2,200$ & $\$ 1,100$ & $\$ 550$ & $\$ 0$ \\
\hline 2007 Camry Hybrid & $\$ 2,600$ & $\$ 1,300$ & $\$ 650$ & $\$ 0$ \\
\hline 2007 Lexus GS 450h & $\$ 1,550$ & $\$ 775$ & $\$ 387.5$ & $\$ 0$ \\
\hline 2006 Prius & $\$ 3,150$ & $\$ 1,575$ & $\$ 787.5$ & $\$ 0$ \\
\hline 2006 Highlander Hybrid (2WD \& 4WD) & $\$ 2,600$ & $\$ 1,300$ & $\$ 650$ & $\$ 0$ \\
\hline 2006 Lexus RX400h (2WD \& 4WD) & $\$ 2,200$ & $\$ 1,100$ & $\$ 550$ & $\$ 0$ \\
\hline 2005 Prius & $\$ 3,150$ & $\$ 1,575$ & 787.5 & $\$ 0$ \\
\hline
\end{tabular}

Source: DOE/EPA, Fueleconomv.Gov

Table 43. State HEV Tax Credits and Exemptions

\begin{tabular}{|l|l|}
\hline \multicolumn{1}{|c|}{$\begin{array}{l}\text { HEV Tax Credit } \\
\text { Colorado }\end{array}$} & $\begin{array}{l}\text { Income tax credits vary, with a maximum of } \$ 6,000.00 \\
\text { Income tax credit of } 50 \% \text { of the incremental purchase cost. }\end{array}$ \\
\hline Oklahoma & $\begin{array}{l}\text { Tax credit of } 10 \% \text { of the total vehicle cost, up to } \$ 1,500, \text { if the } \\
\text { incremental cost of new AFV cannot be when AFV is resold, as } \\
\text { long a tax credit was not previously taken on the vehicle. }\end{array}$ \\
\hline Oregon & $\begin{array}{l}\text { Residential tax credit up to } \$ 1,500 ; \text { Business tax credit of up to } \\
35 \% \text { of incremental purchase cost }\end{array}$ \\
\hline South Carolina & Income tax credit of $20 \%$ of the Federal tax credit. \\
\hline Dashington & HehV Tax Exemption \\
\hline Dehicle excise tax exemption
\end{tabular}

Source: Alternative Fuels and Advanced Vehicles Data Center 


\section{Consumers still face limited alternative fuel availability}

From 2005 to 2009, the total number of alternative fuel stations increased by 24\%-from 5,164 in 2005 to 6,411 in 2009. Ethanol and biodiesel are the two fuels that have gained the most in the five-year period (Figures 3135). There were 1,928 E85 stations in 2009; only five years earlier, there were only 177. Similarly, the number of biodiesel stations had grown to 679 in 2009 from only 208 in 2005. Despite significant growth in the number of stations, biofuel availability pales in comparison to conventional gasoline. According to the U.S. National Petroleum News, as of 2008, there were 161,786 retail gasoline outlets in the United States, thus, about $1 \%$ of stations offering gasoline also offer E85. In contrast, the numbers of LPG stations have decreased. There were about 500 fewer LPG stations in 2009 than in 2005.

Figure 31. Number of Alternative Fuel Stations

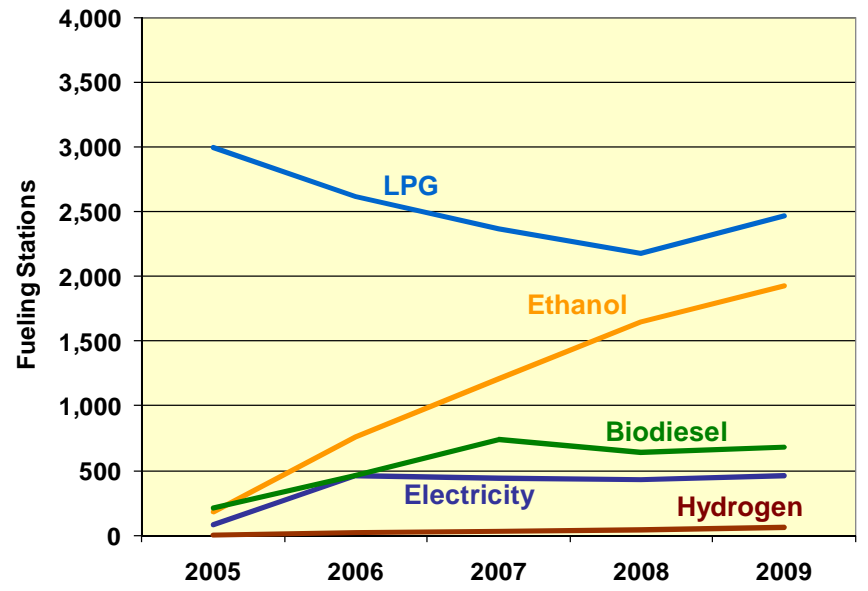

Source: Alternative Fuels and Advanced Vehicles Data Center

Figure 32. Map of E-85 Stations

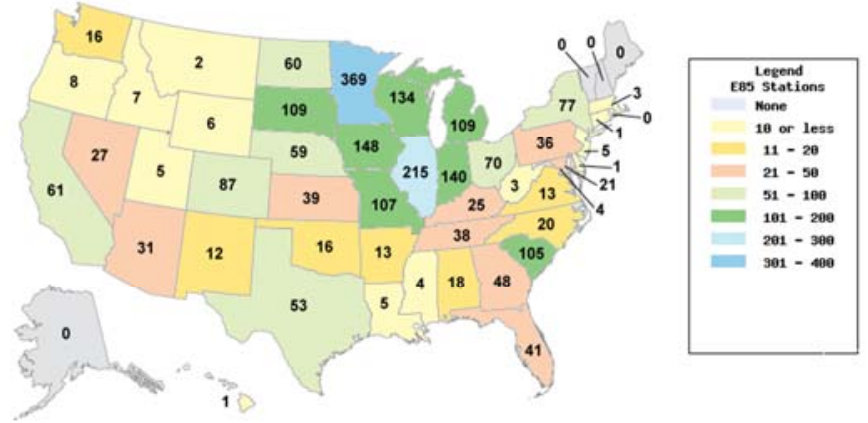

Source: U.S. Department of Energy, Alternative Fuels Data Center
Figure 33. Map of Biodiesel Stations

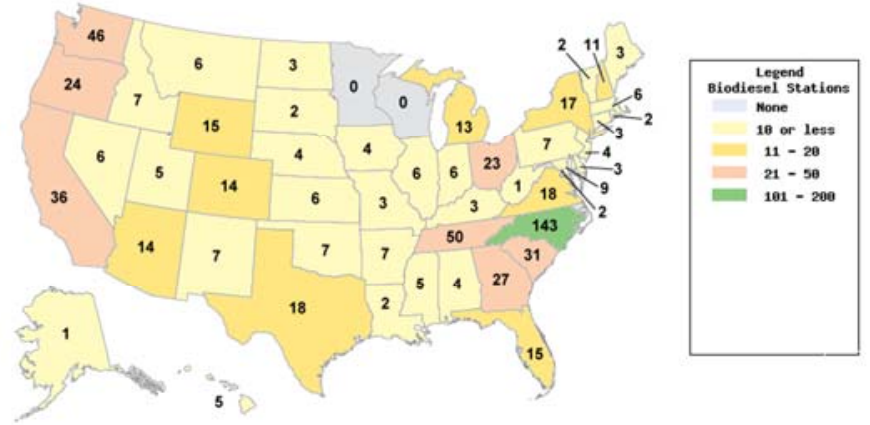

Source: U.S. Department of Energy, Alternative Fuels Data Center

Figure 34. Map of Electric Vehicle Charging Stations

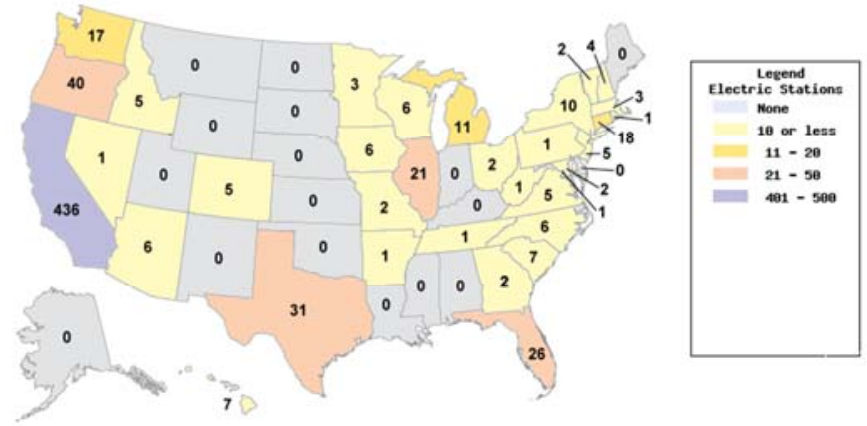

Source: U.S. Department of Energy, Alternative Fuels Data Center

Figure 35. Map of Hydrogen Vehicle Charging Stations

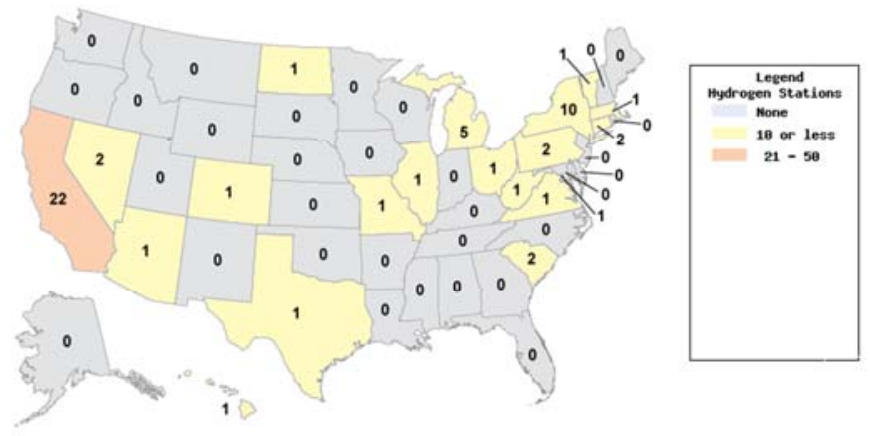

Source: U.S. Department of Energy, Alternative Fuels Data Center

Alternative fuel stations tend to be regionally clustered. E85 stations are concentrated in the Midwest, where more than one-third of the nation's E85 stations have been located since 2004. However, in recent years, new E85 developments outside the Midwest have reduced the strong regional bias. Biodiesel stations are rather heavily concentrated in the Carolinas, which consistently have about one-fifth of the nation's total number of biodiesel stations. The apparent decline in the number of stations from 2007 to 2008 is the result of a change in collection methodology: The station counts from 20052007 include stations offering low-level blends of biodiesel (usually B5); whereas, the 2008 and 2009 numbers only include stations selling B20 and higher blends. Both electric and hydrogen stations are heavily concentrated in California. 
Despite the fact that alternative fuels are not as available as conventional fuels, the amount of energy consumed through alternative fuels increased since 2003 (Table 44). LNG and E85 saw the greatest increases in consumption, while LPG and electricity saw decreases. In both 2005 and 2006, the total consumption of alternative fuels decreased relative to consumption in the year before, primarily due to a significant decrease in the amount of LPG consumed. Despite this decrease in total alternative-fuel consumption, the consumption of ethanol, electricity, and hydrogen combined has increased steadily, climbing to nearly twice its 2003 level by 2007 . These fuels comprise a greater portion of alternative fuels consumed each year

\section{SmartWay encourages efficient heavy truck purchases}

EPA certifies tractors and trailers that incorporate long-haul truck components with significantly lower emissions and fuel consumption. When manufacturers equip long-haul tractors and trailers with these specifications, they are designated and labeled as "U.S. EPA Certified SmartWay." The U.S. EPA Certified SmartWay label may be used at point-of-sale and applied to the interior of the tractors and trailers by the equipment manufacturers.

An EPA-certified SmartWay tractor is characterized by a model year 2007 or later engine; integrated sleeper-cab high roof fairing; tractor-mounted side fairing gap reducers; tractor fuel-tank side fairings; aerodynamic bumper and mirrors; options for reducing periods of extended engine idling (auxiliary power units, generator sets, direct-fired heaters, battery-powered HVAC system, and automatic engine start/stop system); and options for low-rolling resistance tires (single wide or dual) mounted on aluminum wheels. An EPA-certified SmartWay trailer is characterized by side skirts; weight-saving technologies; gap reducer on the front or trailer tails (either extenders or boat tails); and options for low-rolling resistance tires (single wide or dual) mounted on aluminum wheels.

Manufacturers who produce tractors, trailers, or tires that have earned SmartWay certification are shown in Table 45 .
Table 44. Alternative Fuel Consumption

\begin{tabular}{|c|c|c|c|c|c|c|}
\hline Year & 2003 & 2004 & 2005 & 2006 & 2007 & 5-yr $\Delta$ \\
\hline LPG & 224,697 & 211,883 & 188,171 & 173,130 & 152,360 & $-32.2 \%$ \\
\hline CNG & 133,222 & 158,903 & 166,878 & 172,011 & 178,565 & $34.0 \%$ \\
\hline LNG & 13,503 & 20,888 & 22,409 & 23,474 & 24,594 & $82.1 \%$ \\
\hline $\begin{array}{l}85 \% \\
\text { Ethanol } \\
\text { (E85) }\end{array}$ & 26,376 & 31,581 & 38,074 & 44,041 & 54,091 & $105.1 \%$ \\
\hline Electricity & 5,141 & 5,269 & 5,219 & 5,104 & 5,037 & $-2.0 \%$ \\
\hline Hydrogen & 2 & 8 & 25 & 41 & 66 & $3200.0 \%$ \\
\hline $\begin{array}{l}\text { Total } \\
\text { Renewables }\end{array}$ & 31,519 & 36,858 & 43,318 & 49,186 & 59,194 & $87.8 \%$ \\
\hline $\begin{array}{l}\text { Renewables } \\
\text { \% of Total }\end{array}$ & $7.8 \%$ & $8.6 \%$ & $10.3 \%$ & $11.8 \%$ & $14.3 \%$ & \\
\hline Total & 402,941 & 428,532 & 420,776 & 417,801 & 414,713 & $2.9 \%$ \\
\hline
\end{tabular}

Source: DOE Clean Cities Program
Table 45. SmartWay Certified Manufacturers

\begin{tabular}{|c|c|c|}
\hline Tractors & Trailers & Tires \\
\hline Daimler & $\begin{array}{l}\text { Great Dane } \\
\text { Trailers }\end{array}$ & BF Goodrich \\
\hline $\begin{array}{l}\text { Navistar } \\
\text { International }\end{array}$ & Hyundai Translead & Bridgestone \\
\hline Kenworth & Manac Inc. & Continental \\
\hline Mack & $\begin{array}{l}\text { Stoughton Trailers } \\
\text { LLC }\end{array}$ & Double Coin \\
\hline Peterbilt & $\begin{array}{l}\text { Trailmobile } \\
\text { Canada Limited }\end{array}$ & Dunlop Tire \\
\hline \multirow[t]{8}{*}{ Volvo } & $\begin{array}{l}\text { Utility Trailer } \\
\text { Manufacturing } \\
\text { Company }\end{array}$ & Falken \\
\hline & $\begin{array}{l}\text { Vanguard National } \\
\text { Trailer } \\
\text { Corporation }\end{array}$ & Firestone \\
\hline & $\begin{array}{l}\text { Wabash National } \\
\text { Corporation }\end{array}$ & General \\
\hline & & Goodyear \\
\hline & & Hankook \\
\hline & & Michelin \\
\hline & & Toyo Tires \\
\hline & & Yokohama \\
\hline
\end{tabular}

Source: $E P A$ 


\section{Federal subsidies encourage idle reduction technologies}

In order to encourage the use of idling reduction devices in large trucks, the Energy Policy Act of 2005 allowed for a 400-pound weight exemption for the additional weight of idling reduction technology. States were given the discretion of adopting this exemption without being subjected to penalty.

Since then, most States have passed laws which allow trucks to exceed the maximum gross vehicle weight limit by an additional $400 \mathrm{lbs}$ (white States) (Figure 36). Other States have a $400 \mathrm{lb}$ weight allowance which is granted by enforcement personnel (light blue States). Four States have legislation pending at this time (green States) and another four States have not adopted the weight exemption (dark blue States).

Figure 36. States Adopting 400-Pound Weight Exemption for Idling Reduction Devices, 2010

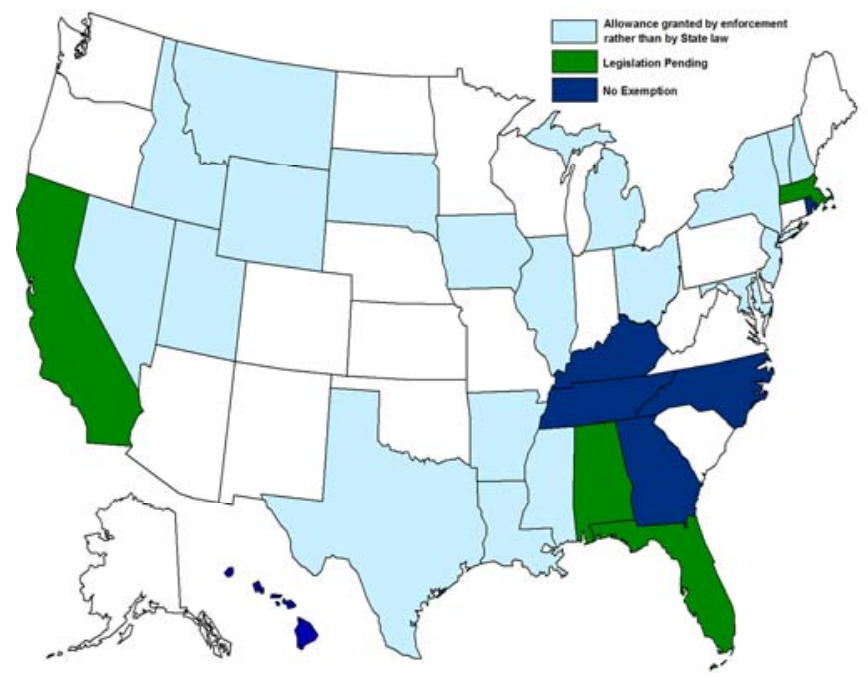

Source: National Idling Reduction News, April 2010.

An additional incentive for equipping large trucks with idle reduction technologies was in the Energy Improvement and Extension Act of 2008. The Act exempts certain idling reduction devices and advanced insulation from Federal excise taxes. Products which are eligible for the tax exemption include:

- fuel operated heaters,

- battery air conditioning/heating systems,

- auxiliary power units/generator sets,

- thermal storage systems, and

- shore connection systems.

\section{Inconsistent policies among states send truck manufacturers mixed signals}

Although all states allow conventional combinations consisting of a 28 -foot semitrailer and a 28 -foot trailer, only 14 states and six state turnpike authorities allow longer combination vehicles (LCVs) on at least some parts of their road networks. LCVs are tractors pulling a semitrailer longer than 28 feet and a trailer longer than 28 feet; a semitrailer longer than 28 feet and a trailer no more than 28 feet long; or a 28 -foot semitrailer and two 28-foot trailers. The routes along which these LCVs can travel are shown in Figure 37. Allowable routes for LCVs have been frozen since 1991.

The maximum truck speed limit is inconsistent among states (Figure 38). It ranges from $55 \mathrm{mph}$ in three places (California, Oregon, and the District of Columbia) to 80 mph on certain roads in Utah. This 25 -mph span means that there is not one common highway speed at which trucks travel. This multitude of speeds precludes truck manufacturers from engineering truck engines that peak in efficiency after reaching the speed at which the vehicles most commonly travel. Instead, manufacturers design the vehicle to perform well over the entire range. Experts have estimated that a common nationwide speed limit would enable manufacturers to fine-tune engine efficiency to increase fuel economy by $5 \%$ to $10 \%$.

\section{Figure 37. Routes Permitting Longer Combination Vehicles}

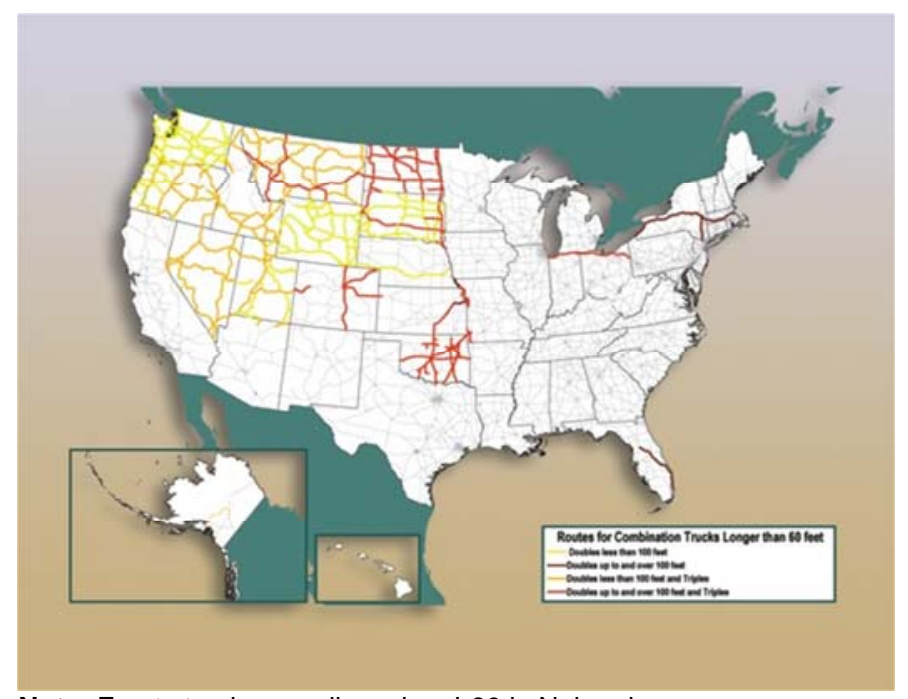

Note: Empty trucks are allowed on I-80 in Nebraska.

Source: FHWA, Office of Freight Management and Operations 


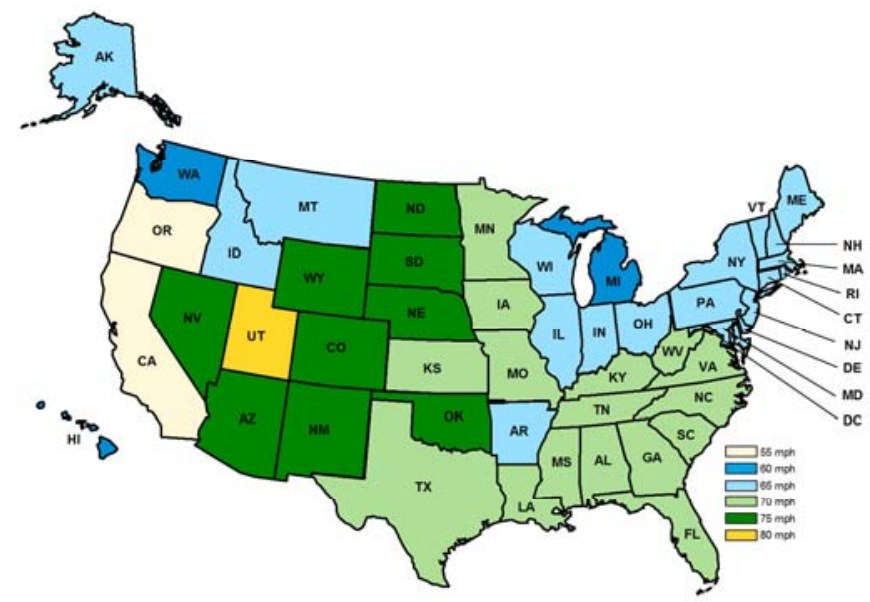

Source: Insurance Institute for Highway Safety, Highway Loss Data Institute, October 2010.

\section{The nation's largest commercial fleets include advanced technology vehicles}

With close to 9 million vehicles, commercial fleetscomprised of both light and heavy vehicles-account for about $4 \%$ of the vehicles in the United States today. The prevalence of alternative fuel vehicles within some fleets can be much higher than the national average. Commercial entities buy alternative fuel vehicles to demonstrate their environmental and energy consciousness to their clients and the general public.

Merck \& Company, Inc., a pharmaceutical company, has the largest alternative fuel fleet; nearly all are flexible fuel vehicles. Schwan's Home Service Inc., a ready-made meal- and grocery-delivery company, also has a large alternative fuel vehicle fleet, which is comprised entirely of propane or propane bi-fuel vehicles (Table 46). A power company, National Grid, drives the fleet with the most natural gas-powered vehicles, and Johnson \& Johnson drives the most hybrid-electric or all-electric vehicles. Nearly half of Delta airlines fleet are hybrid-electric or allelectric vehicles.

Nearly one quarter of Federal Government vehicles run on alternative fuels.

In 2009, the Federal Government owned over 650,000 vehicles; twenty-four percent of those vehicles were alternative fuel vehicles (Table 47). The alternative fuel fleet is predominantly made up of flex-fuel E-85 vehicles, though the Government owns vehicles that run on many different types of fuels. Unlike commercial fleets which tend to have only one or two different types of alternative fuel vehicles, the Federal Government owns vehicles that can run on six different fuels, not counting the gasoline and diesel fuel which run in hybrid engines. 
Table 46. Commercial Fleet Alternative Fuel and Advanced Technology Vehicles

\begin{tabular}{|c|c|c|c|c|c|c|c|c|c|c|}
\hline & Company & 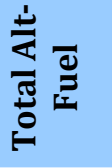 & $\bigcup_{3}^{*}$ & 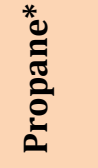 & $\begin{array}{l}\bar{d} \\
\stackrel{5}{\dot{x}} \\
\frac{0}{x}\end{array}$ & 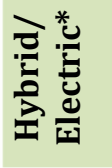 & 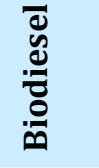 & 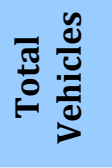 & 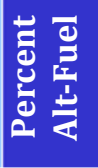 & 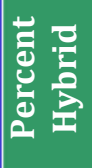 \\
\hline 1 & Merck \& Co., Inc. & 5,849 & & & 5,800 & 49 & & 7,317 & $80 \%$ & $1 \%$ \\
\hline 2 & Schwan's Home Service Inc. & 5,800 & & 5,800 & & & & 6,094 & $95 \%$ & $0 \%$ \\
\hline 3 & State Farm Mutual Auto Insurance Co & 4,471 & & & 4,339 & 131 & 1 & 14,376 & $31 \%$ & $1 \%$ \\
\hline 4 & GE Healthcare & 3,875 & & & 3,875 & & & 5,614 & $69 \%$ & $0 \%$ \\
\hline 5 & Xerox Corp. & 3,825 & & & 3,675 & 150 & & 10,450 & $37 \%$ & $1 \%$ \\
\hline 6 & Bristol-Myers Squibb Co. & 3,562 & & & 3,550 & 12 & & 5,557 & $64 \%$ & $0 \%$ \\
\hline 7 & Ferrellgas & 3,530 & & 3,530 & & & & 3,733 & $95 \%$ & $0 \%$ \\
\hline 8 & Eli Lilly \& Co. & 3,174 & & & 3,000 & & 174 & 5,113 & $62 \%$ & $0 \%$ \\
\hline 9 & Johnson \& Johnson Services Inc. & 3,037 & & & 912 & 2,125 & & 9,850 & $31 \%$ & $22 \%$ \\
\hline 10 & Honeywell International Inc. & 2,319 & & & 2,319 & & & 4,189 & $55 \%$ & $0 \%$ \\
\hline 11 & Consolidated Edison Company of NY & 1,804 & 20 & & & 23 & 1,761 & 3,608 & $50 \%$ & $1 \%$ \\
\hline 12 & Florida Power \& Light & 1,524 & & & 10 & 263 & 1,251 & 1,851 & $82 \%$ & $14 \%$ \\
\hline 13 & United Parcel Service (UPS) & 1,448 & 725 & 720 & & 3 & & 72,633 & $2 \%$ & $0 \%$ \\
\hline 14 & DSWaters of America & 1,236 & & 1,131 & & 105 & & 1,573 & $78 \%$ & $7 \%$ \\
\hline 15 & Monsanto Co. & 1,131 & & & 1,125 & 6 & & 3,365 & $34 \%$ & $0 \%$ \\
\hline 16 & Liberty Mutual Insurance & 1,018 & & & 1,018 & & & 3,505 & $29 \%$ & $0 \%$ \\
\hline 17 & Delta Airlines & 861 & 4 & 124 & 0 & 733 & & 1,546 & $56 \%$ & $47 \%$ \\
\hline 18 & Comcast Corp. & 852 & & & 756 & 96 & & 40,158 & $2 \%$ & $0 \%$ \\
\hline 19 & National Grid & 832 & 730 & 15 & 52 & 35 & & 3,000 & $28 \%$ & $1 \%$ \\
\hline 20 & Ecolab Inc. & 809 & & & 809 & & & 7,311 & $11 \%$ & $0 \%$ \\
\hline 21 & Alliant Energy & 804 & & & 4 & & 800 & 1,837 & $44 \%$ & $0 \%$ \\
\hline 22 & Novartis Pharmaceuticals & 797 & & & & 797 & & 8,102 & $10 \%$ & $10 \%$ \\
\hline 23 & Federal Express Corp. & 786 & 90 & 696 & & & & 36,701 & $2 \%$ & $0 \%$ \\
\hline 24 & Schneider Electric/Square D & 770 & & & 750 & 20 & & 1,535 & $50 \%$ & $1 \%$ \\
\hline 25 & BMHC (BMC West/SelectBuild) & 738 & & 418 & 315 & 5 & & 2,670 & $28 \%$ & $0 \%$ \\
\hline 26 & Cox Enterprises Inc. & 676 & 6 & & 413 & 257 & & 13,130 & $5 \%$ & $2 \%$ \\
\hline 27 & Land O' Lakes Inc. & 601 & & & 600 & 1 & & 941 & $64 \%$ & $0 \%$ \\
\hline 28 & University of Michigan & 578 & & & 483 & 5 & 90 & 1,081 & $53 \%$ & $0 \%$ \\
\hline 29 & Xcel Energy & 578 & 112 & 7 & 102 & 4 & 353 & 3,280 & $18 \%$ & $0 \%$ \\
\hline 30 & Los Angeles World Airports & 536 & 436 & 38 & & 62 & & $\mathrm{~N} / \mathrm{A}$ & $\mathrm{N} / \mathrm{A}$ & $\mathrm{N} / \mathrm{A}$ \\
\hline 31 & Southwest Gas Corp. & 528 & 430 & & 89 & 9 & & 1,804 & $29 \%$ & $0 \%$ \\
\hline 32 & Questar Gas Company & 502 & 502 & & & & & $\mathrm{~N} / \mathrm{A}$ & N/A & N/A \\
\hline 33 & PPG Industries & 500 & & & 500 & & & 2,577 & $19 \%$ & $0 \%$ \\
\hline 34 & JEA Fleet Services & 488 & & & 54 & 9 & 425 & 774 & $63 \%$ & $1 \%$ \\
\hline 35 & Dallas/Fort Worth International Airport & 473 & 420 & 8 & & 27 & 18 & N/A & N/A & N/A \\
\hline 36 & Consolidated Coca-Cola Bottling & 402 & & & & 402 & & 2,537 & $16 \%$ & $16 \%$ \\
\hline 37 & University of California, San Diego & 394 & 9 & & & 335 & 50 & 910 & $43 \%$ & $37 \%$ \\
\hline 38 & Peoples Gas Light and Coke Co. & 352 & 352 & & & & & N/A & N/A & N/A \\
\hline 39 & Roche & 339 & 97 & & & 242 & & 1,906 & $18 \%$ & $13 \%$ \\
\hline 40 & Archer Daniels Midland & 325 & & & 200 & & 125 & 1,300 & $25 \%$ & $0 \%$ \\
\hline 41 & University of California Los Angeles & 308 & 58 & 5 & & 244 & 1 & $\mathrm{~N} / \mathrm{A}$ & $\mathrm{N} / \mathrm{A}$ & $\mathrm{N} / \mathrm{A}$ \\
\hline 42 & University of Washington & 308 & & & 225 & 35 & 48 & 712 & $43 \%$ & $5 \%$ \\
\hline 43 & American Family Mutual Insurance Inc. & 271 & & & 268 & 3 & & 1,417 & $19 \%$ & $0 \%$ \\
\hline 44 & University of California Davis & 269 & 71 & & 65 & 73 & 60 & 800 & $34 \%$ & $9 \%$ \\
\hline 45 & Nicor Gas & 252 & 26 & & 226 & & & 1,580 & $16 \%$ & $0 \%$ \\
\hline 46 & University of Iowa & 228 & & & 190 & & 38 & $\mathrm{~N} / \mathrm{A}$ & $\mathrm{N} / \mathrm{A}$ & N/A \\
\hline 47 & Santee Cooper & 210 & & 133 & & 77 & & $\mathrm{~N} / \mathrm{A}$ & $28 \%$ & N/A \\
\hline 48 & Toshiba America Medical Systems & 150 & & 150 & & & & 530 & N/A & $0 \%$ \\
\hline 49 & Anixter Inc. & 150 & & 150 & & & & 525 & $29 \%$ & $0 \%$ \\
\hline 50 & Walgreens & 138 & & 138 & & & & 3,018 & $5 \%$ & $0 \%$ \\
\hline
\end{tabular}

Source: "Top 50 Green Commercial Fleets," AUTOMOTIVE FLEET 500 / 2008

*Includes dedicated and bi-fuel vehicles. 
Table 47. Federal Government-Owned Fleet Vehicles by Fuel Type

\begin{tabular}{|l|c|c|r|r|r|}
\hline Fuel Type & $\mathbf{2 0 0 5}$ & $\mathbf{2 0 0 6}$ & $\mathbf{2 0 0 7}$ & $\mathbf{2 0 0 8}$ & \multicolumn{1}{|c|}{$\mathbf{2 0 0 9}$} \\
\hline CNG & 12,137 & 10,772 & 9,288 & 8,210 & 6,486 \\
\hline Diesel & 82,687 & 79,954 & 83,285 & 84,326 & 83,794 \\
\hline Diesel Hybrid & $*$ & $*$ & $*$ & $*$ & 53 \\
\hline E-85 & 82,864 & 96,229 & 113,046 & 129,858 & 143,652 \\
\hline Electric & 185 & 111 & 100 & 83 & 57 \\
\hline Gasoline & 454,452 & 443,318 & 436,168 & 422,758 & 411,870 \\
\hline Gasoline Hybrid & $*$ & $*$ & $*$ & $*$ & 5,582 \\
\hline LNG & 51 & 64 & 34 & 33 & 20 \\
\hline LPG & 312 & 292 & 312 & 221 & 185 \\
\hline Hydrogen & 0 & 0 & 0 & 2 & 4 \\
\hline Total & & & & \\
\hline
\end{tabular}

Source: General Services Administration, Federal Fleet Report 2005-2009.

\section{Coming up in $2011-2015$}

As the preceding sections have shown, the economic recession of 2008 and 2009 took an especially hard toll on the American automotive industry. In the coming years, as the economy is expected to recover, so are automotive manufacturers and suppliers. Additionally, the Energy Independence and Security Act (EISA) of 2007 combined with the Obama Administration's direction to accelerate planned fuel economy regulations spell big news for the coming years: auto manufacturers are required to increase fuel economy significantly through 2016 and potentially beyond. Thus, although uncertainty surrounds the technologies, fuel economy improvement is - at present-a legal certainty. The following sections show in what vehicles and by what dates commercialization of emerging technologies is expected to occur in combustion, alternative fuels, and HEVs during the next five years.

\section{Light-vehicle CAFE standards will become more stringent}

EISA 2007 sets an ambitious goal for the national fuel economy standard of $35 \mathrm{mpg}$ by 2020 , an increase of $40 \%$. This increase marks the first instance that CAFE standards have increased above the levels established when they were created in 1975.

For MY 2012 through MY 2016, NHTSA and EPA issued joint rulemaking to establish a new National program to regulate fuel economy and greenhouse gas emissions. The intention is not only to regulate cars and light trucks in this new program, but also medium and heavy vehicles, which have never been subject to fuel economy standards before.
On March 30, 2009, NHTSA published the final rule for MY 2011 by raising CAFE standards for both cars and light trucks. In this rule, the fuel economy targets are based on the size of the vehicle as measured by the vehicle footprint [the distance between the wheels (width) multiplied by the distance between the axles (length)]. NHTSA estimates that the new standards will save 887 million gallons of fuel over the lifetime of the MY 2011 cars and light trucks and reduce $\mathrm{CO}_{2}$ emissions by $8.3 \mathrm{MMT}$ during that time. The average standards are shown in Figure 39. Each manufacturer will have a slightly different standard to meet based on how its average footprint varies from the total average footprint. NHTSA is researching proposed standards for future model years. 
Figure 39. Average CAFE Standards for MY 20122016

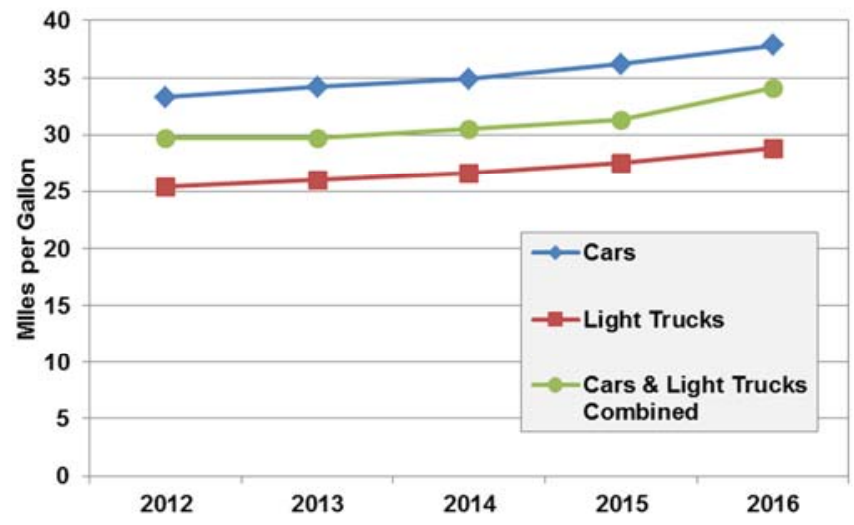

Source: Federal Register, Vol. 74, No. 186, September 2009

\section{New heavy-truck fuel consumption and emissions standards will be finalized}

In November 2010, the EPA and NHTSA proposed new regulations on the fuel economy and greenhouse gas emissions of combination tractors, heavy-duty pickups and vans, and vocational vehicles. The standards would be phased in beginning in MY2014 and be in effect through at least 2017. There are differentiated standards for various subcategories of trucks and different methodologies of calculating standards for heavier trucks as opposed to the lighter trucks. Figure 40 shows the proposed CO2 standards for MY2017 for the different truck categories. Vocational vehicles include trucks such as smaller and larger van trucks, utility "bucket" trucks, tank trucks, refuse trucks, urban and over-the-road buses, fire trucks, flatbed trucks, and dump trucks, among others. The proposed fuel consumption standards follow in Figure 41.

Figure 40. Proposed CO2 Standards for MY 2017

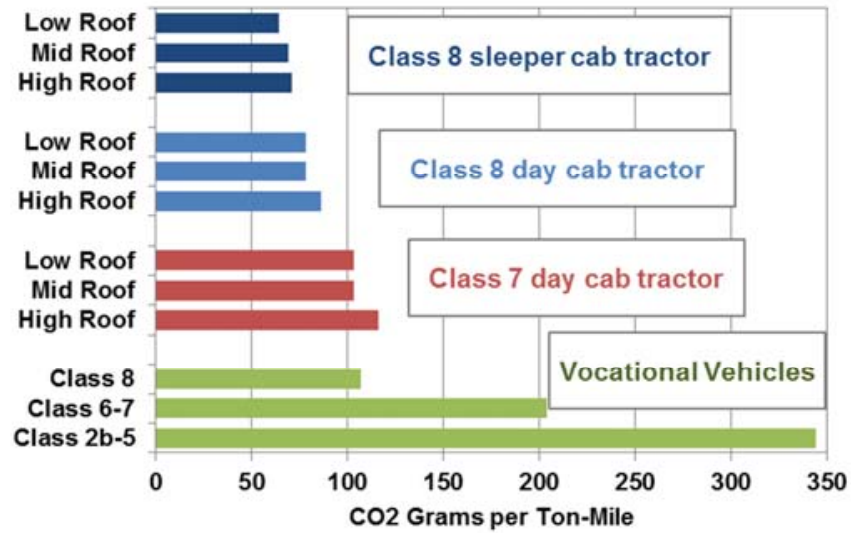

Source: Federal Register, Vol. 75, No. 229
Figure 41. Proposed Fuel Consumption Standards for MY 2017

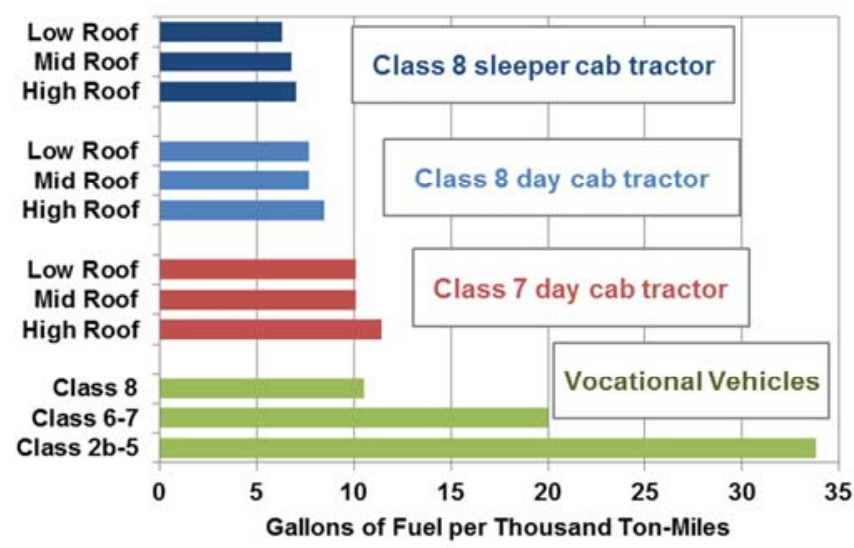

Source: Federal Register, Vol. 75, No. 229

\section{New heavy-truck technologies will be deployed in response to tighter fuel economy and emissions regulations}

As a precursor to the Federal heavy truck fuel economy/greenhouse gas emission standards recently announced, NAS produced a study of the technologies and approaches to reducing fuel consumption in medium and heavy trucks. They determined that the most effective technologies in terms of fuel consumption reduction are:

- Hybridization;

- Replacement of gasoline engines with diesel engines;

- Improvement in diesel engine thermal efficiency;

- Improvement in gasoline engine thermal efficiency;

- Aerodynamics, especially on tractor-trailer applications;

- Reduced rolling resistance;

- Weight reduction.

A myriad of technologies were evaluated in the NAS study. Figure 42 shows seven fuel reduction methods and their potential for savings on various types of trucks in the 2015 to 2020 time frame. Hybridization and other engine technologies show the most promise for reducing fuel consumption in the coming years. "Management and Coaching" represent the fuel economy gains made possible by education truck drivers how to drive efficiently (smart acceleration, etc.). 
Figure 42. Comparison of 2015 - 2020 New Vehicle Potential Fuel Savings Technology by Truck Type

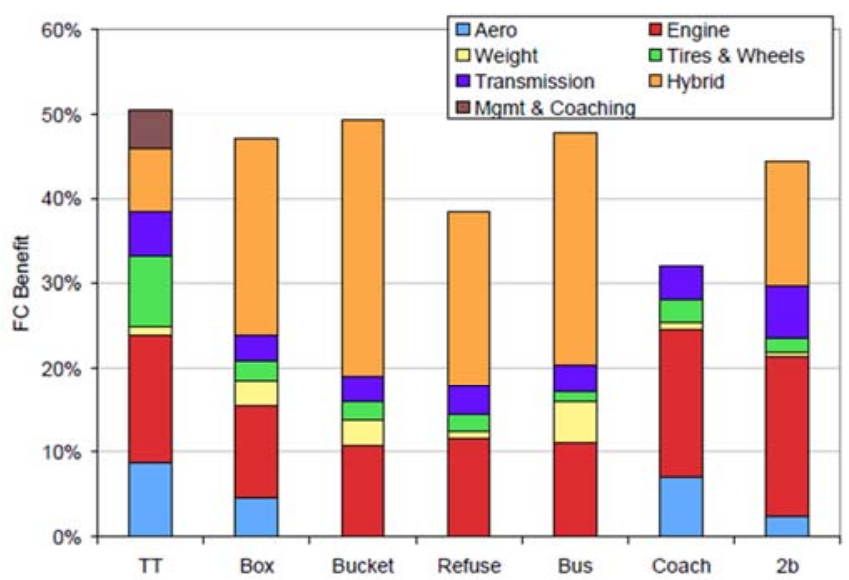

Note: FC Benefit $=$ fuel consumption benefit. Aero = aerodynamics. Mgmt $=$ management .

Source: National Research Council, Transportation Research Board, Technologies and Approaches to Reducing the Fuel Consumption of Medium- and Heavy-Duty Vehicles Committee to Assess Fuel Economy Technologies for Medium- and Heavy-Duty Vehicles

\section{Electric drive offerings will diversify and expand significantly}

The number of electric drive vehicles will increase significantly in the near future with planned increases in HEV production and the expected introduction of plug-in HEVs at the end of 2010. Electric drive concept and production vehicles that have been announced for possible release within the next five years and the characteristics of each, where known, are summarized in Table 48.

Additionally, a greater number of batteries used in light vehicles are expected to be produced in the United States. The 2009 American Reinvestment and Recovery Act invested $\$ 2$ billion in domestic battery manufacturing facilities, and these facilities, which have been under construction since awards were made in 2010, will soon begin producing batteries. The Administration has stated as its goal sufficient domestic vehicle battery production capacity to supply 500,000 electric-drive vehicles each year.

\section{Medium- and heavy-truck sales have suffered through the recession but will recover with the economy}

The economic recession of 2008-2009 severely affected the trucking industry: New Class 8 truck sales in 2009 were 95,000 units, down nearly $30 \%$ from 133,000 in 2008. The hard times for medium and heavy trucking are underscored by the difficulties that the freight-drivers are experiencing. Limited output in domestic manufacturing, construction, agricultural commodities, mining, and non-oil merchandise imports constrain demand for freight transport, and, therefore, for new medium and heavy trucks. Engine production volumes were at historical lows into 2009. As industries that drive freight transportation recover, fleets are expected to increase buying engine and vehicles to make up for the lag during the recession. In 2010, the production of class 6-8 trucks rose $11 \%$ and freight tonnage increased by that same amount. Truck sales volumes tend to increase just ahead of increases in GDP, thus as the economy recovers, truck sales are expected to rise.

\section{Heavy-truck use of advanced fuels will expand, but slowly}

No significant changes to current diesel fuels are anticipated; although the availability of B5, which is accepted by all diesel engine manufacturers, is expected to expand over time. Furthermore, some states are considering proposals that may lead to higher biodiesel blends. Manufacturers are quick to point out that the durability of engines when using such blends is not known. Testing and characterization of engines using higher biodiesel blends would likely delay the implementation of any legislation designed to increase the amount of biofuel included in diesel fuel blends at the pump.

Penetration of natural gas engines is growing for urban bus markets. This trend is expected to continue.

\section{Natural gas production in the United States will grow}

Due to the large natural gas discovery in Louisiana in 2009 , the outlook for natural gas has changed significantly. As recent as 2006, predictions were that natural gas production was on a steady decline. But the new large discoveries (not only in Louisiana, but in other states, too) along with new technologies, have changed the outlook.

With the increase in U.S. natural gas production, the outlook is more favorable for natural gas vehicles to replace conventional vehicles in the future, especially in medium and heavy vehicle applications that have access to central refueling stations. The number of light-duty natural gas vehicles for sale to the public by the OEMs has dwindled; in the 2011 model year, the Honda Civic GX is the only light-duty CNG vehicle offered. However, a rise in natural gas production, and the price decline that will follow, may lead to a brighter future for natural gas as a transportation fuel. 
Table 48. (P)HEV Demonstration and Upcoming Models

\begin{tabular}{|c|c|c|c|c|c|c|c|c|}
\hline Organization & $\begin{array}{l}\text { Specific Product(s) } \\
\text { Planned }\end{array}$ & $\begin{array}{c}\text { US } \\
\text { Release }\end{array}$ & MPG & AER & Engine & Battery & Motor & Additional \\
\hline AFS Trinity & XH-150 Extreme Hybrid & 2013-2014 & 150 & 40 & & Li-Ion & $8 \mathrm{kWh}$ & electric traction motor \\
\hline Aptera Motors & Aptera 2e & Late 2011 & 350 & 100 & & $10-13 \mathrm{kWh}$ & & $\begin{array}{l}\text { gas, electric and PHEV } \\
\text { models planned }\end{array}$ \\
\hline Audi & R8 E-tron & Late 2012 & 107 & 31 & TDI V6 & Li-Ion & $\begin{array}{l}230 \mathrm{kWh} \\
\text { combined }\end{array}$ & 4 asynchronous motors \\
\hline Balqon Corp. & Mule M-150 & Available & & 150 & & $280 \mathrm{kWhr}$ & $300 \mathrm{hp}$ & electric motor \\
\hline Balqon Corp. & XE20 Yard Tractor & Available & & 60 & & $140 \mathrm{kWhr}$ & $200 \mathrm{hp}$ & electric motor \\
\hline Balqon Corp. & XE30 Yard Tractor & Available & & 150 & & $280 \mathrm{kWhr}$ & $300 \mathrm{hp}$ & electric motor \\
\hline BMW & Megacity & 2013 & & 160 & & $35 \mathrm{kWh}$ & $150 \mathrm{hp}$ & electric motor \\
\hline BMW & Mini-E & 2013 & & 156 & & 35 kWh Li-ion & $150 \mathrm{~kW}$ & electric motor \\
\hline BMW & Vision Efficient Dynamics & 2013 & 60.6 & 31 & $\begin{array}{l}1.5 \mathrm{~L} \\
\text { turbodiesel }\end{array}$ & Li-Ion, $10.8 \mathrm{kWh}$ & $\begin{array}{l}33 \mathrm{hp} \mathrm{\&} \\
80 \mathrm{hp}\end{array}$ & two electric motors \\
\hline BYD & e6 & 2011 & 205 & 186 & & $75 \mathrm{~kW}-160 \mathrm{~kW}$ & $75 / 450$ & electric motor \\
\hline BYD & F6-DM & $\mathrm{N} / \mathrm{A}$ & & 60 & $2.0-2.4 \mathrm{~L}$ & $\begin{array}{l}\text { lithium iron } \\
\text { phosphae }\end{array}$ & & \\
\hline BYD & F3-DM & 2012 & & 60 & $1.6 \mathrm{~L}$ & $\mathrm{Fe}$ & $50 \mathrm{hp}$ & dual mode \\
\hline Chrysler LLC & ecoVoyager & Concept & 300 & 40 & & Li-ion & $\begin{array}{l}286 \mathrm{hp} \\
\text { electric }\end{array}$ & \\
\hline Chrysler & Fiat $500 \mathrm{EV}$ & 2012 & 59 & 50 & & Li-ion & & \\
\hline Chrysler LLC & Jeep Renegade PHEV & Concept & $\begin{array}{l}110 \\
\text { equiv }\end{array}$ & 40 & $1.5 \mathrm{~L} 3 \mathrm{cyl}$ & Li-ion & $268 \mathrm{hp}$ & electric motor \\
\hline Chrysler LLC & $\begin{array}{l}\text { Jeep Wrangler Range } \\
\text { Extended EV }\end{array}$ & $2010 / 2011$ & 50 & 40 & 1.0L 3-4 cyl & 27 kWh Li-ion & $268 \mathrm{hp}$ & \\
\hline Chrysler LLC & $\begin{array}{l}\text { Chrysler Town \& Country } \\
\text { EV minivan }\end{array}$ & $2010 / 2011$ & 50 & 40 & $1.0 \mathrm{~L} \mathrm{3-4} \mathrm{cyl}$ & 22 kWh Li-ion & $190 \mathrm{~kW}$ & \\
\hline Citroen & C-ZERO & Late 2010 & & 80 & & 330 volt Li-ion & $\begin{array}{l}47 \mathrm{~kW} \\
64 \mathrm{hp}\end{array}$ & $\begin{array}{l}\text { permanent magnet } \\
\text { synchronous motor }\end{array}$ \\
\hline Citroen & Survolt & Prototype & & 124 & & 140 Li-Ion (2) & $300 \mathrm{hp}$ & $\begin{array}{l}\text { race car } \mathrm{w} / \text { two electric } \\
\text { motors }\end{array}$ \\
\hline $\begin{array}{l}\text { Coda } \\
\text { Automotive }\end{array}$ & Coda Electric Sedan & End 2011 & & 100 & & 33.8 kWh Li-ion & & $\begin{array}{l}100 \mathrm{~kW} \text { electric drive } \\
\text { system }\end{array}$ \\
\hline Daimler & MT-WIV & 2011 & & 100 & & 120 kW Li-ion & & all electric, walk-in van \\
\hline $\begin{array}{l}\text { Daimler } \\
\text { (w/ EPRI) }\end{array}$ & Sprinter PHEV Van & $\mathrm{N} / \mathrm{A}$ & & 20 & 2.7L or $2.3 \mathrm{~L} \mathrm{D}$ & NiMH or Li-Ion & $90 \mathrm{~kW}$ & \\
\hline Daimler & $\begin{array}{l}\text { Smart ED ForTwo Electric } \\
\text { Vehicle }\end{array}$ & 2012 & & 100 & & 16.5 kWh Li-Ion & $30 \mathrm{~kW}$ & \\
\hline Dodge & Circuit EV & 2013 & & $\begin{array}{l}150- \\
120\end{array}$ & & Li-Ion? & $200 \mathrm{~kW}$ & electric \\
\hline Exagon & Furtive e-GT & Late 2012 & & $\begin{array}{l}122- \\
252\end{array}$ & & VL $4-125 \mathrm{~kW}$ & $340 \mathrm{hp}$ & dual engines \\
\hline $\begin{array}{l}\text { Enova } \\
\text { Systems }\end{array}$ & PHEV School Bus & available & & & VT365 V8 D & & & electric motor \\
\hline Eaton & medium-duty trucks & available & & & multiple & multiple & multiple & \\
\hline ePower & XT320E & available & & $60 \times 2$ & & $\begin{array}{l}213 \mathrm{kWh} \\
\text { swappable }\end{array}$ & & all electric \\
\hline $\begin{array}{l}\text { Fisker } \\
\text { Automotive }\end{array}$ & $\begin{array}{l}\text { Quantum Karma Plug-In } \\
\text { Hybrid }\end{array}$ & 2011 & 100 & 50 & $\begin{array}{l}2.0 \mathrm{~L} \text { direct } \\
\text { injection }\end{array}$ & Li-ion & $201 \mathrm{hp} \mathrm{(2)}$ & \\
\hline $\begin{array}{l}\text { Ford (w/ } \\
\text { DOE) }\end{array}$ & AirStream HySeries & Concept & 305 & 25 & & 336 V Li-ion & & $\begin{array}{l}\text { hydrogen-powered fuel } \\
\text { cell }\end{array}$ \\
\hline Ford & C-Max PHEV & 2012 & & & $\begin{array}{l}1.6-2.0 \mathrm{~L} \\
4 \text { cyl }\end{array}$ & Li-ion & & \\
\hline $\begin{array}{l}\text { Ford }(w / \\
\text { DOE) }\end{array}$ & Ford F-550 Trouble Truck & 2011 & & 10 & & Li-ion & & \\
\hline $\begin{array}{l}\text { Ford (w/EPRI, } \\
\text { Southern CA } \\
\text { Edison \& } \\
\text { Argonne } \\
\text { National Lab.) }\end{array}$ & PHEV Escape & 2012 & 120 & 30 & 2.3L 4 cyl & 10 kWh Li-ion & & $\begin{array}{l}\text { internal combustion } \\
\text { engine }\end{array}$ \\
\hline Ford & Focus EV & End 2011 & & 100 & & $\begin{array}{l}23 \mathrm{kWh} \text { liquid } \\
\text { cooled }\end{array}$ & & \\
\hline Ford & Transit Connect EV & 2011 & & 80 & & 28 kWh Li-ion & $28 \mathrm{kWH}$ & \\
\hline
\end{tabular}

(Continued on next page) 
Table 48. (P)HEV Demonstration and Upcoming Models (Continued)

\begin{tabular}{|c|c|c|c|c|c|c|c|c|}
\hline Organization & $\begin{array}{l}\text { Specific Product(s) } \\
\text { Planned }\end{array}$ & $\begin{array}{c}\text { US } \\
\text { Release }\end{array}$ & MPG & AER & Engine & Battery & Motor & Additional \\
\hline $\begin{array}{l}\text { General } \\
\text { Motors }\end{array}$ & Cadillac Provoq & Concept & 300 & 20 & & Li-ion & & $\begin{array}{l}\text { 5th generation hydrogen } \\
\text { fuel cell }\end{array}$ \\
\hline $\begin{array}{l}\text { General } \\
\text { Motors }\end{array}$ & Chevrolet Volt & available & $35-40$ & $25-50$ & $1.4 \mathrm{~L} 4 \mathrm{cyl}$ & 16 kWh Li-ion & 150-hp electric & backup generator \\
\hline $\begin{array}{l}\text { General } \\
\text { Motors }\end{array}$ & Opel Ampera & 2011 & 311 & 37 & & 16 kWh Li-ion & 150-hp electric & "range extender" \\
\hline Hyundai & BLUE-WILL & 2012 & 55 & $20-40$ & $1.6 \mathrm{~L}$ & lithium polymer & $100 \mathrm{~kW}$ electric & \\
\hline Infiniti & M35h & 2012 & 32.2 & & $67 \mathrm{hp} \mathrm{3.5L} \mathrm{V6}$ & 1.3 kWh Li-Ion & $50 \mathrm{~kW}$ electric & \\
\hline Jaguar & $\mathrm{C}-\mathrm{X} 75$ & Concept & 560 & 68 & $2 @ 145 \mathrm{~kW}$ & plug in Li-Ion & $580 \mathrm{~kW}$ total & $4195 \mathrm{hp}$ electric motors \\
\hline Kia & Electric SUV & 2013 & & 80 & & & & \\
\hline Land Rover & Land Rover LRX & Late 2011 & 49.9 & & & & & C02 Offset Program \\
\hline Land Rover & Land Rover range_3 & 2013 & & 20 & 3.0L V6 & Li-Ion & $25 \mathrm{~kW}$ electric & plug-in diesel \\
\hline Lotus & Lotus CityCar Concept & Late 2013 & 200 & 35 & $1.2 \mathrm{~L} 3 \mathrm{cyl}$ & Li-Ion & & plug-in hybrid powertrain \\
\hline $\begin{array}{l}\text { Mercedes- } \\
\text { Benz }\end{array}$ & Vito E-Cell & 2011 & & 80 & $4-6 \mathrm{cyl}$ & 32 kWh Li-Ion & $60 \mathrm{~kW}$ electric & \\
\hline Mitsubishi & $\begin{array}{l}\text { Innovative Electric Vehicle } \\
\text { (iMiEV) }\end{array}$ & 2011 & & $\begin{array}{l}80- \\
100\end{array}$ & & $330 \mathrm{~V} 16 \mathrm{kWh}$ & & all electric \\
\hline $\begin{array}{l}\text { Mitsubishi- } \\
\text { Fuso }\end{array}$ & Canter E-CELL & Concept & & 74.5 & & 40 kWh Li-Ion & $70 \mathrm{~kW}$ & \\
\hline Navistar & eStar Delivery Vehicle & available & & 100 & & $\begin{array}{l}80 \mathrm{kWhr} \text { Li-Ion } \\
\text { Cassette }\end{array}$ & 70kW 102 hp & all electric \\
\hline Nissan & PHEV & 2012 & 300 & 100 & & 24 kWh Li-Ion & & \\
\hline Nissan & Leaf & available & & $\begin{array}{l}62- \\
138\end{array}$ & & 24 kWh Li-Ion & $\begin{array}{l}80 \mathrm{~kW} \\
\text { synchronous }\end{array}$ & all electric \\
\hline $\begin{array}{l}\text { Optimal } \\
\text { Energy }\end{array}$ & Joule EV & 2014 & & 143 & & $\begin{array}{l}36 \mathrm{kWh} \mathrm{Li-ion} \\
\text { traction }\end{array}$ & $75 \mathrm{~kW}$ & all electric \\
\hline Pininfarina & Bluecar & 2011 & & 155 & & L.M.P. & $50 \mathrm{~kW}$ electric & electric \\
\hline Proterra & EcoRide BE35 & available & & 30 & & 72 kW-h Li-Ion & $\begin{array}{l}150 \mathrm{PM} \\
150 \mathrm{~kW}\end{array}$ & electric bus \\
\hline Proterra & $\begin{array}{l}\text { HFC35 Plug-in Hybrid Fuel } \\
\text { Cell Bus }\end{array}$ & available & & 250 & & & $150 \mathrm{~kW}$ & $\begin{array}{l}\text { hydrogen-powered fuel } \\
\text { cell }\end{array}$ \\
\hline $\begin{array}{l}\text { Raser } \\
\text { Technologies }\end{array}$ & Hummer H3 & 2011 & 100 & 40 & 2.0L turbo & $\begin{array}{l}3 \text { Li-ion battery } \\
\text { packs }\end{array}$ & $200 \mathrm{~kW}$ & $100 \mathrm{~kW}$ generator \\
\hline $\begin{array}{l}\text { Smith } \\
\text { Technologies }\end{array}$ & Newton Electric Truck & 2010 & & 100 & & $\begin{array}{l}80-120 \mathrm{kwh} \\
\text { Li-Ion }\end{array}$ & 120kw Electric & \\
\hline Tessla & Roadster & 2011 & & 245 & $\begin{array}{l}375 \text { Volt } \mathrm{AC} \\
\text { Induction }\end{array}$ & Li-Ion & $\begin{array}{l}\text { air-cooled } \\
\text { electric }\end{array}$ & \\
\hline Tessla & Model S & 2012 & & $\begin{array}{l}160- \\
300\end{array}$ & & $42-95 \mathrm{kWh}$ & & $\begin{array}{l}45 \text { minute quick charge - } \\
14 \mathrm{hr} \text { charge ( } 95 \mathrm{kWh})\end{array}$ \\
\hline Toyota & Prius PHEV & 2012 & 50 & 13 & & $5.2 \mathrm{hWh}$ & & \\
\hline Velozzi & Solo Crossover & 2011 & 1,000 & 200 & $\begin{array}{l}\text { 770-hp AC- } \\
\text { induction } \\
\text { electric }\end{array}$ & $\begin{array}{l}30-\mathrm{kW} \\
\text { microturbine }\end{array}$ & & \\
\hline Volkswagen & E-Up & 2013 & & 80 & & 18 kWh Li-ion & $50 \mathrm{~kW}$ electric & \\
\hline Volkswagen & Golf TwinDrive & 2011 & & 30 & & Li-Ion & $82 \mathrm{hp}$ electric & $\begin{array}{l}\text { TwinDrive connected } \\
\text { directly to gasoline engine }\end{array}$ \\
\hline Volvo & ReCharge & 2012 & & 60 & & & & \\
\hline Volvo & $\begin{array}{l}\text { Volvo C } 30 \text { Battery Electric } \\
\text { Vehicle }\end{array}$ & 2013 & & 90 & & $\begin{array}{l}24 \mathrm{KWh}, 617 \mathrm{lb} \\
\text { Li-Ion }\end{array}$ & & $8 \mathrm{hr}$ recharging time \\
\hline
\end{tabular}

Source: Plug-In Vehicle Activities Summary, October 2010.

\section{Several possibilities exist to reduce heavy-truck engine idling}

Idle reduction is a worthy goal for all heavy-truck operators and fleet managers: It reduces fuel consumption and increases savings. The medium by which idle reduction is achieved is ultimately the decision of the operator or fleet manager. Some fleets may opt to pursue auxiliary power-unit technology, which consists of a small auxiliary engine used to provide climate control and electrical power for the sleeper cab and engine block heater when the vehicle is parked. Other may pursue other solutions, such as those promoted by IdleAire or Shorepower Technologies, both of which were discussed in more detail earlier.

An integrated electric hybrid solution probably holds the most promise for idle reduction in the long term. The speed at which heavy trucks progress toward that solution will be most directly affected by fuel prices and government regulations. 


\section{Seven railroads are considered Class I Railroads}

A railroad is designated as a Class I Railroad based on its operating revenue. To be a Class I Railroad in 2008, operating revenue must be $\$ 401.4$ million or more. This threshold is adjusted for inflation annually. There are currently seven Class I Railroads (Table 49), all of which greatly exceed the minimum operating revenue criteria for Class I (Figure 43). The active rail network by company is shown in Figure 44. There are 94,209 road miles in the Class I railroad mileage, not including parallel tracks at sidings and yards.

Table 49. List of Class I Railroads

\begin{tabular}{|l|l|}
\hline \multicolumn{1}{|c|}{ Name } & \multicolumn{1}{|c|}{ Acronym } \\
\hline BNSF Railway Company & BNSF \\
\hline Union Pacific Railroad Company & UP \\
\hline Norfolk Southern Railway Company & NS \\
\hline CSX Transportation, Inc. & CSX \\
\hline Grand Trunk Corporation & CNGT \\
\hline Kansas City Southern Railway Company & KCS \\
\hline Soo Line Railroad Company & SOO \\
\hline
\end{tabular}

Source: American Association of Railroads. Railroad Facts, 2008. Washington, DC. 2009.

Figure 43. Operating Revenue for Class I Railroads, 2008

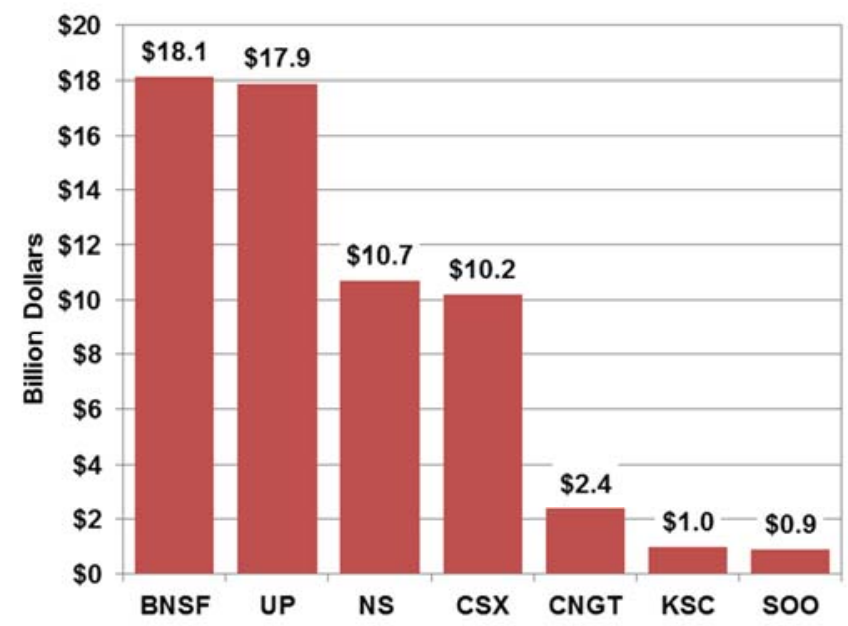

Source: American Association of Railroads. Railroad Facts, 2008. Washington, DC. 2009.
Figure 44. Rail Network by Company

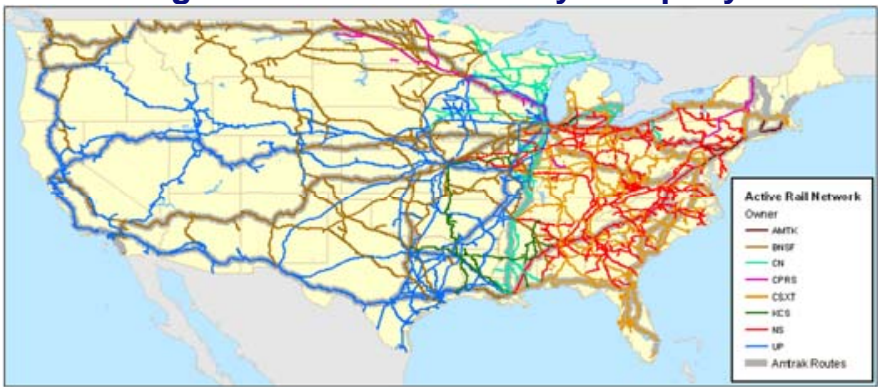

Source: ORNL Rail Network Database.

\section{Locomotive manufacturers have a long history}

There are two American manufacturers of locomotives: Electo-Motive Diesel and General Electric Transportation. Both manufacturers have been selling locomotives for more than 80 years and currently sell their products worldwide. The demand for new locomotive units varies from year to year; Figure 45 shows the historical trend of new locomotive installations going back to 1955 . In the last five years, new locomotive installations have been about $4 \%$ of the total locomotive population; about 24,000 locomotives were in service in 2008.

\section{Figure 45. New Locomotive Units for Class I Railroads}

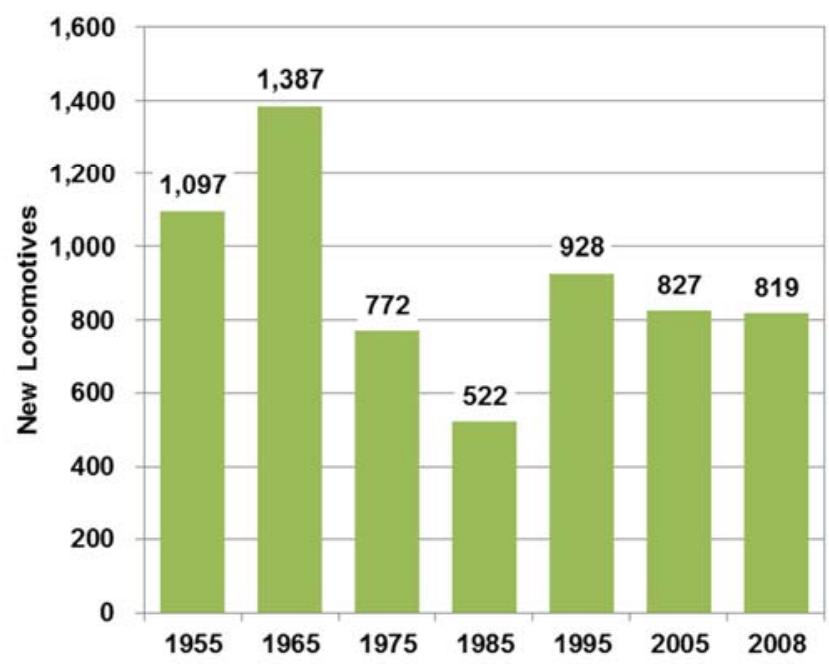

Source: American Association of Railroads. Analysis of Class I Railroads, 2008. Washington, DC. 2009. 


\section{Old locomotives are still in service}

There are about 24,000 locomotives in service. Many of the locomotives on the tracks today are more than 20 years old; thirty-percent of all locomotives in service in 2008 were built before 1985 (Figure 46). Sixteen percent of all locomotives were manufactured are 1-4 years old.

Figure 46. Locomotives in Service in 2008 by Date of Manufacture

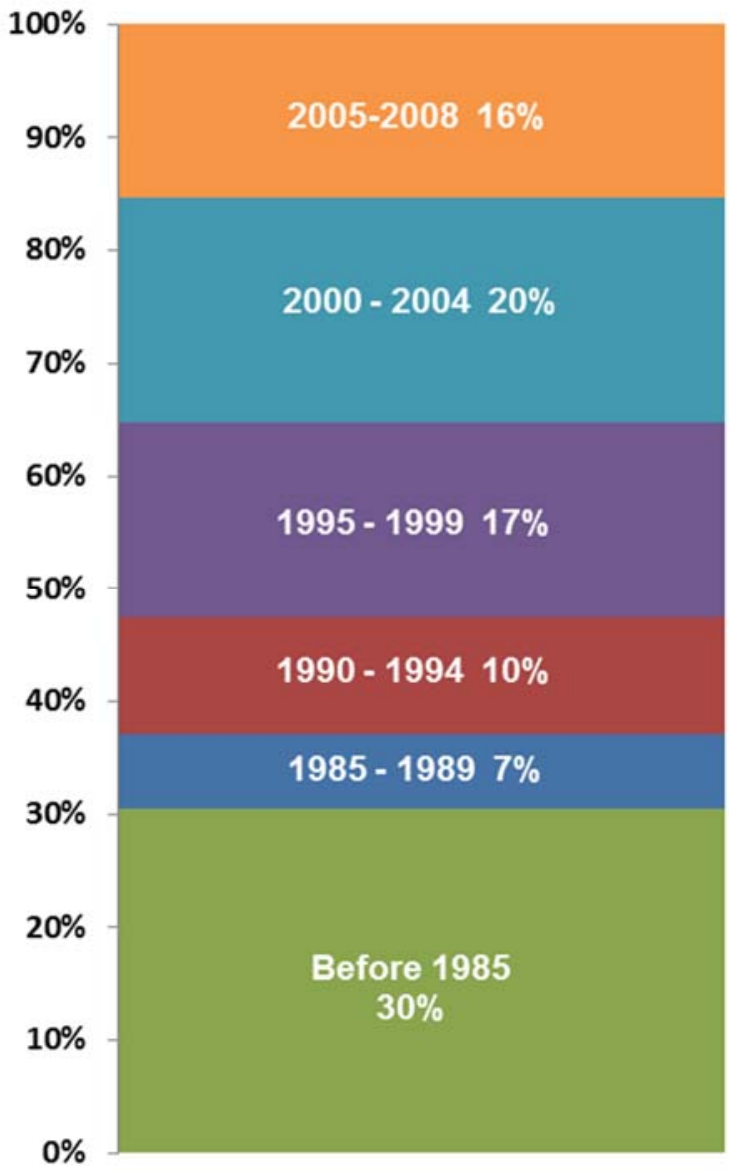

Source: American Association of Railroads. Railroad Facts, 2008. Washington, DC. 2009.

\section{New locomotives on the tracks}

In 2008, there were a total of 819 new dieselelectric locomotives installed into service, mainly by BNSF, UP and CSX (Table 50). A total of 143 rebuilt locomotives were installed by UP and NS. The locomotives in the "Other" category include mostly "slugs" (with traction motors to assist locomotives, but no motive power) and some battery-powered switching locomotives. There were 129 rebuilt locomotives installed in 2008, with BNSF and SOO accounting for the majority of those.
Table 50. Locomotives Installed into Service, 2008

\begin{tabular}{|l|r|r|r|}
\hline \multicolumn{4}{|c|}{ New Locomotives Installed } \\
\hline & $\begin{array}{c}\text { Diesel- } \\
\text { Electric }\end{array}$ & Other & Total \\
\hline BNSF & 382 & 0 & 382 \\
\hline UP & 179 & 0 & 179 \\
\hline NS & 40 & 0 & 40 \\
\hline CSX & 181 & 35 & 216 \\
\hline CNGT & 0 & 0 & 0 \\
\hline KCS & 37 & 0 & 37 \\
\hline SOO & 0 & 0 & 0 \\
\hline Total & $\mathbf{8 1 9}$ & $\mathbf{3 5}$ & $\mathbf{8 5 4}$ \\
\hline
\end{tabular}

Rebuilt Locomotives Installed

\begin{tabular}{|l|r|r|r|}
\hline BNSF & 0 & 0 & 0 \\
\hline UP & 103 & 0 & 103 \\
\hline NS & 26 & 14 & 40 \\
\hline CSX & 0 & 0 & 0 \\
\hline CNGT & 0 & 0 & 0 \\
\hline KCS & 0 & 0 & 0 \\
\hline SOO & 0 & 0 & 0 \\
\hline Total & $\mathbf{1 2 9}$ & $\mathbf{1 4}$ & $\mathbf{1 4 3}$ \\
\hline
\end{tabular}

Other/Used Locomotives Installed

\begin{tabular}{|l|r|r|r|}
\hline BNSF & 28 & 39 & 67 \\
\hline UP & 3 & 0 & 3 \\
\hline NS & 2 & 0 & 2 \\
\hline CSX & 2 & 0 & 2 \\
\hline CNGT & 1 & 0 & 1 \\
\hline KCS & 0 & 0 & 0 \\
\hline SO0 & 54 & 0 & 54 \\
\hline Total & 90 & $\mathbf{3 9}$ & $\mathbf{1 2 9}$ \\
\hline
\end{tabular}

Source: American Association of Railroads. Analysis of Class Railroads, 2008. Washington, DC. 2009.

\section{Covered hoppers and tank cars carry the goods}

Railroad equipment not only includes locomotives, but freight cars as well. Though the population of locomotives has been fairly stable over the past five years, the number of freight cars in service has grown by $8 \%$ (Table 51 ). In $2008,30 \%$ of the freight cars were covered hoppers, and another $20 \%$ were tank cars. Plain boxcars and refrigerated cars were on the decline from 2004 to 2008. The types of cargo carried by each freight car type are listed in Table 52. 
Table 51. Railroad Equipment (Thousands)

\begin{tabular}{|c|c|c|c|c|c|c|}
\hline & 2004 & 2005 & 2006 & 2007 & 2008 & $\begin{array}{c}2008 \\
\text { Freight Car } \\
\text { Share }\end{array}$ \\
\hline Locomotives in Service & 22 & 23 & 24 & 24 & 24 & \\
\hline Freight Cars in Service & 1,288 & 1,317 & 1,361 & 1,386 & 1,393 & $100 \%$ \\
\hline Boxcar - Plain & 19 & 20 & 20 & 16 & 16 & $1 \%$ \\
\hline Boxcar - Equipped & 115 & 114 & 113 & 105 & 99 & $7 \%$ \\
\hline Covered Hoppers & 378 & 383 & 398 & 412 & 415 & $30 \%$ \\
\hline Hoppers & 143 & 151 & 162 & 167 & 168 & $12 \%$ \\
\hline Flat cars & 159 & 169 & 174 & 172 & 170 & $12 \%$ \\
\hline Refrigerator cars & 24 & 24 & 23 & 22 & 19 & $1 \%$ \\
\hline Gondolas & 201 & 202 & 209 & 218 & 220 & $16 \%$ \\
\hline Tank Cars & 244 & 249 & 257 & 269 & 281 & $20 \%$ \\
\hline Others & 5 & 5 & 5 & 5 & 5 & $0 \%$ \\
\hline
\end{tabular}

Sources: American Association of Railroads. Railroad Facts, 2008. Washington, DC. 2009. and the four previous editions of Railroad Facts.

\begin{tabular}{|c|c|}
\hline Boxcar - Plain & $\begin{array}{l}\text { General commodities or mixed freight with } \\
\text { protection from weather and theft. }\end{array}$ \\
\hline $\begin{array}{l}\text { Boxcar - } \\
\text { Equipped }\end{array}$ & $\begin{array}{l}\text { Same as other boxcars, but equipped with } \\
\text { permanent racks for carrying a specific } \\
\text { commodity or equipped with a loading } \\
\text { device. }\end{array}$ \\
\hline $\begin{array}{l}\text { Covered } \\
\text { Hoppers }\end{array}$ & $\begin{array}{l}\text { Dry bulk commodities, such as grain, } \\
\text { fertilizer, cement, and sand. }\end{array}$ \\
\hline Hoppers & $\begin{array}{l}\text { Bulk commodities, such as coal, ore, and } \\
\text { grain. Hoppers discharge cargo on the } \\
\text { underside of the car. }\end{array}$ \\
\hline Flat cars & $\begin{array}{l}\text { Larger objects, such as heavy machinery } \\
\text { and pipes. Some flat cars carry intermodal } \\
\text { trailers or containers. }\end{array}$ \\
\hline $\begin{array}{l}\text { Refrigerator } \\
\text { cars }\end{array}$ & Perishable foodstuffs. \\
\hline Gondolas & $\begin{array}{l}\text { Loose bulk commodities, such as scrap } \\
\text { metal and construction material. }\end{array}$ \\
\hline Tank Cars & $\begin{array}{l}\text { Liquids and gases, such as petroleum, } \\
\text { solvents, food products, and chemicals. }\end{array}$ \\
\hline Others & $\begin{array}{l}\text { There are many other types of freight cars } \\
\text { that are specialized for a commodity, such } \\
\text { as automobiles cars, livestock cars, and } \\
\text { wood chip cars. }\end{array}$ \\
\hline
\end{tabular}

\section{Average cost of a new freight car is $\$ 95,000$}

The average cost of a new freight car in 2004 was $\$ 82,000$ (in real 2008 dollars), but that average rose to $\$ 95,000$ in 2008 (Figure 47). The average can change significantly from year to year due to the types of freight cars purchased in that year and how much specialization is required. A special service flat car costs about $\$ 224,000$, while a gondola costs $\$ 75,000$.

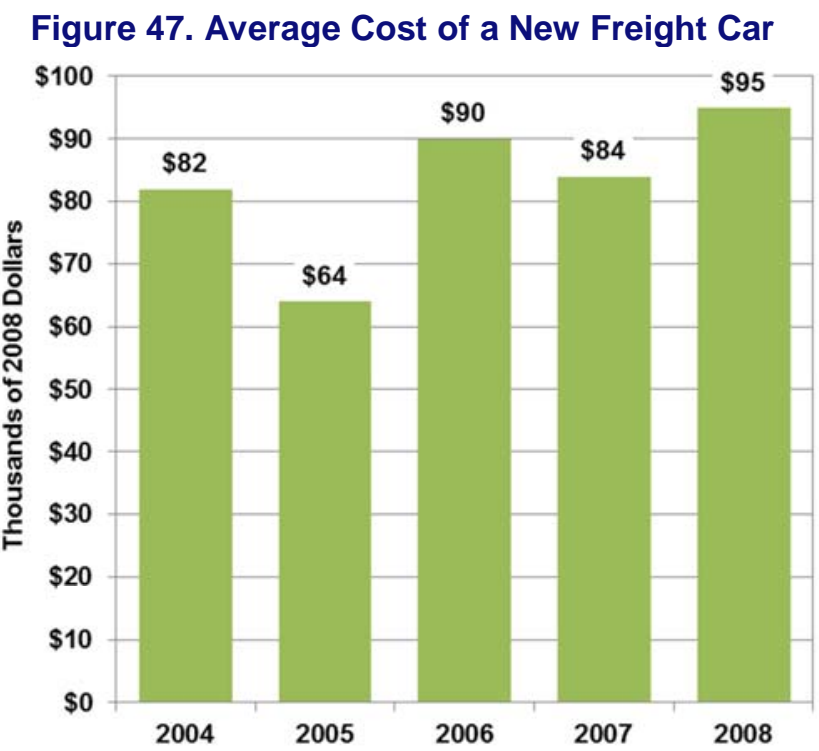

Source: American Association of Railroads. Railroad Facts, 2008. Washington, DC. 2009. 


\section{Railroad fuel efficiency is improving}

The efficiency of a locomotive engine depends on many variables, such as the weight of the freight cars, length of the train, and slope of the terrain. A good measure for railroad efficiency is the number of revenue ton-miles per gallon of fuel that is consumed. Since 2004, that measure has grown from 410 to 457 - an $11 \%$ improvement (Figure 48).

Figure 48. Trend of Revenue Ton-Miles per Gallon of Fuel Consumed

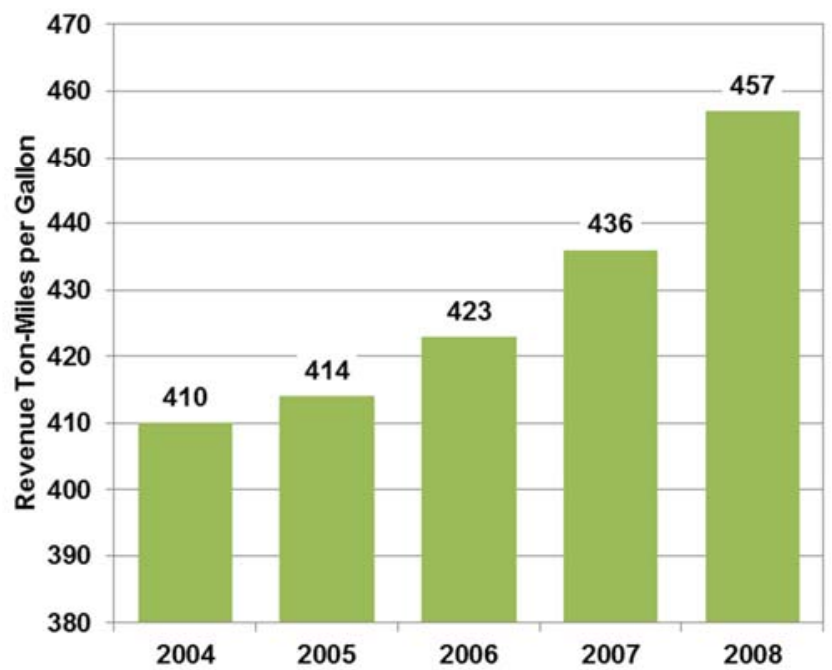

Source: American Association of Railroads. Railroad Facts, 2008. Washington, DC. 2009.

On a company basis, CNGT has the highest efficiency in 2008, with 532 revenue ton-miles per gallon (Figure 49). The other Class I Railroads have efficiencies between 450 and 500 revenue ton-miles per gallon, with the exception of NS, with 405.

\section{Figure 49. Revenue Ton-Miles per Gallon of Fuel Consumed, 2008}

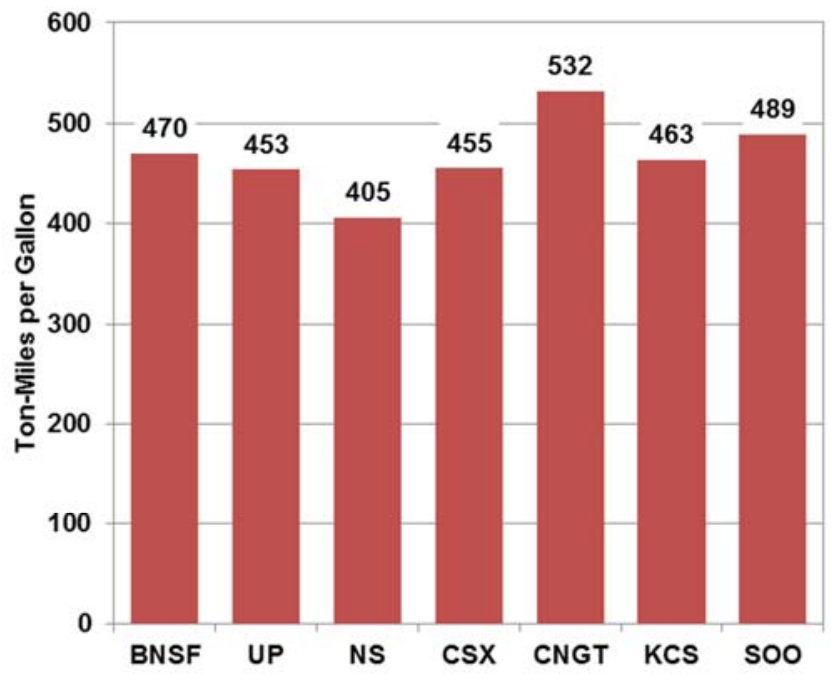

Source: American Association of Railroads. Analysis of Class I Railroads, 2008. Washington, DC. 2009.

\section{Ultralow sulfur diesel makes a difference}

The Clean Air Rules of 2004 limited sulfur in nonroad diesel fuel to a maximum of 500 parts per million (ppm) by 2007 and 15 ppm by 2010 - a $97 \%$ reduction. The ULSD allows engine manufacturers to use advanced emission-control systems that reduce both $\mathrm{PM}$ and $\mathrm{NO}_{\mathrm{x}}$, similar to those for heavy-duty diesel trucks.

\section{Tier 3 and Tier 4 Locomotive emission standards are set}

Once a locomotive is worn out or in disrepair, it is often more cost effective to rebuild the locomotive than it is to purchase a new replacement. When the locomotive engines are rebuilt they are typically upgraded to include newer engine technology. Thus, when EPA set emission standards for locomotives, they were set not only for locomotives produced in the future, but also for rebuilds of locomotives that were already manufactured. The most recent regulation of locomotive emissions was in 2008. The older model years have less strict standards than the newer model years.

Tier 0-2 standards for criteria pollutants were strengthened for existing locomotives and new near term (Tier 3) and long-term (Tier 4) standards were set. The regulated pollutants include hydrocarbons $(\mathrm{HC}), \mathrm{CO}, \mathrm{NO}_{\mathrm{X}}$, and PM. Tables 53 and 54 contain a summary of the standards for line-haul locomotives and switch locomotives. Older locomotives that are remanufactured after 2010 must be upgraded to meet the Tier 0-2 standards, depending on the model year of the locomotive. It is expected that Tier 4 standards will be met with the use of exhaust gas aftertreatment technologies.

The standards address line-haul and switch locomotives separately. Line-haul locomotives have powerful engines to carry many rail cars over a long distance. Switch locomotives assemble and disassemble trains in a train yard, thus they are typically low-powered but have a high starting tractive effort for getting heavy cars rolling quickly.

\section{Rail accounts for less than $3 \%$ of transportation greenhouse gas emissions}

According to EPA, rail accounted for about 51 MMT of $\mathrm{CO}_{2}$ equivalents in 2008, down from 53.0 MMT three years earlier (Table 55). Most of the greenhouse gas emissions are $\mathrm{CO} 2$, but small amounts of methane (CH4), nitrous oxide (N20), hydrofluorocarbon (HFCs), and other gases are also emitted from rail operations. In terms of total transportation sector greenhouse gas emissions, rail is only responsible for $2.7 \%$. 
Table 53. Emission Standards for Line-Haul Locomotives That are Manufactured or Remanufactured after the Effective Date (Grams per Brake Horsepower-Hour)

\begin{tabular}{|c|c|c|c|c|c|c|}
\hline Tier & MY & $\begin{array}{c}\text { Effective } \\
\text { Date }\end{array}$ & HC & CO & NOx & PM \\
\hline Tier 0 $^{\mathbf{a}}$ & $1973-1992^{\mathrm{c}}$ & 2010 & 1 & 5 & 8 & 0.22 \\
\hline Tier 1 $^{\mathbf{a}}$ & $1993^{\mathrm{c}}-2004$ & 2010 & 0.55 & 2.2 & 7.4 & 0.22 \\
\hline Tier 2 $^{\mathbf{a}}$ & $2005-2011$ & 2010 & 0.3 & 1.5 & 5.5 & $0.10^{\mathrm{d}}$ \\
\hline Tier 3 $^{\mathbf{b}}$ & $2012-2014$ & 2012 & 0.3 & 1.5 & 5.5 & 0.1 \\
\hline Tier 4 & 2015 or later & 2015 & $0.14 \mathrm{e}$ & 1.5 & $1.3^{\mathrm{e}}$ & 0.03 \\
\hline
\end{tabular}

a - Tier 0-2 line-haul locomotives must also meet switch standards of the same tier.

b - Tier 3 line-haul locomotives must also meet Tier 2 switch standards.

c-1993-2001 locomotive that were not equipped with an intake air coolant system are subject to Tier 0 rather than Tier 1 standards.

d - $0.20 \mathrm{~g} / \mathrm{bhp}$-hr until January 1, 2013 (with some exceptions).

e - Manufacturers may elect to meet a combined NOx+HC standard of $1.4 \mathrm{~g} / \mathrm{bhp}-\mathrm{hr}$.

Source: DieselNet, http://www.dieselnet.com/standards/us/loco.php.

Table 54. Emission Standards for Switch Locomotives That are Manufactured or Remanufactured after the Effective Date (Grams per Brake Horsepower-Hour)

\begin{tabular}{|c|c|c|c|c|c|c|}
\hline Tier & MY & $\begin{array}{c}\text { Effective } \\
\text { Date }\end{array}$ & HC & CO & NOx & PM \\
\hline Tier 0 & $1973-2001$ & 2010 & 2.1 & 8 & 11.8 & 0.26 \\
\hline Tier 1a & $2002-2004$ & 2010 & 1.2 & 2.5 & 11 & 0.26 \\
\hline Tier 2 $^{\mathbf{a}}$ & $2005-2010$ & 2010 & 0.6 & 2.4 & 8.1 & $0.13^{\mathrm{b}}$ \\
\hline Tier 3 & $2011-2014$ & 2011 & 0.6 & 2.4 & 5 & 0.1 \\
\hline Tier 4 & 2015 or later & 2015 & $0.14^{\mathrm{c}}$ & 2.4 & $1.3^{\mathrm{c}}$ & 0.03 \\
\hline
\end{tabular}

a - Tier 1-2 switch locomotives must also meet line-haul standards of the same tier.

b - 0.24 g/bhp-hr until January 1, 2013 (with some exceptions).

c - Manufacturers may elect to meet a combined NOx+HC standard of $1.3 \mathrm{~g} / \mathrm{bhp}-\mathrm{hr}$.

Source: DieselNet, http://www.dieselnet.com/standards/us/loco.php.

Table 55. Rail Greenhouse Gas Emissions (MMT of CO2 Equivalents)

\begin{tabular}{|c|c|c|c|c|}
\hline 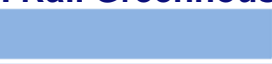 & 2005 & 2006 & 2007 & 2008 \\
\hline $\mathrm{CO} 2$ & 50.3 & 52.4 & 51.6 & 47.9 \\
\hline CH4 & 0.1 & 0.1 & 0.1 & 0.1 \\
\hline $\mathrm{N} 20$ & 0.4 & 0.4 & 0.4 & 0.4 \\
\hline HFCs & 2.2 & 2.2 & 2.2 & 2.3 \\
\hline Other & 0.1 & 0.1 & 0.1 & 0.1 \\
\hline Total Rail & 53.0 & 55.1 & 54.3 & 50.6 \\
\hline $\begin{array}{l}\text { Total } \\
\text { Transportation }\end{array}$ & $2,020.9$ & $1,997.6$ & $2,008.6$ & $1,890.8$ \\
\hline $\begin{array}{l}\text { Rail Share of } \\
\text { Total } \\
\text { Transportation }\end{array}$ & $2.6 \%$ & $2.8 \%$ & $2.7 \%$ & $2.7 \%$ \\
\hline
\end{tabular}

Source: U.S. EPA, Inventory of U.S. Greenhouse Gas Emissions and Sinks, 1990-2008, April 2010. 


\section{Future technologies for locomotives}

Hybrid diesel-electric locomotives are being developed that will capture the energy dissipated during braking and store it for future use. This has the potential to reduce fuel consumption by up to $15 \%$ and emissions by $50 \%$ compared to most locomotives currently in use. In addition, the hybrid will operate more efficiently in higher altitudes and up steep inclines.

Automatic engine start/stop technologies are also being developed that can reduce engine idle time, thus reduce fuel use and emissions.

\section{Deregulation of the railroad industry has been successful}

The Staggers Act of 1980 removed many regulatory restraints on the railroad industry, thus providing the rail companies increased pricing flexibility while still protecting the shippers. This balanced regulation has helped the rail industry to gain financial health, gain market share, and increase productivity, all while rates have declined (55\% decline from 1981 to 2009, according to the American Association of Railroads).

\section{Traffic density has increased for most Class I Railroads}

BNSF and KSC had the largest increases in traffic density from 2004 to 2008, which is measured as million revenue ton-miles per owned mile of road (Figure 50). Traffic density is an indicator of the utilization of the railroad infrastructure. A higher traffic density means greater utilization efficiency. In 2008, BNSF and UP had the highest traffic densities, followed by the SOO, one of the smallest Class I railroads.

Figure 50. Traffic Density for Class I Railroads

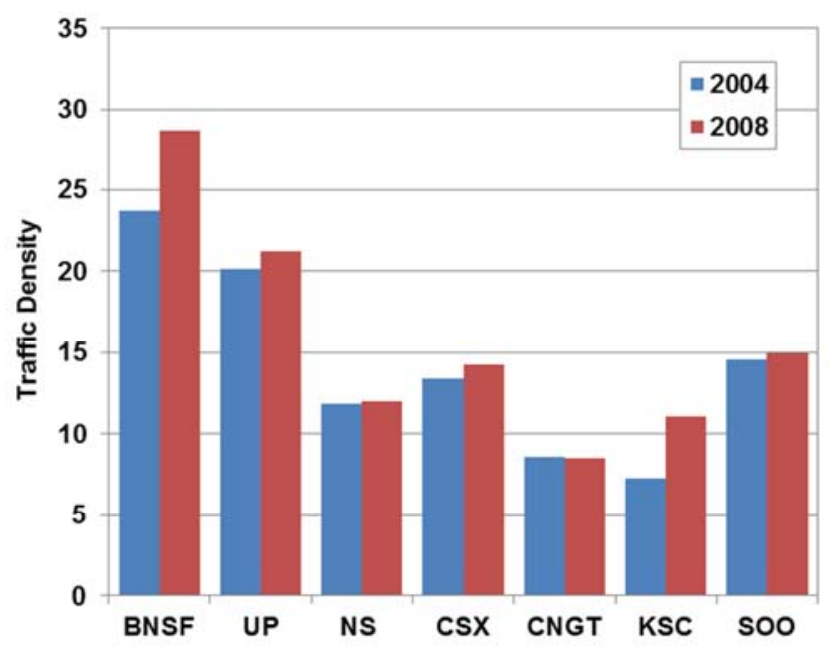

Note: Traffic Density = Million revenue ton-miles per owned mile of road.

Source: American Association of Railroads. Railroad Facts, 2008. Washington, DC. 2009. American Association of Railroads. Railroad Facts, 2004. Washington, DC. 2005.
Average railcar capacity is expanding

There are many different types of railcars which are designed to haul the various products moved by rail. The railcar with the highest capacity is the Flat TOFC/COFC; due to the ability to double stack the trailers/containers on the railcar, the capacity is nearly double that of any other rail car type (See Table 56). Gondola and hopper cars all average above 100 tons per car, while boxcars, refrigerator cars, and other types typically hold less. The average capacity for all cars has increased significantly over the last 50 years (Figure 51).

Table 56. Average Capacity Per Rail Car, 2008 (Tons)

\begin{tabular}{|l|r|}
\hline Box - Plain 40' & 60 \\
\hline Box - Plain 50 ' & 95 \\
\hline Box - Equipped & 83 \\
\hline Gondola - Plain & 115 \\
\hline Gondola - Equipped & 101 \\
\hline Covered Hopper & 106 \\
\hline Open Hopper - General Service & 104 \\
\hline Open Hopper - Special Service & 106 \\
\hline Refrigerator - Mechanical & 81 \\
\hline Refrigerator - Non-Mechanical & 79 \\
\hline Flat TOFC/COFC* & 223 \\
\hline Flat Multi-Level & 39 \\
\hline Flat General Service & 77 \\
\hline Flat All Other & 97 \\
\hline All Other Types & 59 \\
\hline Average Freight Car Capacity & 100 \\
\hline * TOFC = trailer on flatcar. & \\
\hline COFC = container on flatcar & \\
\hline
\end{tabular}

Source: American Association of Railroads. Analysis of Class I Railroads, 2008. Washington, DC. 2009.

Figure 51. Average Freight Car Capacity per Rail Car

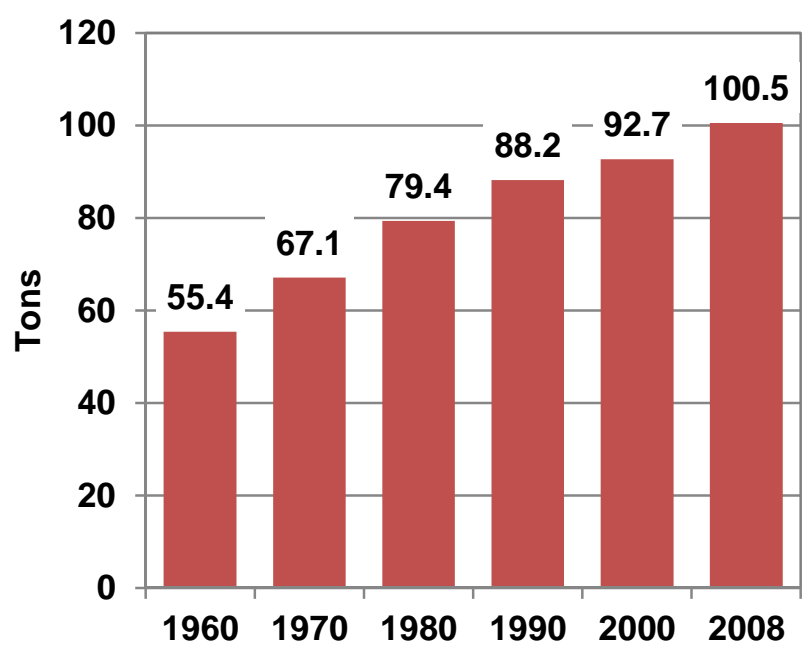

Source: American Association of Railroads. Railroad Facts, 2008. Washington, DC. 2009. 


\section{Productivity of Class I Railroads is at an all-time high}

Productivity, measured as revenue ton-miles per employee-hour, has increased $10 \%$ over the last five years (Table 57). Impressive as that is, data show that the productivity rate in 2008 is five times that in 1980 when deregulation of the freight railroad industry was first enacted.

\section{Table 57: Productivity Rates}

\begin{tabular}{|c|c|c|}
\hline $\mathbf{2}$ & $\begin{array}{c}\text { Revenue } \\
\text { Ton-miles } \\
\text { per } \\
\text { Employee }\end{array}$ & $\begin{array}{c}\text { Revenue Ton- } \\
\text { Miles per } \\
\text { Employee-Hour }\end{array}$ \\
\hline $\mathbf{1 9 8 0}$ & 2.1 & 863 \\
\hline & Deregulation in & $\mathbf{1 9 8 0}$ \\
\hline $\mathbf{2 0 0 4}$ & 10.6 & 3,908 \\
\hline $\mathbf{2 0 0 5}$ & 10.5 & 4,019 \\
\hline $\mathbf{2 0 0 6}$ & 10.6 & 4,059 \\
\hline $\mathbf{2 0 0 7}$ & 10.6 & 4,182 \\
\hline $\mathbf{2 0 0 8}$ & 10.8 & 4,307 \\
\hline
\end{tabular}

Source: American Association of Railroads. Railroad Facts, 2008. Washington, DC. 2009.

\section{Summary}

The economic downturn in 2008 and 2009 affected the transportation sector. Declines in energy use, vehicle sales, and vehicle-miles of travel were experienced during this period, along with volatility of fuel prices. Despite this, new engine and vehicle technologies are entering the market. Alternative fuels and cleaner fuels are also becoming more readily available. Railroad locomotives and freight cars are advancing too.

In the coming years, the new technologies will help the transportation sector to become more efficient in the movement of people and goods. 
This page intentionally left blank. 


\section{Key Program Contacts}

Patrick Davis, Program Manager Vehicle Technologies Program Office of Energy Efficiency and Renewable Energy U.S. Department of Energy 1000 Independence Ave, SW Washington, DC 20585

Ken Howden, Director 21st Century Truck Partnership Vehicle Technologies Program Office of Energy Efficiency and Renewable Energy

U.S. Department of Energy 1000 Independence Ave, SW Washington, DC 20585

Christy Cooper, Director FreedomCAR and Fuel Partnership Vehicle Technologies Program Office of Energy Efficiency and Renewable Energy

U.S. Department of Energy 1000 Independence Ave, SW Washington, DC 20585

Larry Johnson, Director Transportation Technology R\&D Center Argonne National Laboratory 9700 South Cass Avenue

Argonne, IL 60439

Barb Goodman, Center Director Center for Transportation Technologies and System s

National Renewable Energy Laboratory 1617 Cole Boulevard

Golden, Colorado 80401

Ron Graves, Director

Transportation Technology Program

National Transportation Research Center

User Facili ty

Oak Ridge National Laboratory

2360 Cherahala Blvd

Oak Ridge, TN 37932

Bob Carling, Director

Transportation Energy Center

Sandia National Laboratory

PO Box 969

Livermore, CA 94551

\section{Vehicle Technologies Web Sites}

\section{U.S. DEPARTMENT OF ENERGY VEHICLE TECHNOLOGIES PROGRAM http://www.eere.energy.gov/vehiclesandfuels/}

FACT OF THE WEEK

http://www1.eere.energy.gov/vehiclesandfuels/facts/

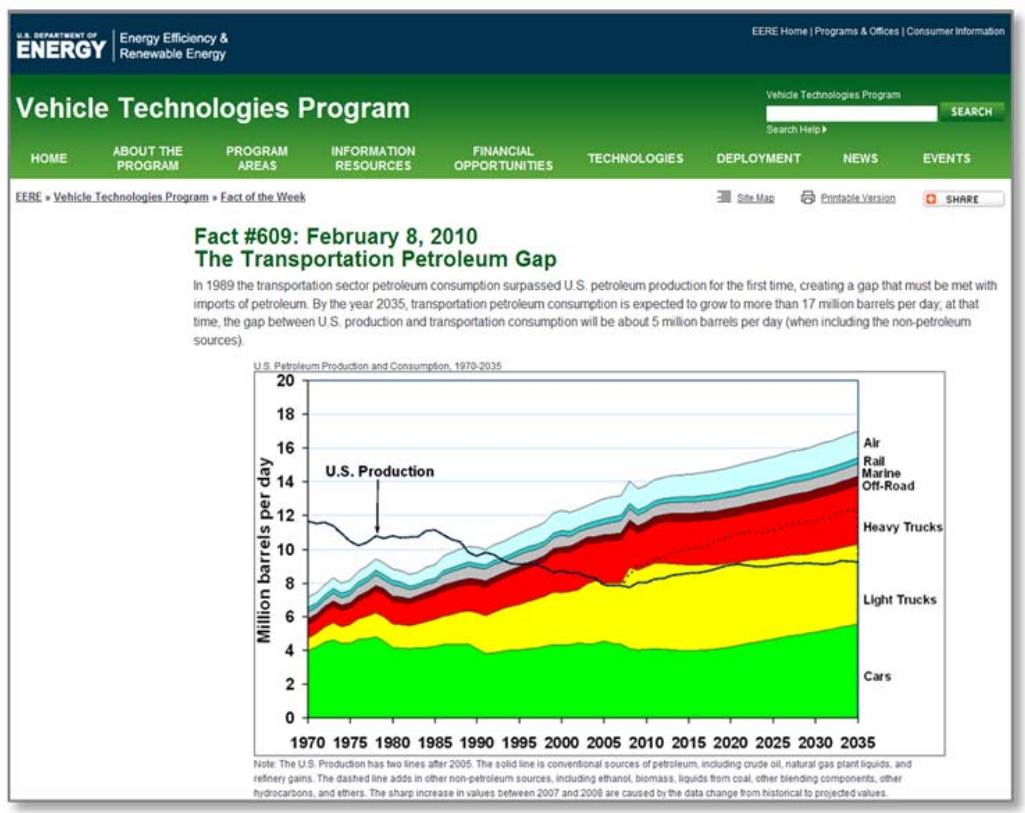

CLEAN CITIES PROGRAM

http://www1.eere.energy.gov/cleancities/

FUEL ECONOMY.GOV

http://fueleconomy.gov/

ALTERNATIVE FUELS AND ADVANCED VEHICLES DATA CENTER http://www.afdc.energy.gov/afdc/

\section{FREEDOMCAR AND FUEL PARTNERSHIP}

http://www.uscar.org/

\section{ST CENTURY TRUCK PARTNERSHIP}

http://www1.eere.energy.gov/vehiclesandfuels/about/partnerships/21centurytruck

TRANSPORTATION ENERGY DATA BOOK

http://cta.ornl.gov/data/

\section{Key Report Contacts}

For more information on this report, please contact:
Jake Ward, U.S. Department of Energy 202-586-7606; jacob.ward@ee.doe.gov
Stacy Davis, Oak Ridge National Laboratory 865-946-1256; davissc@ornl.gov
Prepared by ORNL, a national laboratory of the

U.S. Department of Energy, operated by

UT-Battelle, LLC.

ORNL/TM-2011/28863

March 2011
For more information contact:

EERE Information Center

1-877-EERE-INF (1-877-337-3463)

www.eere.energy.gov/informationcenter 